\title{
Projected Benefits of New Residential Evaporative Cooling Systems: Progress Report \#2
}

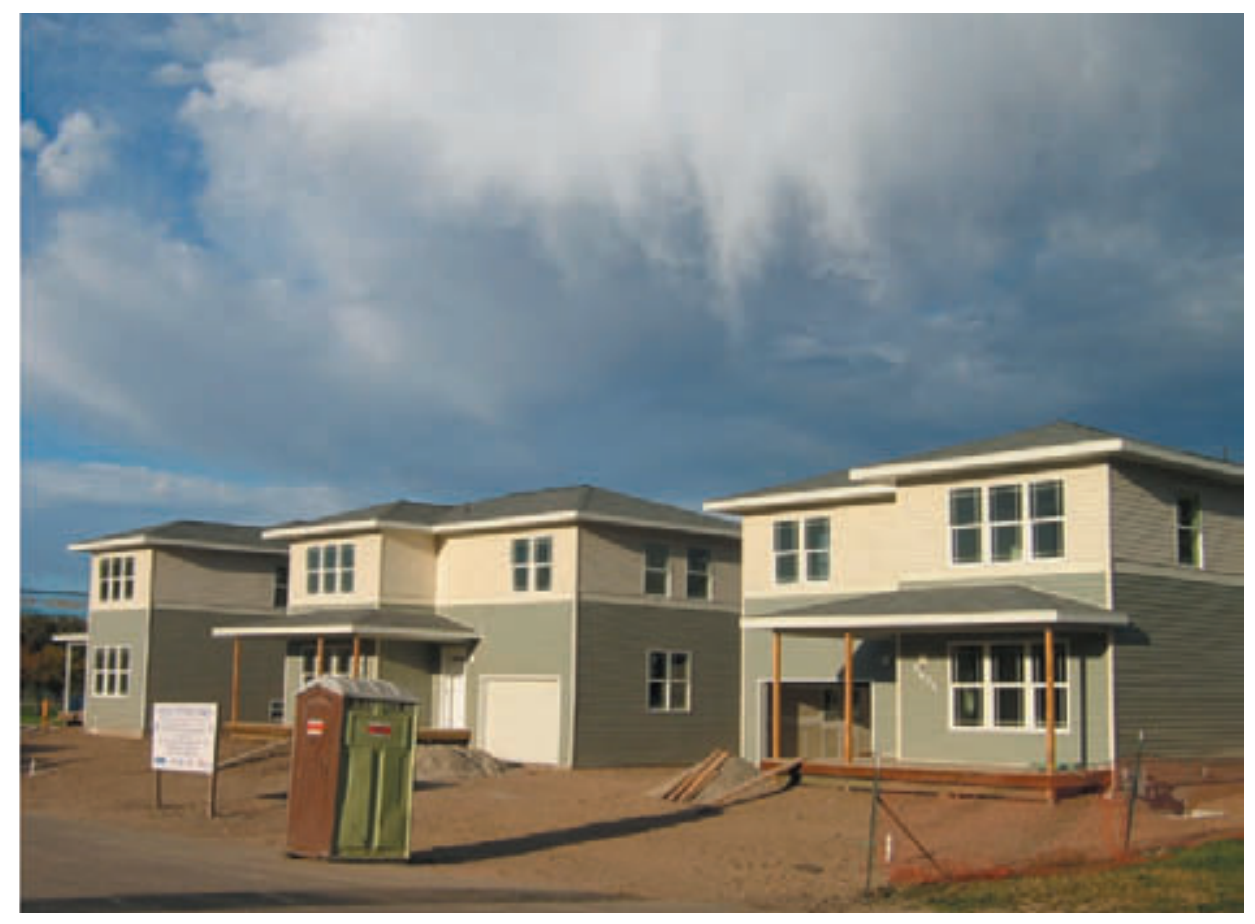

Chuck Kutscher and Mark Eastment National Renewable Energy Laboratory Golden, Colorado

\section{Ed Hancock}

Mountain Energy Partnership

Boulder, Colorado

\section{Paul Reeves}

Partnership for Resource Conservation

Golden, Colorado 


\section{Projected Benefits of New} Residential Evaporative Cooling Systems: Progress Report \#2

C. Kutscher and M. Eastment National Renewable Energy Laboratory Golden, Colorado

E. Hancock

Mountain Energy Partnership

Boulder, Colorado

P. Reeves

Partnership for Resource Conservation Golden, Colorado

Prepared under Task No.BET6.8004
Technical Report NREL/TP-550-39342

October 2006

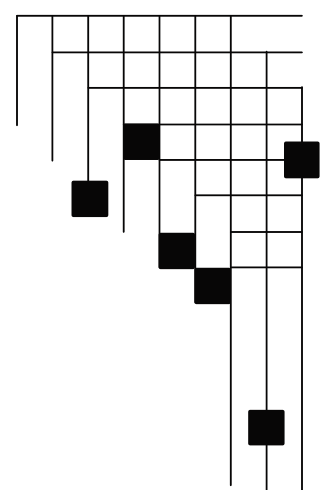




\section{NOTICE}

This report was prepared as an account of work sponsored by an agency of the United States government. Neither the United States government nor any agency thereof, nor any of their employees, makes any warranty, express or implied, or assumes any legal liability or responsibility for the accuracy, completeness, or usefulness of any information, apparatus, product, or process disclosed, or represents that its use would not infringe privately owned rights. Reference herein to any specific commercial product, process, or service by trade name, trademark, manufacturer, or otherwise does not necessarily constitute or imply its endorsement, recommendation, or favoring by the United States government or any agency thereof. The views and opinions of authors expressed herein do not necessarily state or reflect those of the United States government or any agency thereof.

Available electronically at http://www.osti.gov/bridge

Available for a processing fee to U.S. Department of Energy and its contractors, in paper, from:

U.S. Department of Energy

Office of Scientific and Technical Information

P.O. Box 62

Oak Ridge, TN 37831-0062

phone: 865.576 .8401

fax: 865.576 .5728

email: mailto:reports@adonis.osti.gov

Available for sale to the public, in paper, from:

U.S. Department of Commerce

National Technical Information Service

5285 Port Royal Road

Springfield, VA 22161

phone: 800.553.6847

fax: 703.605.6900

email: orders@ntis.fedworld.gov

online ordering: http://www.ntis.gov/ordering.htm 


\section{Table of Contents}

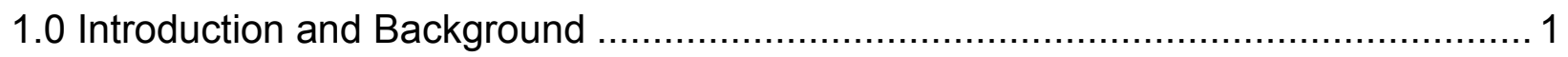

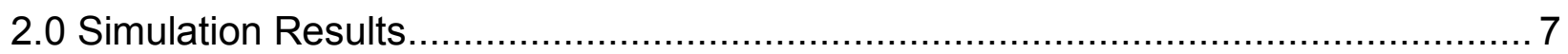

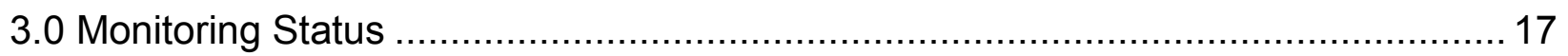

3.1 Borrego Springs Weather Station Specifications ............................................ 18

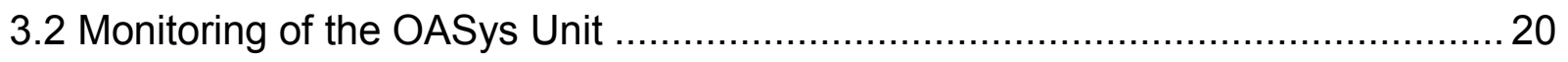

3.2.1 OASys Performance Data Results from Magna ........................................ 24

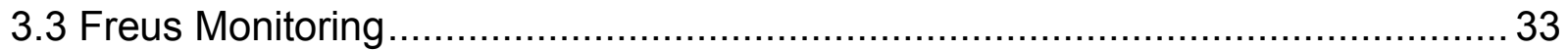

3.3.1 Monitoring Plans for Borrego Springs Freus Unit ..................................... 33

3.3.2 Freus Performance Data Results from Magna ............................................. 45

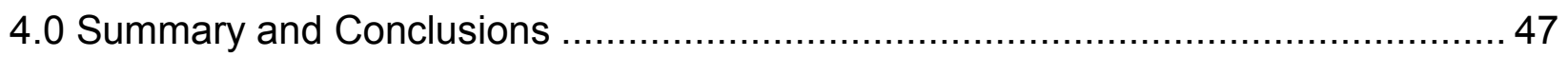

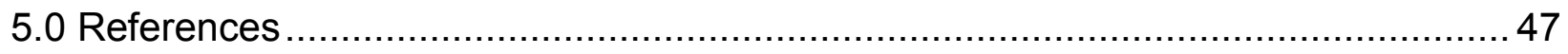

Appendix A. OASys Technical Specifications ….................................................. 48

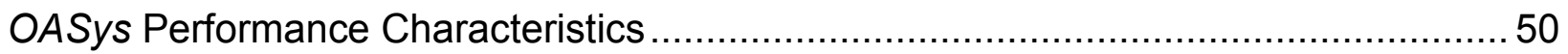




\section{List of Figures}

Figure 1. Schematic of OASys unit (E. Kozubal, National Renewable Energy

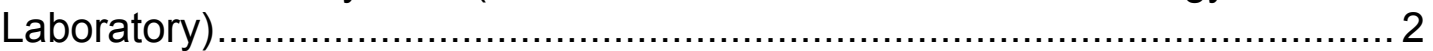

Figure 2. Schematic of Freus Components ........................................................ 3

Figure 3. Building America prototype homes at Magna, Utah ................................. 5

Figure 4. OASys unit installed at Magna Unit 1 .................................................... 6

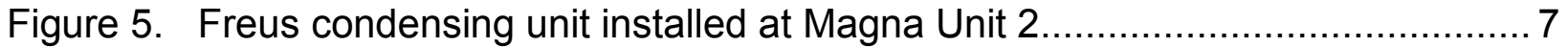

Figure 6. Common floor plan for Borrego Springs homes ...................................... 8

Figure 7. Distribution of hours when indoor temperature or humidity are too high for direct-evaporative cooler in Borrego Springs, California ........... 13

Figure 8. Distribution of hours when indoor temperature or humidity are too high for OASys unit in Borrego Springs, California.................................. 14

Figure 9. Distribution of hours when indoor temperature or humidity are too high for direct-evaporative cooler in Albuquerque, New Mexico ............ 14

Figure 10. Distribution of hours when indoor temperature or humidity are too high for OASys system in Albuquerque, New Mexico .......................... 15

Figure 11. Comparison of four cooling systems in various locations........................... 16

Figure 12. Comparison of fan energy use for cooling systems in various locations ...... 17

Figure 13. Supply plenum layout for Wagon OASys indirect/direct

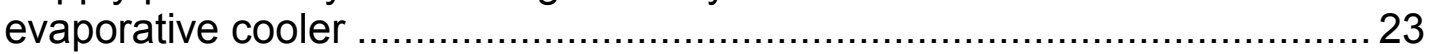

Figure 14. Outdoor conditions for Magna data-collection period.................................. 25

Figure 15. Indoor conditions for Magna data-collection period ................................ 26

Figure 16. Outdoor wet-bulb temperature comparison for Magna data-collection period.................................................................... 27

Figure 17. The EER values for OASys and OASys plus furnace $\mathrm{AH}$ fan ......................28

Figure 18. Energy use for OASys and OASys plus furnace AH fan .............................2 29

Figure 19. Wet-bulb effectiveness for the OASys unit at Magna................................ 30

Figure 20. Cooling delivered by the OASys unit at Magna........................................ 31

Figure 21. Performance during cool outdoor air temperatures................................. 32

Figure 22. Energy consumed by the OASys unit and furnace AH fan for early September

Figure 23. Pitot tube traverse airflow sensors installed at the return duct for the DiGiorgio home 
Figure 24. Illustration of the non-uniform return duct and close proximity of Pitot tube traverse airflow sensors to outdoor air damper and return register assembly.

Figure 25. Vaisala temperature and RH sensors (left in plate shield) and custom forced-aspiration radiation shield with thermocouples (right, white PVC) installed at fence surrounding Freus condensing unit.

Figure 26. Thermocouple (brown wire) and Vaisala temperature and RH sensors (white PVC shield + gray sensor) installed at Freus air intake, grill removed.

Figure 27. Thermocouple (brown wire) and sampling tube (white PVC shield plus white tube) installed at Freus exhaust grill. Vacuum pump housing shown on left (White PVC pipe fitting)

Figure 28. Fan-assisted flow hood installed on the Freus unit.

Figure 29. Measurements taken at Magna, Utah, showing the sensible, latent, and total cooling capacities of the Freus unit at two different fans speeds on August 10, 2005

\section{List of Tables}

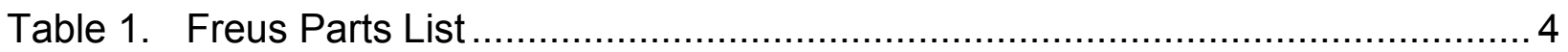

Table 2. DOE-2 Simulation Results for the Prototype House in Borrego Springs, California, using Different Cooling Systems

Table 3. DOE-2 Simulation Results for a Prototype House in Albuquerque, New Mexico, using Different Cooling systems .......................................... 12

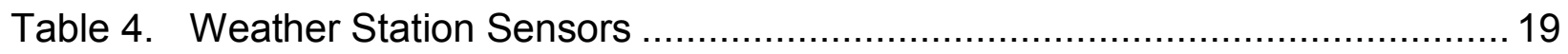

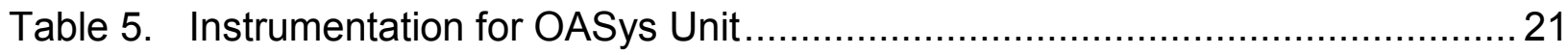

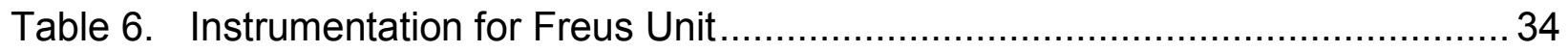

Table 7. Measurement Results for Freus Unit at Magna after Refrigerant was Added.... 


\section{Definitions}

\begin{tabular}{|c|c|}
\hline $\mathrm{AH}$ & air handler \\
\hline ARI capacity & American Refrigeration Institute \\
\hline BIRA & Building Industry Research Alliance \\
\hline CARB & Consortium for Advanced Residential Buildings \\
\hline CFL & compact fluorescent lighting \\
\hline CFM & cubic feet per minute \\
\hline CT & Current Transducer \\
\hline $\mathrm{db}$ & dry bulb \\
\hline $\mathrm{DEG}$ & Davis Energy Group \\
\hline DOE & U.S. Department of Energy \\
\hline DOE-2 & $\begin{array}{l}\text { Building energy analysis program that can predict the energy } \\
\text { use and cost for all types of buildings }\end{array}$ \\
\hline $\mathrm{DX}$ & direct expansion \\
\hline $\mathrm{ECC}$ & Evaporative Cooling Coil \\
\hline EER & energy efficiency ratio \\
\hline MNPT & Male, National Pipe Thread \\
\hline NPT & National Pipe Thread \\
\hline NREL & National Renewable Energy Laboratory \\
\hline OASys & an indirect/direct evaporative cooler \\
\hline $\mathrm{Pa}$ & Pascals \\
\hline PF & power factor \\
\hline $\mathrm{RH}$ & relative humidity \\
\hline RMS & Root Mean Square \\
\hline RTD & Resistance Temperature Device \\
\hline SEER & seasonal energy efficiency rating \\
\hline SIP & structural insulated panel \\
\hline SWA & Steven Winters Associates \\
\hline $\mathrm{wb}$ & wet bulb \\
\hline
\end{tabular}




\section{Projected Benefits of New Residential Evaporative Cooling Systems: Progress Report \#2}

\subsection{Introduction and Background}

The use of conventional evaporative cooling has rapidly declined in the United States despite the fact that it has high potential for energy savings in dry climates. Evaporative systems are very competitive in terms of first cost and provide significant reductions in operating energy use, as well as peak-load reduction benefits. Significant market barriers, such as the cost of the prototype evaporative cooling systems and consumer perceptions of evaporative coolers being unable to maintain comfort conditions, still remain and can be addressed through improved systems integration, including the following:

- Innovative components

- Better design of supply ducts and dampers

- Identification of best climates for full cooling season comfort control and potential limits imposed by a rainy season

- Development of utility partnerships to roll out evaporative cooling system design parameters for production builders.

This report investigates the first of these approaches, exploring innovative components. The U.S. Department of Energy (DOE) Building America research teams are investigating the use of two promising new pieces of residential cooling equipment that employ evaporative cooling as a part of their system design. The OASys unit shown in Figure 1, which is a combination of direct and indirect evaporative cooling stages developed by Davis Energy Group (DEG) and manufactured by Speakman CRS, is used to ultimately provide outside air to the living space. 


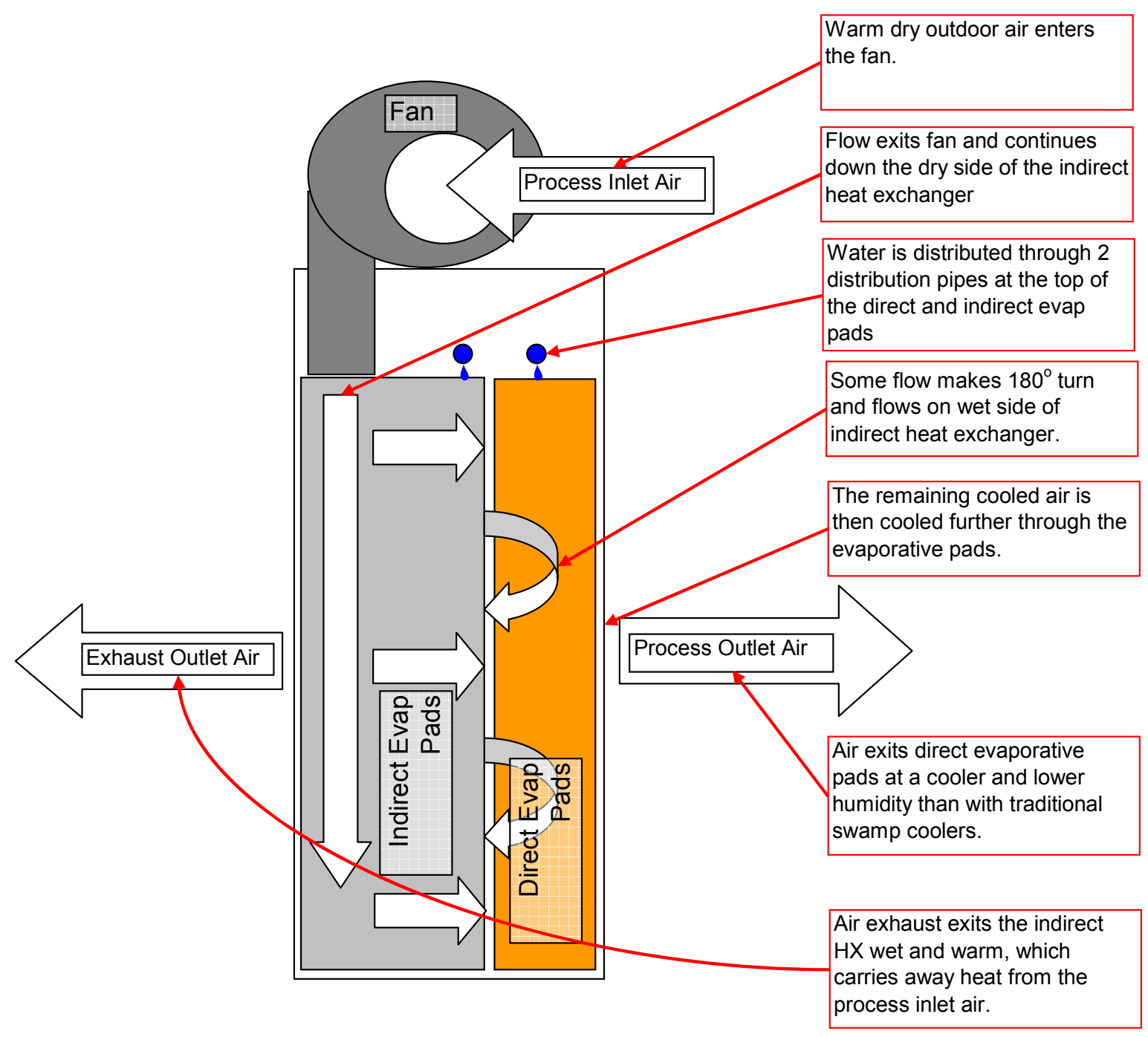

Figure 1. Schematic of OASys unit (E. Kozubal, National Renewable Energy Laboratory)

The outdoor air provided is indirectly and directly evaporatively cooled in two stages to a condition that can be below the wet-bulb (wb) temperature of the outside air, thus outperforming a conventional single-stage direct evaporative cooler.

The other concept, marketed by Freus, consists of an outdoor evaporative condenser coil that is wetted by water spray nozzles and matched to a conventional air-conditioning system as described in Figure 2 and Table 1. 


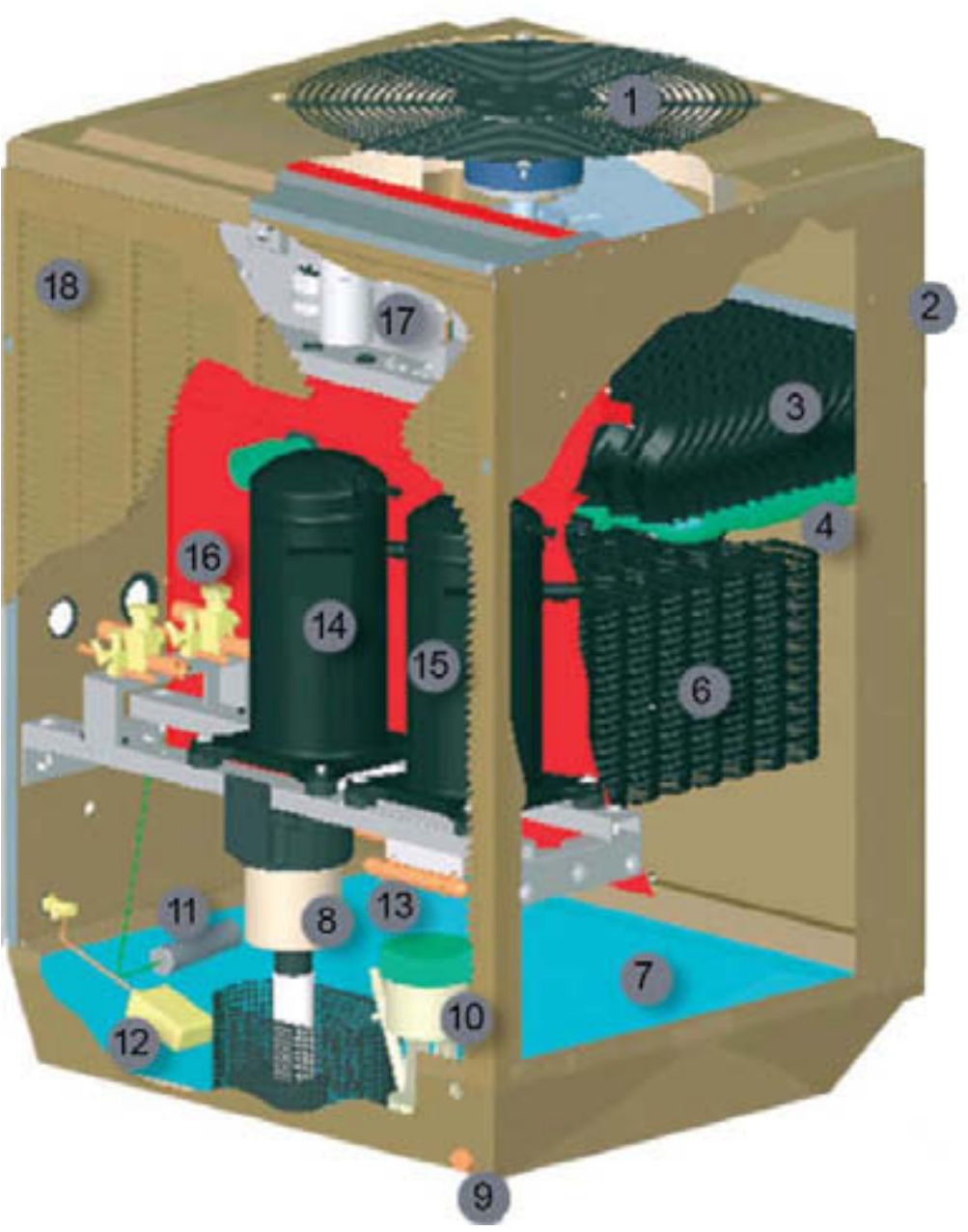

Figure 2. Schematic of Freus components 


\section{Table 1. Freus Parts List}

\begin{tabular}{|c|c|}
\hline Part Number & Description \\
\hline 1 & Fan grille \\
\hline 2 & Fiberglass cabinet \\
\hline 3 & Drift eliminator \\
\hline 4 & Distribution piping \\
\hline 5 & Low pressure $1 / 4$-in. spray nozzles (not shown) \\
\hline 6 & Helical condenser coil \\
\hline 7 & Sump \\
\hline 8 & Pump \\
\hline 9 & Drain \\
\hline 10 & Flush Pump \\
\hline 11 & $\begin{array}{l}\text { Magnesium anode - provides sacrificial corrosion } \\
\text { protection }\end{array}$ \\
\hline 12 & Float valve \\
\hline 13 & Refrigerant filter dryer \\
\hline 14 & Scroll compressor \\
\hline 15 & Additional compressor for multi-zone systems \\
\hline 16 & Service valves \\
\hline 17 & Electrical panel \\
\hline 18 & Louvered intake \\
\hline
\end{tabular}

The wetted condenser allows the refrigerant in the condenser coil to approach the outdoor-air wet-bulb temperature, as opposed to the higher outdoor-air dry-bulb $(\mathrm{db})$ temperature, thus allowing for higher energy efficiency ratios (EER). The Freus is designed to replace conventional air-cooled condensing units for new and retrofit applications.

These systems are being tested in two Building America prototype home locations: three homes built by the Community Development Corporation of Utah in Magna, Utah, and four homes built by Clarum homes in Borrego Springs, California. At Magna, Unit \#1 has three bedrooms and 2.5 baths and is 1,540 $\mathrm{ft}^{2}$ plus a $770-\mathrm{ft}^{2}$ basement and detached garage (leftmost home in Figure 3). 


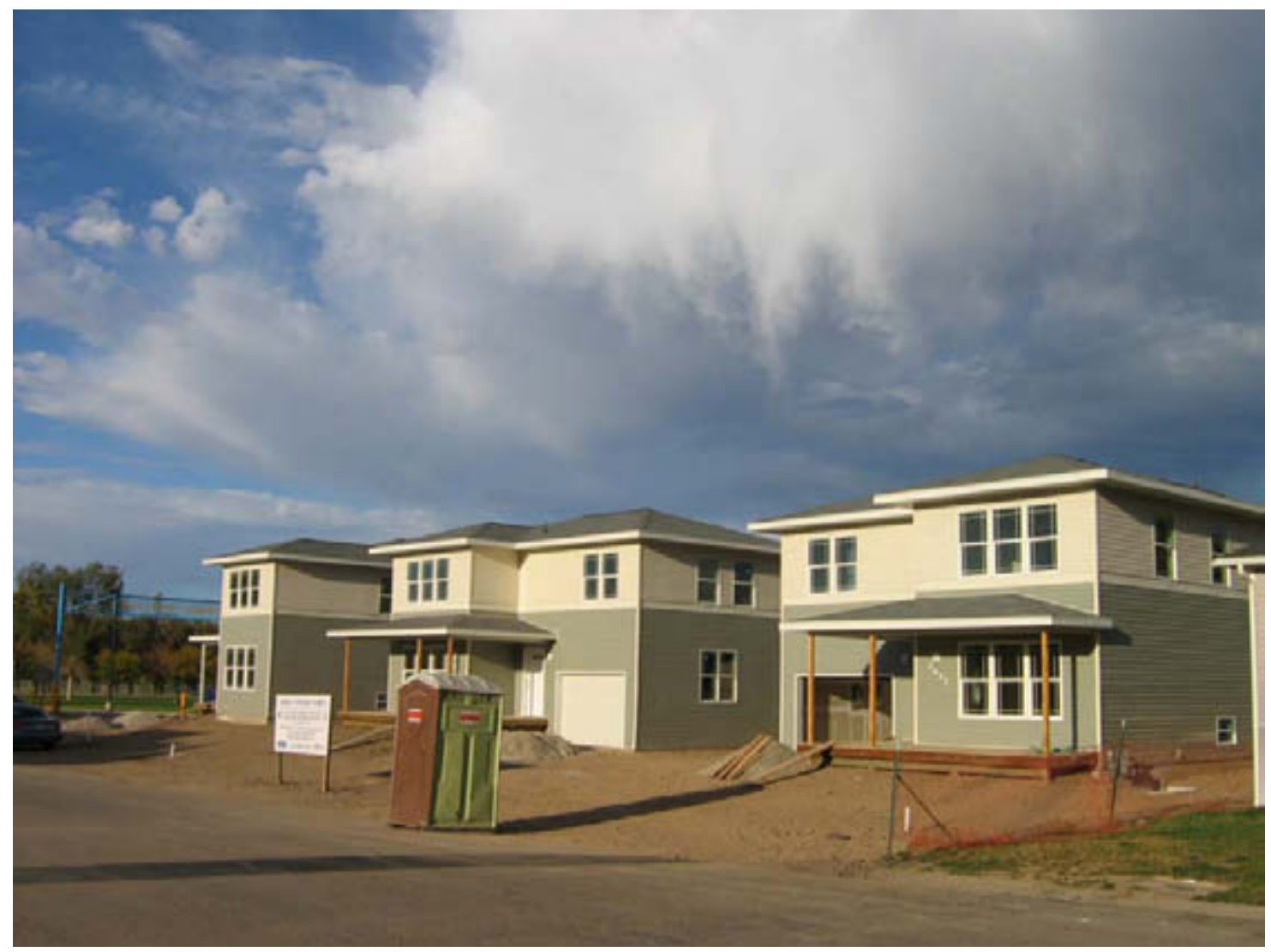

Figure 3. Building America prototype homes at Magna, Utah

Units \#2 and \#3 (rightmost and center in Figure 3) have four bedrooms and 2.5 baths. The floor plans of Units 2 and 3 are mirror images of each other. Unit \#1 has the OASys two-stage indirect/direct evaporative cooler plus a "dynamic ceiling." This system exhausts cool air though the attic insulation via ducts in the ceiling drywall; exhaust air then flows into a small plenum between the ceiling drywall and a wire mesh attached to the bottom of the trusses. Ceiling drywall is installed over standoffs that separate the attic insulation from the drywall. The OASys unit at the Magna location is shown in Figure 4.

Unit \#2 uses the Freus outdoor evaporative condenser coil in conjunction with an oversized Carrier indoor evaporator coil (outdoor unit pictured in Figure 5).

Unit \#3 uses a conventional split-system air conditioner with a SEER rating of 12.

The Borrego Springs project consists of four houses, two of which use OASys systems and conventional split-system air-conditioner backup cooling systems, one that uses a conventional split-system air conditioner with a SEER rating of 21, and one that uses a Freus system. The house using the Freus system has an additional innovative feature. When the unit is not operating, such as during the evenings and swing seasons, the Freus evaporative condenser can operate like a cooling tower, and water can be recirculated between it and the concrete floor slab. One of the homes with the OASys system utilizes a similar floor-cooling feature for its compressor-cooling backup system, the traditional air-source outdoor condensing unit is used to chill water, which is circulated through the floor slab and a fan coil to provide dehumidification. 
The first progress report from the National Renewable Energy Laboratory (NREL; Eastment et al. 2005) provided an overview of benefits and barriers, detailed descriptions of the OASys and Freus units, and instrumentation plans. This report updates monitoring plans, provides the latest results of measurements of a Freus and an OASys system taken at the Magna homes, and gives the results of annual simulations of the two different cooling systems in various climates.

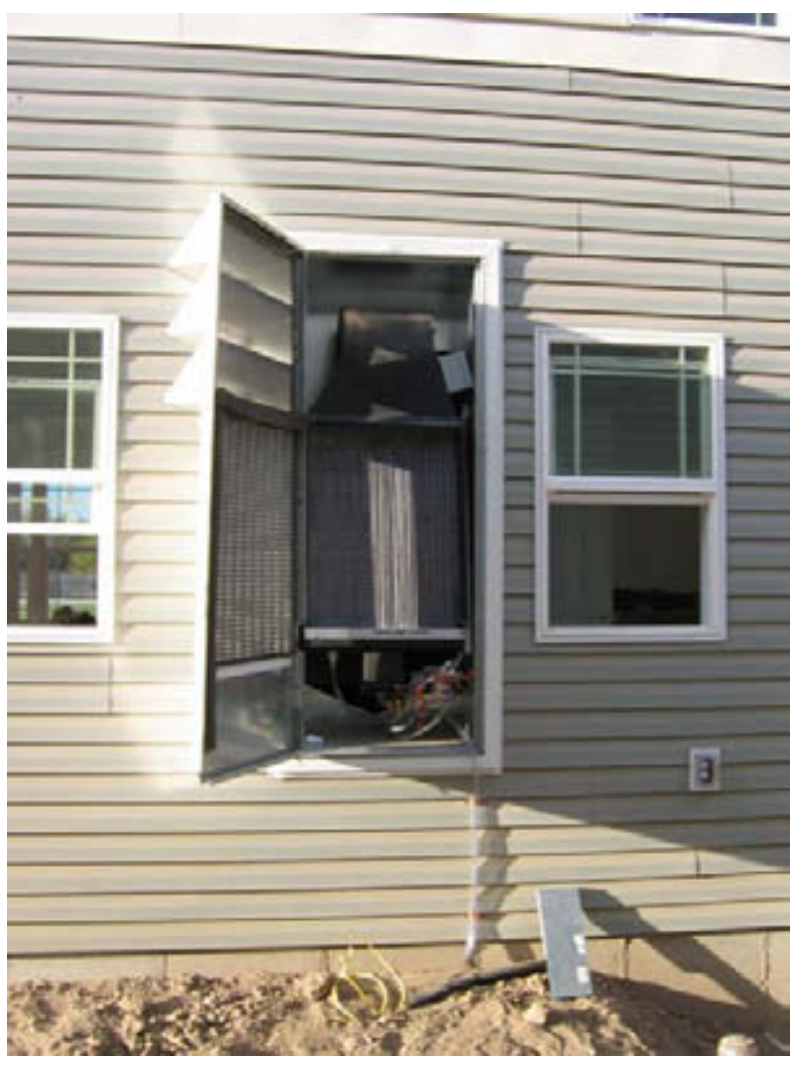

Figure 4. OASys unit installed at Magna Unit 1 


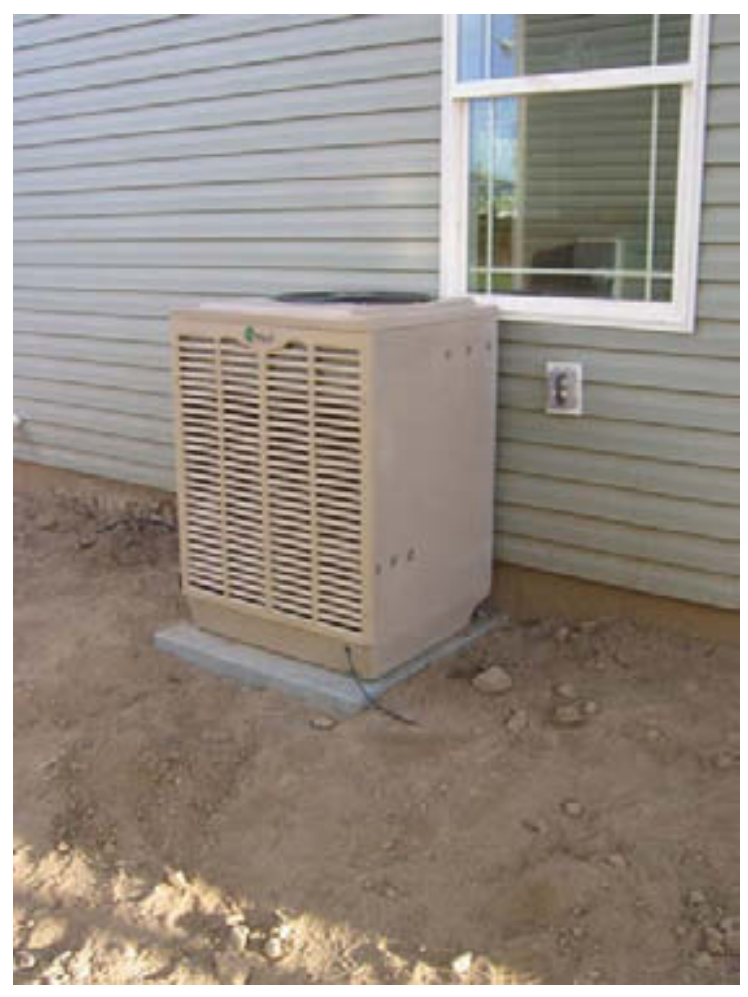

Figure 5. Freus condensing unit installed at Magna Unit 2

\subsection{Simulation Results}

Annual hour-by-hour DOE-2 simulations were made for two houses: the prototype house and a "standard" house. Both house models are based on the same floor plan (shown in Figure 6): a single-story, three-bedroom house with $1,936 \mathrm{ft}^{2}$ of conditioned space. The prototype SIP walls with R-23 nominal insulation, $\mathrm{R}-42$ ceiling insulation, low-e windows $(\mathrm{SC}=0.25, \mathrm{U}=0.36$ ), ENERGY STAR appliances, compact fluorescent lighting, whole house infiltration was modeled to be roughly $0.35 \mathrm{ACH}$. The prototype included 6-ft overhangs, side fins, and extensive landscaping. The prototype has a nominal 2-ton cooling capacity requirement.

The "Standard" house has insulation and equipment levels more common to standard new construction: $2 \times 4$ wall construction with nominal R-13 insulation and exterior sheathing (R1.75), R-30 ceiling insulation, the same low-e glass, and only typical shading because of the soffit overhangs (no side fins, extended roof deck, or landscape shading). The standard house has standard lighting and appliance levels and a nominal 3-ton cooling requirement. 


\section{Borrego Springs - Typical Floor Plan}

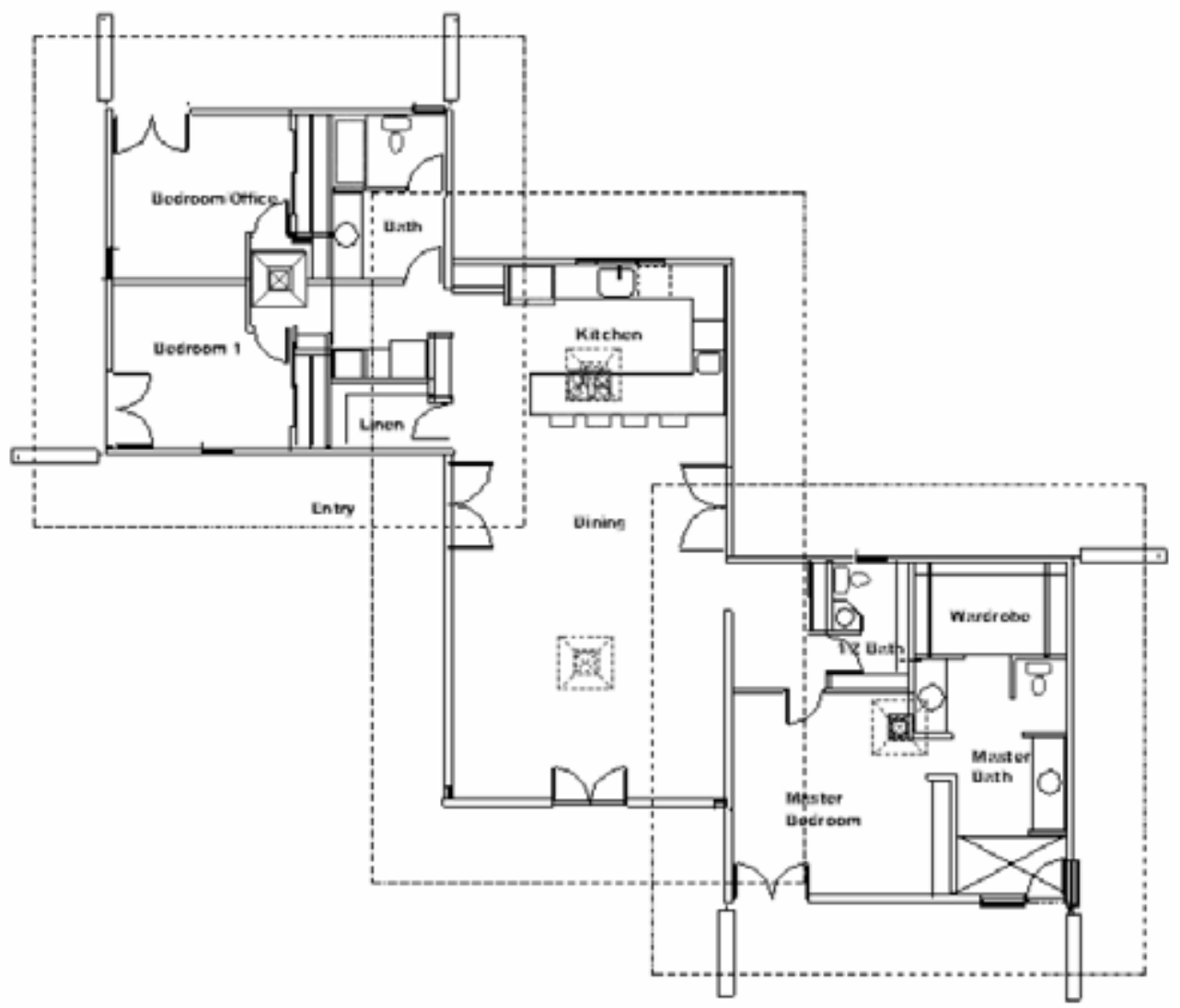

Figure 6. Common floor plan for Borrego Springs homes

The prototype house reduces the cooling load by about $50 \%$ compared to the standard new construction. Runs simulating both houses were completed for alternative cooling systems operating in nine climates: Borrego Springs, Phoenix, Salt Lake City, Sacramento, Denver, Albuquerque, Las Vegas, Los Angeles, and San Diego.

In each climate the cooling systems for each house were changed to the following for the purpose of comparison:

- Conventional SEER 10 direct expansion (DX) split-system air conditioner

- Conventional SEER 13

- Conventional SEER 15

- Freus (modeled as a SEER 13 plus 100\% effectiveness evaporative pre-cooling of condenser)

- Combination of SEER 10 conventional plus OASys

- Combination of SEER 13 conventional plus OASys

- OASys alone with manual control 
- OASys alone with optimal control

- A stand-alone direct evaporative cooler.

All of the DX systems (direct expansion, split-system air conditioners for which Seasonal Energy Efficiency Ratio [SEER] values are given above) were assumed to be 3 tons $(36,000 \mathrm{Btu} / \mathrm{h})$ in the standard house and 2 tons $(24,000 \mathrm{Btu} / \mathrm{h})$ in the prototype house. The specifications for the SEER 10, 13, and 15 units were based on the "median performing units" in a Southern California Edison study. The two-stage OASys unit was assumed to have a heat exchange effectiveness of $45 \%$ (based on NREL lab testing of an OASys unit) for the indirect stage and a wet-bulb effectiveness of $85 \%$ for the evaporative stage, independent of supply flow rate, based on manufacturer's data. (Manufacturer's data indicates that effectiveness values vary only slightly between low and high fan speeds.) The model used fan power values determined by measurements at NREL. For the stand-alone OASys systems, manual control was based on the assumption that the homeowner would switch speeds as needed. Optimal control saved fan power by minimizing full-speed operation.

We were not able to obtain a performance map for a Freus unit. Also, we do not currently have a way to model the evaporative condenser of the Freus unit in DOE-2. This was, therefore, modeled as a stand-alone, $100 \%$ effective, evaporative pre-cooler upstream of a regular aircooled condenser. Because of the thermal resistance between the refrigerant coil and the air stream, this tends to underestimate heat rejection compared to a wetted coil. Thus, predicted energy savings for the Freus unit should be conservative. Based on manufacturer's data, we assumed an electric power use of $0.0017 \mathrm{~W}$ per Btu of ARI capacity (American Refrigeration Institute).

The DOE-2 models that combine conventional DX cooling backup and OASys evaporative systems assumed that the evaporative system would operate alone unless the indoor temperature setting could not be met, at which time the DX unit would also operate. No upper limit was set on indoor humidity.

A simple, stand-alone, direct-evaporative cooler was modeled to allow comparison with the advanced evaporative cooling units. Its flow rate was assumed to be 1,950 CFM.

An active data-collection program for the OASys and Freus units is being undertaken in Borrego Springs, California, so we will first present the simulated performance data from this site. Table 2 shows the cooling energy required for each type of system for the prototype house. This is divided into the energy required by the outdoor unit (some combination of compressor, condenser fan, and water pump, depending on the system type). Table 2 also shows the number of hours any zone was under-cooled and the number of hours living-room indoor humidity and dry-bulb temperatures exceeded different values. Finally, the percent reductions in electric energy consumption compared to SEER 10 and SEER 13 units were included.

A number of conclusions can be drawn from this analysis for a house in Borrego Springs:

- All of the advanced concepts and the simple direct-evaporative cooler show significant electric energy savings compared to the reference air conditioners.

- The OASys systems and the direct-evaporative cooler save considerably more energy than the Freus. The OASys provides a lower supply-air temperature and so can operate at a lower 
CFM and for a shorter period of time than a direct-evaporative cooler. However, it also has fan power associated with an exhaust air stream.

- The stand-alone OASys saves more energy than the OASys units that operate in parallel with air conditioners.

- An optimally controlled OASys unit has about $23 \%$ less energy consumption than the manually controlled one.

- The stand-alone OASys and, especially, the simple direct-evaporative cooler result in more than 400 hours of operation when the indoor relative humidity $(\mathrm{RH})$ is above $70 \%$ for the Borrego Springs climate. In addition, the direct-evaporative cooler results in more than 400 hours when the indoor dry-bulb temperature exceeds $80^{\circ} \mathrm{F}$. 
Table 2. DOE-2 Simulation Results for the Prototype House in

Borrego Springs, California, using Different Cooling Systems

\begin{tabular}{|c|c|c|c|c|c|c|c|c|c|c|c|c|}
\hline \multirow[b]{3}{*}{ Description } & \multirow{2}{*}{\multicolumn{3}{|c|}{ Cooling Energy (kWh/yr) }} & \multirow{3}{*}{$\begin{array}{c}\text { Annual } \\
\text { COP }\end{array}$} & \multirow{3}{*}{$\begin{array}{c}\text { Annual } \\
\text { Effective } \\
\text { SEER }\end{array}$} & \multicolumn{5}{|c|}{ Number of Hours } & \multirow{2}{*}{\multicolumn{2}{|c|}{$\%$ Decrease Base = }} \\
\hline & & & & & & \multirow{2}{*}{$\begin{array}{c}\text { Any } \\
\text { Zone } \\
\text { Under } \\
\text { cooled }\end{array}$} & \multicolumn{2}{|c|}{ Humidity } & \multicolumn{2}{|c|}{ Living Room } & & \\
\hline & Unit & Supply Fan & Total & & & & $>60 \%$ & $>70 \%$ & $>80 \mathrm{~F}$ & $>85 \mathrm{~F}$ & SEER10 & SEER13 \\
\hline SEER $10 \mathrm{DX}$ & 3911 & 472 & 4383 & 2.2 & 7.4 & 0 & 14 & 0 & 0 & 0 & & \\
\hline SEER 13 DX & 2935 & 313 & 3248 & 2.9 & 10.0 & 0 & 14 & 0 & 0 & 0 & $26 \%$ & \\
\hline SEER 15 DX & 2845 & 288 & 3133 & 3.0 & 10.3 & 3 & 15 & 0 & 0 & 0 & $29 \%$ & $4 \%$ \\
\hline $\begin{array}{l}\text { FREUS }^{1} \\
\text { (SEER } 13+\text { ECC) }\end{array}$ & 2137 & 422 & 2559 & 3.6 & 12.4 & 0 & 14 & 0 & 0 & 0 & $42 \%$ & $21 \%$ \\
\hline $\begin{array}{l}\text { SEER } 10+ \\
\text { OASYS }^{2}\end{array}$ & 2778 & 825 & 3603 & 2.6 & 8.9 & 113 & 302 & 88 & 0 & 0 & $18 \%$ & $-11 \%$ \\
\hline $\begin{array}{l}\text { SEER } 13+ \\
\text { OASYS }^{2}\end{array}$ & 1966 & 555 & 2521 & 3.8 & 12.8 & 53 & 507 & 112 & 0 & 0 & $42 \%$ & $22 \%$ \\
\hline $\begin{array}{l}\text { OASYS - Manual } \\
\text { control }^{3}\end{array}$ & 81 & 805 & 886 & 10.4 & 35.5 & 568 & 950 & 417 & 103 & 0 & $80 \%$ & $73 \%$ \\
\hline $\begin{array}{l}\text { OASYS - Optimal } \\
\text { control }^{3}\end{array}$ & 61 & 606 & 667 & 13.8 & 47.2 & 568 & 950 & 417 & 103 & 0 & $85 \%$ & $79 \%$ \\
\hline $\begin{array}{l}\text { Stand-alone Direct } \\
\text { Evaporator }\end{array}$ & 41 & 515 & 556 & 16.0 & 54.6 & 954 & 1213 & 474 & 436 & 3 & $87 \%$ & $83 \%$ \\
\hline
\end{tabular}

\footnotetext{
${ }^{1}$ The FREUS units add an evaporative pre-cooler to the condenser with an effectiveness of $100 \%$ and an electric use of 0.0017 Watts per BTU of ARI capacity.

${ }^{2}$ The DOE2 model of the combined DX and Evaporative system switches between DX cooling and evaporative cooling. There is no maximum indoor humidity control.

${ }^{3}$ Manual control switches between high speed and low speed based on expected peak temperatures, optimal control minimizes full-speed operation. These are stand-alone OASYS systems (no DX cooling).
} 
Table 3. DOE-2 Simulation Results for a Prototype House in Albuquerque, New Mexico, using Different Cooling systems ${ }^{4}$

\begin{tabular}{|c|c|c|c|c|c|c|c|c|c|c|c|c|}
\hline \multirow[b]{3}{*}{ Description } & \multirow{2}{*}{\multicolumn{4}{|c|}{ Cooling Energy (kWh/yr) }} & \multirow{3}{*}{$\begin{array}{c}\text { Annual } \\
\text { Effective } \\
\text { SEER }\end{array}$} & \multicolumn{5}{|c|}{ Number of Hours } & \multirow{2}{*}{\multicolumn{2}{|c|}{$\begin{array}{c}\% \text { Decrease Base } \\
=\end{array}$}} \\
\hline & & & & & & \multirow{2}{*}{$\begin{array}{c}\text { Any Zone } \\
\text { Under } \\
\text { cooled }\end{array}$} & \multicolumn{2}{|c|}{ Humidity } & \multicolumn{2}{|c|}{ Living Room } & & \\
\hline & $\begin{array}{l}\text { Outdoor } \\
\text { Unit }\end{array}$ & $\begin{array}{l}\text { Supply } \\
\text { Fan }\end{array}$ & Total & $\begin{array}{l}\text { Annual } \\
\text { COP }\end{array}$ & & & $>60 \%$ & $>70 \%$ & $>80 \mathrm{~F}$ & $>85 \mathrm{~F}$ & SEER10 & SEER13 \\
\hline SEER $10 \mathrm{DX}$ & 483 & 59 & 542 & 2.2 & 7.6 & 0 & 78 & 0 & 0 & 0 & & \\
\hline SEER 13 DX & 339 & 38 & 377 & 3.2 & 11.0 & 0 & 79 & 0 & 0 & 0 & $30 \%$ & \\
\hline SEER 15 DX & 335 & 36 & 371 & 3.3 & 11.2 & 0 & 78 & 0 & 0 & 0 & $32 \%$ & $2 \%$ \\
\hline $\begin{array}{l}\text { FREUS }^{1} \text { (SEER } 13+ \\
\text { ECC) }\end{array}$ & 275 & 53 & 328 & 3.6 & 12.4 & 0 & 79 & 0 & 0 & 0 & $40 \%$ & $13 \%$ \\
\hline SEER $10+$ OASYS $^{2}$ & 17 & 112 & 129 & 9.4 & 32.1 & 0 & 147 & 2 & 0 & 0 & $76 \%$ & $66 \%$ \\
\hline SEER $13+$ OASYS $^{2}$ & 12 & 77 & 89 & 13.7 & 46.6 & 0 & 149 & 2 & 0 & 0 & $84 \%$ & $76 \%$ \\
\hline OASYS - Manual control ${ }^{3}$ & 6 & 60 & 66 & 17.7 & 60.3 & 0 & 148 & 7 & 0 & 0 & $88 \%$ & $83 \%$ \\
\hline OASYS - Optimal control ${ }^{3}$ & 4 & 37 & 41 & 28.6 & 97.6 & 0 & 148 & 7 & 0 & 0 & $92 \%$ & $89 \%$ \\
\hline $\begin{array}{l}\text { Stand-alone Direct } \\
\text { Evaporator }\end{array}$ & 4 & 55 & 59 & 20.1 & 68.6 & 0 & 233 & 12 & 0 & 0 & $89 \%$ & $84 \%$ \\
\hline
\end{tabular}

\footnotetext{
${ }^{4}$ Notes from Table 1 apply
} 
Results for Phoenix are similar to those for Borrego Springs. Results for a less-extreme dry climate with a milder rainy season (Albuquerque) are shown in Table 3.

Compared to Borrego Springs, the cooling season is much shorter; therefore, total annual cooling energy use is much less. But similar trends apply. The direct-evaporative cooler and the OASys unit require much less electricity than the conventional air conditioners. Because Albuquerque does not get as much rain as Borrego Springs, the evaporative cooling systems are not penalized with many hours outside the comfort zone. Both the OASys and direct evaporative coolers work well for this climate.

As suggested by Tables 2 and 3, it is important not only to consider the cooling energy but also the number of hours the indoor conditions may be outside comfort conditions. It is also worthwhile to consider the distribution of these hours. Figures 7 and 8 show, respectively, the distribution of hours outside comfort conditions for the direct-evaporative cooler and the OASys for the prototype house in Borrego Springs. The blue (dark) bar indicates hours on a given date when the temperature, humidity, or both, were too high. The red (light) indicates the number of hours when only the temperature was too high. The OASys clearly does much better than the evaporative cooler, and it is also clear why the Borrego Springs house relies on a combination of the OASys and a conventional direct-expansion system. An evaporative unit alone cannot provide adequate comfort conditions during the monsoon season.

Figures 9 and 10 show the rainy results for Albuquerque. Here, both the direct-evaporative cooler and the OASys provide sufficiently cool indoor temperatures throughout the cooling season. Both result in some hours when the indoor humidity is high, but the OASys is considerably better than the direct-evaporative cooler because of its indirect stage.

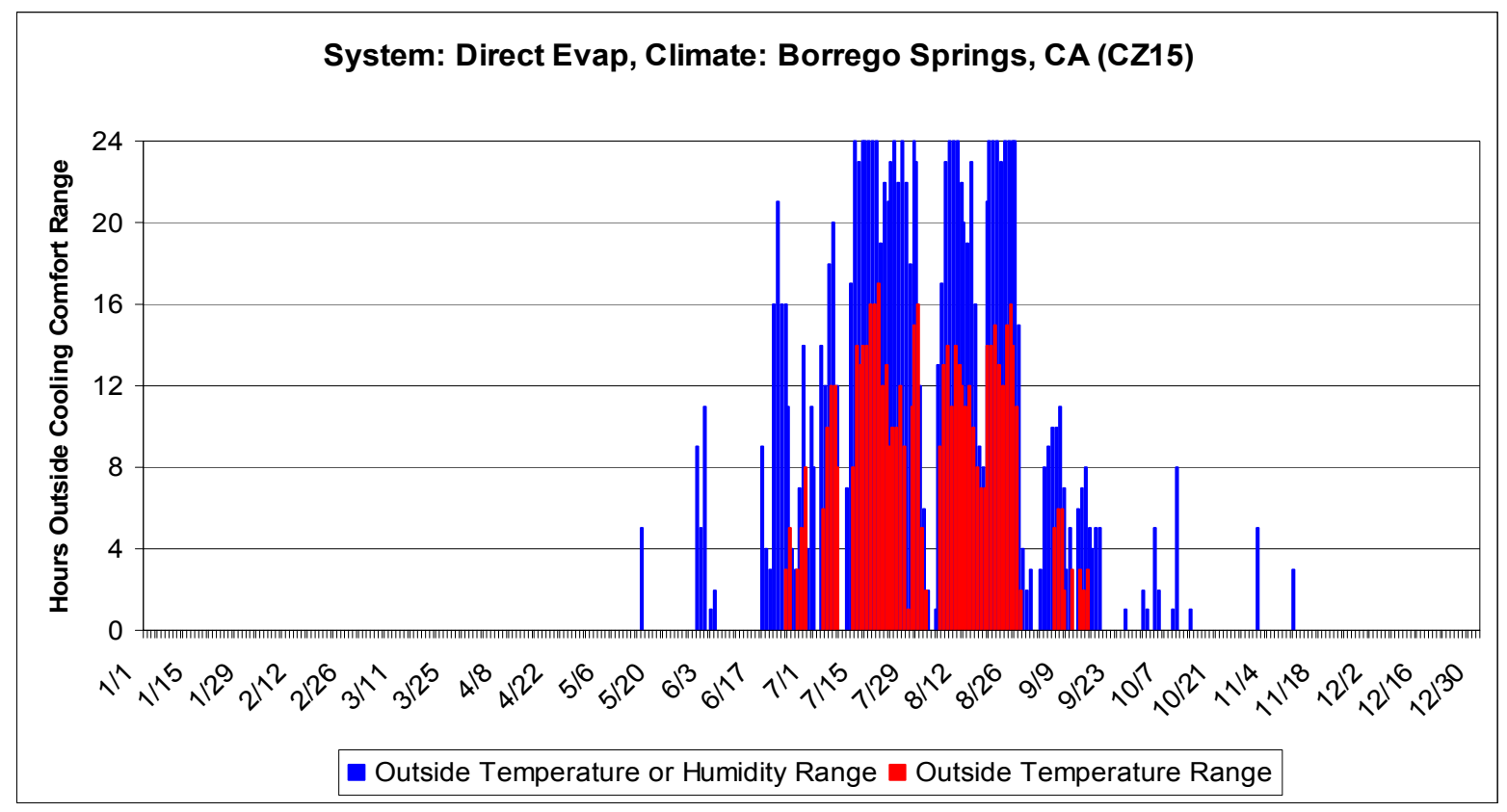

Figure 7. Distribution of hours when indoor temperature or humidity are too high for direct-evaporative cooler in Borrego Springs, California 


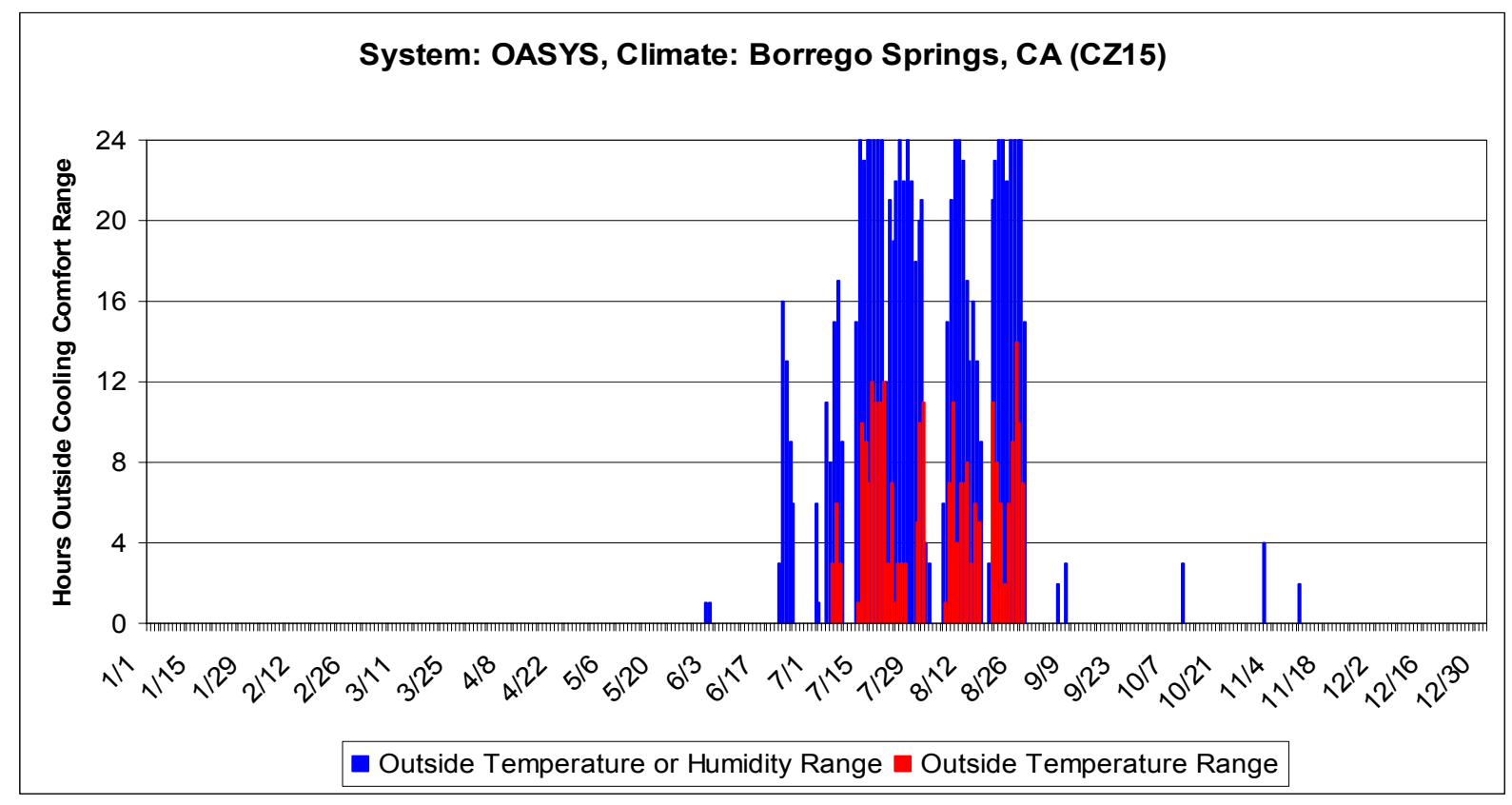

Figure 8. Distribution of hours when indoor temperature or humidity are too high for OASys unit in Borrego Springs, California

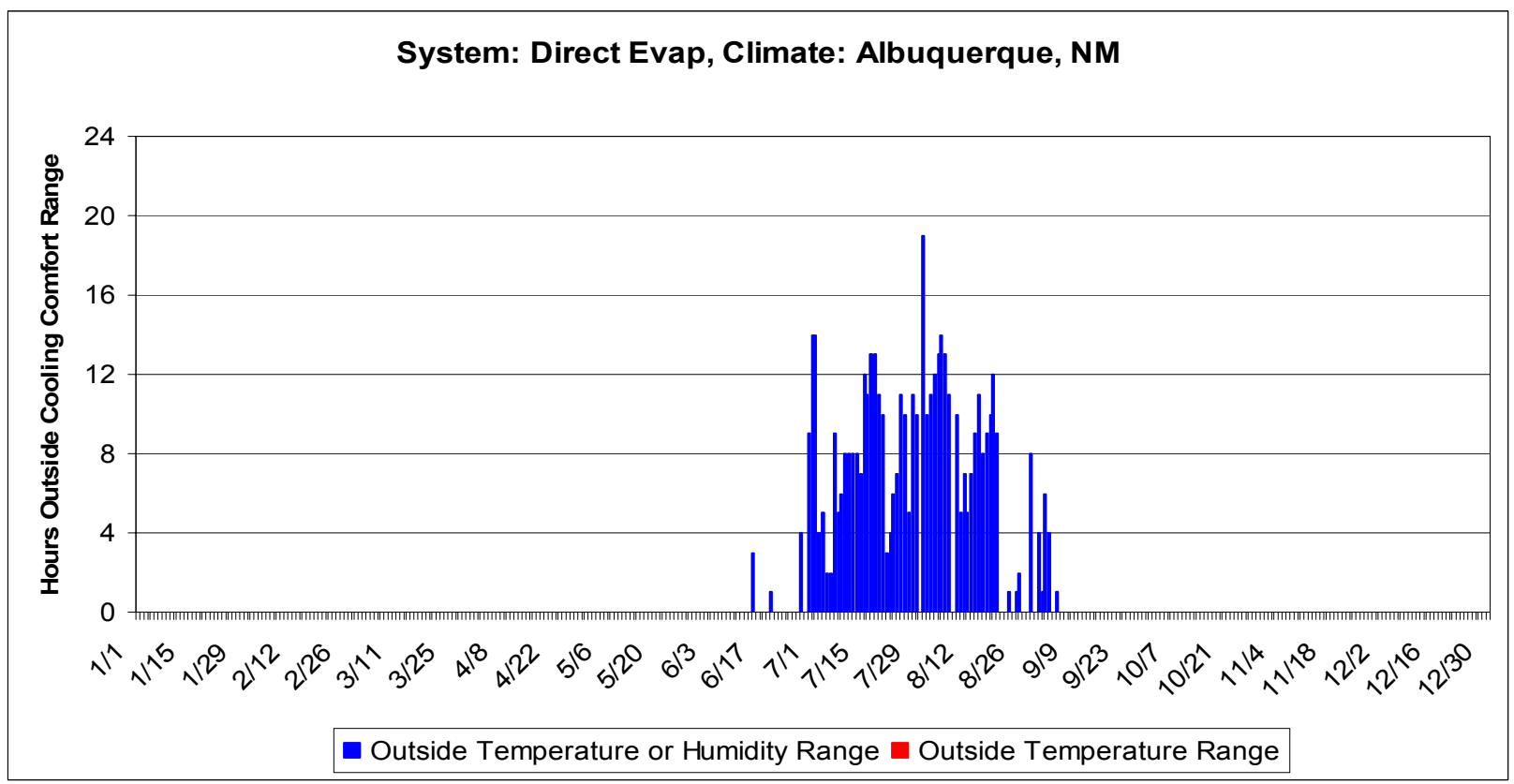

Figure 9. Distribution of hours when indoor temperature or humidity are too high for direct-evaporative cooler in Albuquerque, New Mexico 


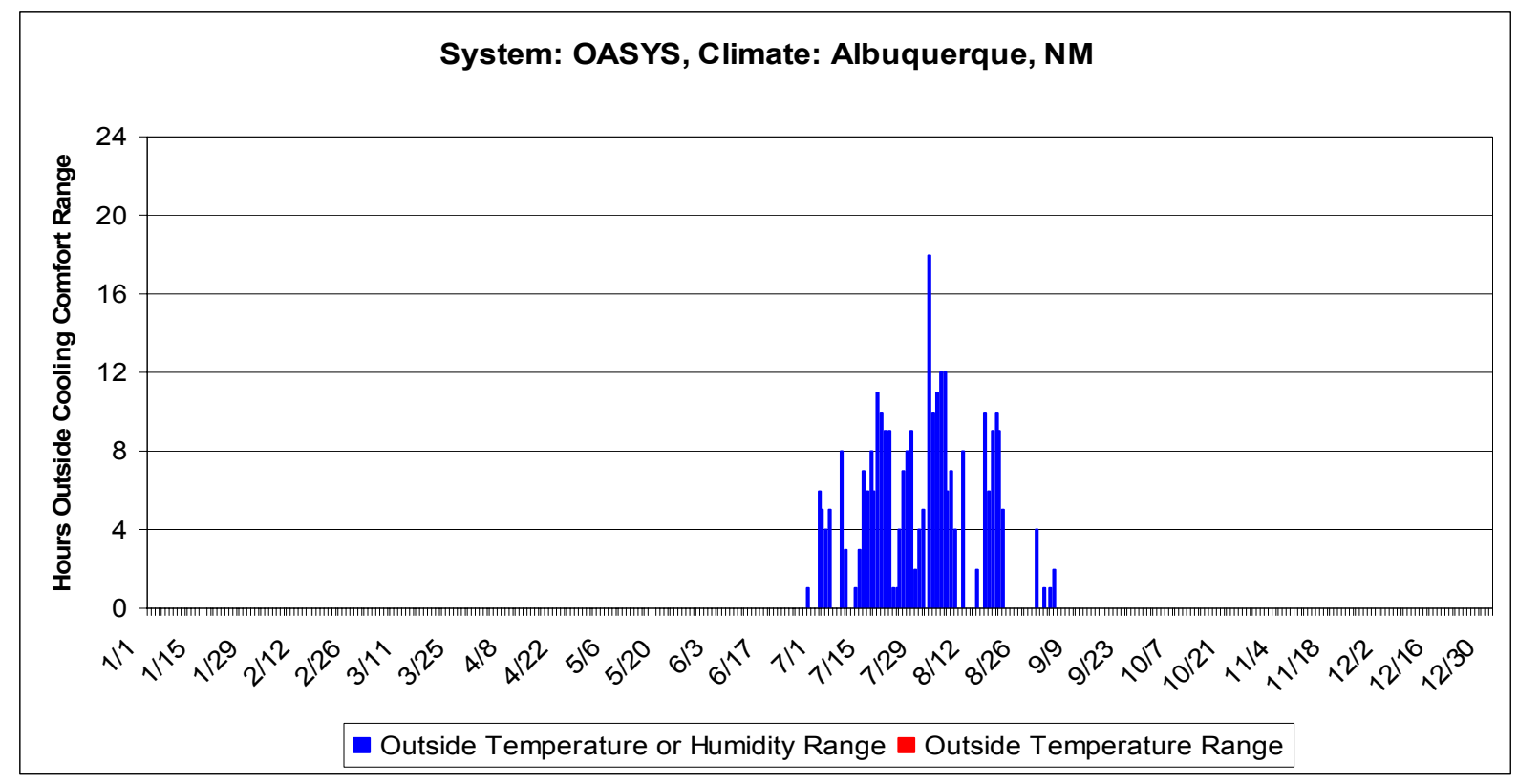

Figure 10. Distribution of hours when indoor temperature or humidity are too high for OASys system in Albuquerque, New Mexico 
Figure 11 shows a comparison of the Freus, OASys, direct-evaporative cooling, and a reference SEER 13 unit in all climates; results are displayed as a fraction of SEER 13 unit energy use. In hot, dry climates like Phoenix, Borrego Springs, and Las Vegas, the OASys unit and a directevaporative cooler can significantly reduce cooling energy use. In cooler dry climates like Albuquerque and Denver, the OASys and direct-evaporative cooler cause a smaller reduction in the absolute amount of cooling energy because the annual cooling loads are less. However, they make very sizeable percent reductions in the cooling energy use.

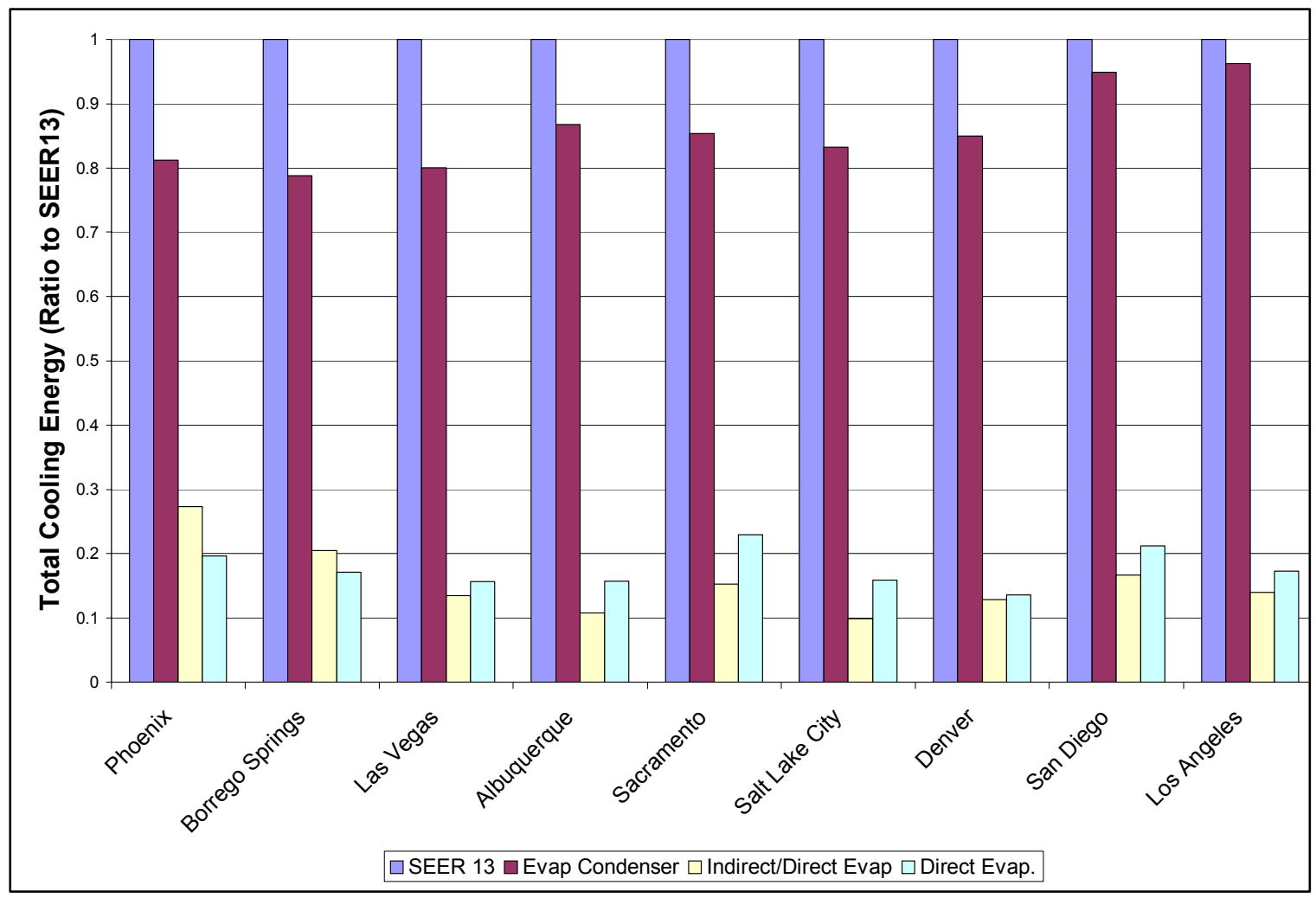

Figure 11. Comparison of four cooling systems in various locations 


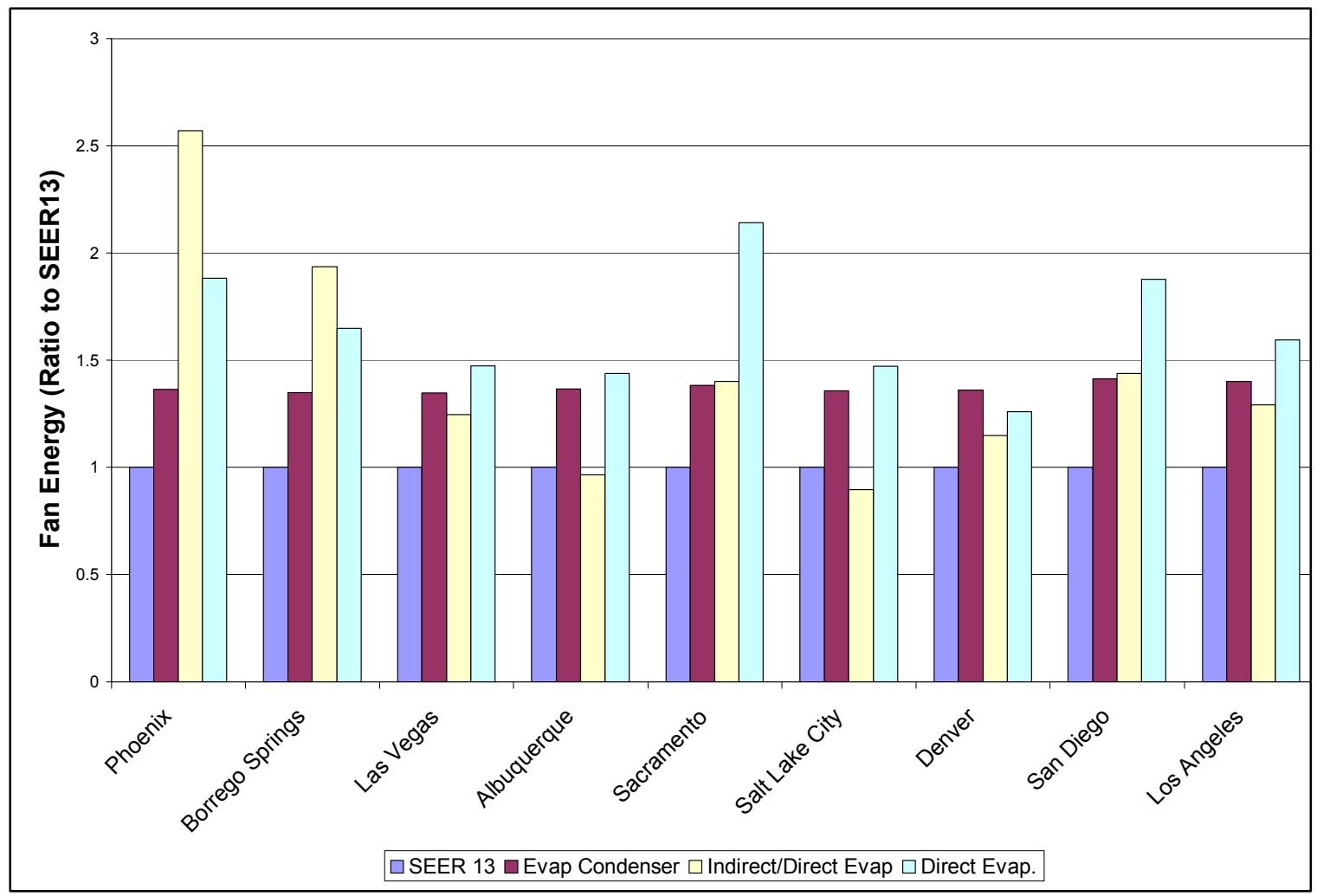

Figure 12. Comparison of fan energy use for cooling systems in various locations

In some climates the indirect/direct evaporative cooler uses less total energy on an annual basis, this is primarily a result of the fan energy use of the indirect/direct evaporative cooler. Figure 12 shows a comparison of fan energy, results are displayed as a fraction of SEER 13 fan energy use.

In hot climates, the OASys indirect/direct evaporative cooler spends more time running at maximum capacity and maintains better interior comfort than the direct evaporative cooler, but at the expense of added energy use. The indirect/direct evaporative cooler is able to deliver cooler air to the space, whereas the direct evaporative cooler is oftentimes unable to maintain comfortable conditions within the living space. The energy consumption of the OASys fan at maximum capacity is greater than the energy use of the direct evaporative cooler at maximum capacity. Therefore, it is not surprising that in hot climates, where both units spend more time at maximum capacity, the OASys will use more fan energy and total energy than the direct evaporative cooler. In smaller cooling load climates, the OASys indirect/direct evaporative cooler uses less fan energy because it spends more time in low-speed mode and can meet the cooling load by utilizing a more efficient part of the fan curve, compared to a single-speed fan used by the direct evaporative cooler.

\subsection{Monitoring Status}

Steven Winter Associates/Consortium for Advanced Residential Buildings (SWA/CARB), in cooperation with NREL, is collecting data on the OASys and Freus units at a Building America project site in Magna, Utah. In the past 6 months, NREL staff has worked closely with engineers 
from the Davis Energy Group (DEG) and Building Industry Research Alliance (BIRA) to revise the instrumentation and monitoring plans for the Borrego Springs houses, a second Building America project in a very hot-dry climate. Data collected at these sites will be used to understand field performance and provide better inputs to our models. The monitoring systems installed at each of the homes in Borrego Springs were designed to answer specific performance questions related to the cooling systems in addition to monitoring the performance of the home as a whole. The focus of the discussion here will be limited to the evaluation and comparison of the various cooling systems present at the Borrego Springs homes. The following list of questions were developed and used to direct the specification the instrumentation with the intent of providing answers to the cooling system performance questions:

- Do the cooling systems perform near manufacturers' performance specifications?

- What are the cooling systems' measured EER and capacity as functions of indoor and outdoor conditions?

- What is the water consumption of the cooling system?

- What is the measured wet-bulb effectiveness of the evaporative systems?

- Do the homes maintain comfortable indoor conditions?

- What are the actual outdoor conditions at the site?

Some of the questions that are asked relate to the modeling effort in order to improve existing models or create new component models or validate simulation predictions of performance:

- How do simulation results compare to measured cooling system performance?

- To what extent are evaporative-cooling systems capable of meeting cooling and comfort criteria at various times of the year and will conventional AC backup be required?

- In terms of annual cooling energy use how do the cooling systems or combination of systems compare given the same envelope, internal loads, and outdoor conditions while maintaining acceptable comfort conditions?

In order to understand outdoor conditions and interpret performance data from these sites, it is necessary to collect weather data. Section 3.1 describes a weather station specification for the Borrego Springs site. Sections 3.2 and 3.3 describe the monitoring systems installed for the evaluation of the OASys and Freus cooling systems, respectively.

\subsection{Borrego Springs Weather Station Specifications}

To understand the performance of the homes, cooling systems, and validate simulation models it is important to understand the actual weather conditions at the site of interest. Horizontal insolation; outdoor temperature; and $\mathrm{RH}$, wind speed, and wind direction are continuously monitored at the East Star home site at Borrego Springs. The latest specifications for the Borrego Springs weather station are given in Table 4. 
Table 4. Weather Station Sensors

\begin{tabular}{|c|c|c|c|c|c|c|c|}
\hline $\begin{array}{c}\text { Data } \\
\text { Required }\end{array}$ & Measurement & Sensor Type & Sensor Part \# & Sensor Accuracy & $\begin{array}{l}\text { Installed } \\
\text { Location }\end{array}$ & Quantity & More Info \\
\hline $\begin{array}{l}\text { Horizontal } \\
\text { solar radiation }\end{array}$ & $\begin{array}{l}\text { Continuously } \\
\text { monitored } \\
\text { Irradiance }\end{array}$ & $\begin{array}{l}\text { Photocell-type } \\
\text { pyranometer }\end{array}$ & LI-200SZ & $\begin{array}{l}\text { Absolute Error } \\
\pm 5 \% \text {, Typically } \\
\pm 3 \%\end{array}$ & $\begin{array}{l}\text { Custom } \\
\text { mounted on } \\
\text { highest roof } \\
\text { cupola } \\
\text { (above dome } \\
\text { skylight) }\end{array}$ & 1 & www.licor.com/ \\
\hline Wind speed & $\begin{array}{l}\text { Continuously } \\
\text { monitored AC } \\
\text { voltage }\end{array}$ & $\begin{array}{l}\text { Rotating magnet } \\
\text { on cup-wheel shaft }\end{array}$ & 03100-LXXX & $\pm 0.5 \mathrm{~m} / \mathrm{s}(1.1 \mathrm{mph})$ & $\begin{array}{l}\text { Tripod on } \\
\text { roof }\end{array}$ & 1 & $\frac{\text { www.campbellsci.com/index.cfm }}{\text { Threshold }-0.5 \mathrm{~m} / \mathrm{s}(1.1 \mathrm{mph})}$ \\
\hline Wind direction & $\begin{array}{l}\text { Continuously } \\
\text { monitored DC } \\
\text { voltage }\end{array}$ & Potentiometer & 03100-LXXX & $\pm 5^{\circ}$ & $\begin{array}{l}\text { Tripod on } \\
\text { roof }\end{array}$ & 1 & www.campbellsci.com/index.cfm \\
\hline \multirow{2}{*}{$\begin{array}{l}\text { Outdoor-air } \\
\text { absolute } \\
\text { humidity }\end{array}$} & $\begin{array}{l}\text { Continuously } \\
\text { monitored outdoor- } \\
\text { air dry-bulb } \\
\text { temperature }\end{array}$ & $\begin{array}{l}\text { Resistance } \\
\text { temperature device } \\
\text { (thermistor) }\end{array}$ & \multirow{2}{*}{ Vaisala HMP-50 } & $\begin{array}{l} \pm 1.1^{\circ} \mathrm{F} @ 68^{\circ} \mathrm{F} \\
\text { see online specs } \\
\text { for full accuracy } \\
\text { specs }\end{array}$ & \multirow{2}{*}{$\begin{array}{l}\text { Pole } \\
\text { mounted in } \\
\text { back yard, } \\
\text { shielded, } \\
\text { naturally } \\
\text { aspirated }\end{array}$} & \multirow{2}{*}{1} & \multirow{2}{*}{ www.vaisala.com } \\
\hline & $\begin{array}{l}\text { Continuously } \\
\text { monitored outdoor } \\
\text { air RH }\end{array}$ & $\begin{array}{l}\text { Variable- } \\
\text { capacitance-type } \\
\text { RH sensor }\end{array}$ & & $\begin{array}{l}90-98 \% \pm 5 \%, \text { see } \\
\text { online specs for } \\
\text { full accuracy specs }\end{array}$ & & & \\
\hline $\begin{array}{l}\text { Outdoor-air } \\
\text { dry-bulb } \\
\text { temperature }\end{array}$ & $\begin{array}{l}\text { Continuously } \\
\text { monitored outdoor- } \\
\text { air dry-bulb } \\
\text { temperature }\end{array}$ & $\begin{array}{l}\text { Twisted, shielded, } \\
\text { stranded, special } \\
\text { limits of error type- } \\
\text { T thermocouple, } \\
\text { Copper/Copper- } \\
\text { Constantan-Nickel }\end{array}$ & $\begin{array}{c}\text { TT-T-24S- } \\
\text { TWSH-SLE-100 } \\
\text { (1000-ft spool) }\end{array}$ & $0.5^{\circ} \mathrm{C}$ or $0.4 \%$ & $\begin{array}{l}\text { Pole } \\
\text { mounted in } \\
\text { back yard, } \\
\text { shielded, } \\
\text { forced } \\
\text { aspiration }\end{array}$ & 2 & www.omega.com \\
\hline
\end{tabular}


The approach for measuring most of the variables shown in Table 4 is fairly straightforward because the sensors are connected directly to a Datataker 800 (www.datataker.com/) datalogger, provided by DEG, for long-term data collection. Data is logged in 15-minute intervals and is a combination of 15-minute averages or totalizations depending on the measurement. Sensors were provided and installed by NREL. Establishing outdoor dry bulb temperature is accomplished with two type-T thermocouples installed in a custom-built forced-aspiration radiation shield. The absolute humidity of outdoor air is established by using a Vaisala HMP-50 temperature and relative-humidity sensor installed in a naturally aspirated plate-style radiation shield.

Temperature and relative-humidity data from this sensor are used to determine the absolute humidity of air, which is logged as part of the datalogger program.

\subsection{Monitoring of the OASys Unit}

The OASys unit takes outdoor air and cools it via a two-stage indirect/direct evaporative cooling process. Several Building America teams are using this system in prototype homes as part of their whole-house research program. NREL, in cooperation with the SWA/CARB is currently monitoring an OASys unit at a Building America home in Magna, Utah (Unit \#1) and will be monitoring a second OASys unit at one of the four Borrego Springs, California, homes in cooperation with BIRA and DEG, pending the completion of construction for these homes. At each of these two houses, NREL is working with the Building America team and partners to monitor outdoor and indoor temperature and humidity conditions, as well as the flow rate and temperature of the supply air. We will also monitor the amount of make-up water provided to and energy consumed by the OASys unit.

To answer the questions regarding the cooling system performance and validate cooling system models, a long-term data-collection system was installed at the Wagon home in Borrego Springs. Details of the instrumentation that was selected to collect data on the OASys operation and performance characteristics are given in Table 5 . 
Table 5. Instrumentation for OASys Unit

\begin{tabular}{|c|c|c|c|c|c|c|c|}
\hline Data Required & Measurement & Sensor Type & Sensor Part \# & Sensor Accuracy & Installed Location & Quantity & More Info \\
\hline \multirow{2}{*}{$\begin{array}{l}\text { Evaporative } \\
\text { cooler fan } \\
\text { energy } \\
\text { consumption }\end{array}$} & \multirow{2}{*}{$\begin{array}{l}\text { Continuously } \\
\text { monitored Watt- } \\
\text { hour Totalization } \\
\text { meter }\end{array}$} & $\begin{array}{l}\text { True RMS AC } \\
\text { watt-hour } \\
\text { transducer with } \\
\text { pulse output }\end{array}$ & WNA-1P-240-P & $\begin{array}{l}0.45 \% \text { of reading }+ \\
0.05 \% \text { of full scale } \\
\text { through } 25 \text { th harmonic }\end{array}$ & $\begin{array}{l}\text { Inside OASys fan } \\
\text { cabinet }\end{array}$ & 1 & www.ccontrolsys.com \\
\hline & & $\begin{array}{l}\text { Split-core CT } \\
(15 \mathrm{amp})\end{array}$ & CTS-0750-015 & $\begin{array}{l}\text { Accuracy } \pm 1 \% \text { from } 10 \% \\
\text { to } 130 \% \text { of rated current }\end{array}$ & $\begin{array}{l}\text { Installed on A- and } \\
\text { B-phase hot leads for } \\
\text { fan within OASys unit } \\
\text { cabinet }\end{array}$ & 2 & www.ccontrolsys.com \\
\hline \multirow{2}{*}{$\begin{array}{l}\text { Evaporative } \\
\text { system pump } \\
\text { energy } \\
\text { consumption }\end{array}$} & \multirow{2}{*}{$\begin{array}{l}\text { Continuously } \\
\text { monitored Watt- } \\
\text { hour Totalization } \\
\text { meter }\end{array}$} & $\begin{array}{l}\text { True RMS AC } \\
\text { watt-hour } \\
\text { transducer with } \\
\text { pulse output }\end{array}$ & WNA-1P-240-P & $\begin{array}{l}0.45 \% \text { of reading }+ \\
0.05 \% \text { of full scale } \\
\text { through } 25 \text { th harmonic }\end{array}$ & $\begin{array}{l}\text { Inside OASys fan } \\
\text { cabinet }\end{array}$ & 1 & www.ccontrolsys.com \\
\hline & & $\begin{array}{l}\text { Split-core CT } \\
(15 \mathrm{amp})\end{array}$ & CTS-0750-015 & $\begin{array}{l}\text { Accuracy } \pm 1 \% \text { from } 10 \% \\
\text { to } 130 \% \text { of rated current }\end{array}$ & $\begin{array}{l}\text { Installed on A- and B- } \\
\text { phase hot leads for } \\
\text { pump within OASys unit } \\
\text { cabinet }\end{array}$ & 2 & www.ccontrolsys.com \\
\hline \multirow{2}{*}{$\begin{array}{l}\text { Evaporative } \\
\text { cooler total } \\
\text { energy } \\
\text { consumption }\end{array}$} & \multirow{2}{*}{$\begin{array}{l}\text { Continuously } \\
\text { monitored Watt- } \\
\text { hour Totalization } \\
\text { meter }\end{array}$} & $\begin{array}{l}\text { True RMS AC } \\
\text { watt-hour } \\
\text { transducer with } \\
\text { pulse output }\end{array}$ & WNA-1P-240-P & $\begin{array}{l}0.45 \% \text { of reading }+ \\
0.05 \% \text { of full scale } \\
\text { through } 25 \text { th harmonic }\end{array}$ & $\begin{array}{l}\text { Inside OASys fan } \\
\text { cabinet }\end{array}$ & 1 & www.ccontrolsys.com \\
\hline & & $\begin{array}{l}\text { Split-core CT } \\
(15 \mathrm{amp})\end{array}$ & CTS-0750-015 & $\begin{array}{l}\text { Accuracy } \pm 1 \% \text { from } 10 \% \\
\text { to } 130 \% \text { of rated current }\end{array}$ & $\begin{array}{l}\text { Installed on main A- } \\
\text { and B-phase hot leads } \\
\text { within OASys unit } \\
\text { cabinet }\end{array}$ & 2 & www.ccontrolsys.com \\
\hline
\end{tabular}


Table 5 (continued). Instrumentation for OASys Unit

\begin{tabular}{|c|c|c|c|c|c|c|c|}
\hline Data Required & Measurement & Sensor Type & Sensor Part \# & Sensor Accuracy & $\begin{array}{l}\text { Installed } \\
\text { Location }\end{array}$ & Quantity & More Info \\
\hline $\begin{array}{l}\text { Evaporative } \\
\text { sump-system } \\
\text { water-inlet flow } \\
\text { rate }\end{array}$ & $\begin{array}{l}\text { Continuously } \\
\text { monitored water flow } \\
\text { rate }\end{array}$ & $\begin{array}{l}\text { Paddle-wheel } \\
\text { flowmeter with } \\
\text { pulse output }\end{array}$ & Model 1702 & $\begin{array}{l}2 \% \text { of reading for } \\
0-0.13 \text { GPM, } \\
\pm 1.5 \% \text { of reading } \\
0.13-13 \text { GPM, } \\
1 / 2 \text {-in. MNPT, } \\
1 \text { pulse/gal }\end{array}$ & $\begin{array}{l}\text { At water inlet } \\
\text { for float valve } \\
\text { on OAsys } \\
\text { cabinet }\end{array}$ & 1 & www.istec-corp.com \\
\hline \multirow{2}{*}{$\begin{array}{l}\text { Evaporative } \\
\text { cooler supply air } \\
\text { volumetric flow } \\
\text { rate }\end{array}$} & \multirow{2}{*}{$\begin{array}{l}\text { Continuously } \\
\text { monitored supply duct } \\
\text { pressure differential }\end{array}$} & $\begin{array}{l}\text { Pitot tube } \\
\text { traverse probe }\end{array}$ & $\begin{array}{l}\text { VOLU-probe } \\
\text { one externally } \\
\text { mounted pitot } \\
\text { airflow traverse } \\
\text { probe }\end{array}$ & $2 \%$ of actual flow & $\begin{array}{l}\text { In supply air } \\
\text { plenum }\end{array}$ & 2 & www.airmonitor.com \\
\hline & & $\begin{array}{l}\text { Pressure } \\
\text { transducer }\end{array}$ & $\begin{array}{l}\text { Veltron } 2500 \\
\text { Plus } 0-0.05 \text { in. } \\
\text { wc span }\end{array}$ & $\begin{array}{l}0.25 \% \text { of natural } \\
\text { span, including non- } \\
\text { linearity, hysteresis, } \\
\text { dead band, and } \\
\text { non-repeatability. }\end{array}$ & $\begin{array}{l}\text { Mounted on } \\
\text { side of supply } \\
\text { plenum }\end{array}$ & 1 & www.airmonitor.com \\
\hline $\begin{array}{l}\text { Evaporative } \\
\text { cooler supply air } \\
\text { volumetric flow } \\
\text { rate }\end{array}$ & $\begin{array}{l}\text { Continuously } \\
\text { monitored heat } \\
\text { transfer from hot wire } \\
\text { type airflow station }\end{array}$ & $\begin{array}{l}\text { Hot wire/heat } \\
\text { transfer type } \\
\text { airflow station }\end{array}$ & $\begin{array}{l}\text { NL } 1 \text { × } 2 \text { air } \\
\text { flow-measuring } \\
\text { station }\end{array}$ & $\begin{array}{l} \pm 2 \% \text { of reading }+ \\
1 / 2 \% \text { OF FS }\end{array}$ & $\begin{array}{l}\text { In supply air } \\
\text { plenum }\end{array}$ & 1 & www.flowmeasurement.com/index.html \\
\hline \multirow{2}{*}{$\begin{array}{l}\text { Supply-air } \\
\text { temperature and } \\
\text { RH }\end{array}$} & $\begin{array}{l}\text { Continuously } \\
\text { monitored Supply air } \\
\text { dry-bulb temperature }\end{array}$ & $\begin{array}{l}\text { Resistance } \\
\text { temperature } \\
\text { device } \\
\text { (thermistor) }\end{array}$ & \multirow{2}{*}{$\begin{array}{l}\text { Vaisala } \\
\text { HMD60Y }\end{array}$} & $\begin{array}{l} \pm 0.2^{\circ} \mathrm{F} @ 68^{\circ} \mathrm{F}, \text { see } \\
\text { online specs for full } \\
\text { accuracy specs }\end{array}$ & \multirow{2}{*}{$\begin{array}{l}\text { In supply air } \\
\text { plenum }\end{array}$} & \multirow{2}{*}{1} & \multirow{2}{*}{ www.vaisala.com } \\
\hline & $\begin{array}{l}\text { Continuously } \\
\text { monitored Supply Air } \\
\text { RH }\end{array}$ & $\begin{array}{l}\text { Variable- } \\
\text { capacitance- } \\
\text { type RH sensor }\end{array}$ & & $\begin{array}{l}0-100 \% \mathrm{RH}= \pm 2 \% \\
@ 68^{\circ} \mathrm{F}, \text { see online } \\
\text { specs for full } \\
\text { accuracy specs }\end{array}$ & & & \\
\hline
\end{tabular}


The approach for measuring most of the variables shown in Table 5 is fairly straightforward because the sensors are connected directly to a Datataker 800 (www.datataker.com/) datalogger, provided by DEG, for long-term data collection. Some sensors were provided and installed by NREL. Data is logged in 15-minute intervals and is a combination of 15-minute averages or totalizations, depending on the measurement. Measuring the airflow provided by the OASys unit is proving to be difficult because of its ability to provide ventilation air at a flow rate of approximately $150 \mathrm{CFM}$. The supply plenum where the multiple airflow sensors are located has a square cross section of 18x24 in.; the initial supply plenum layout is shown in Figure 13.

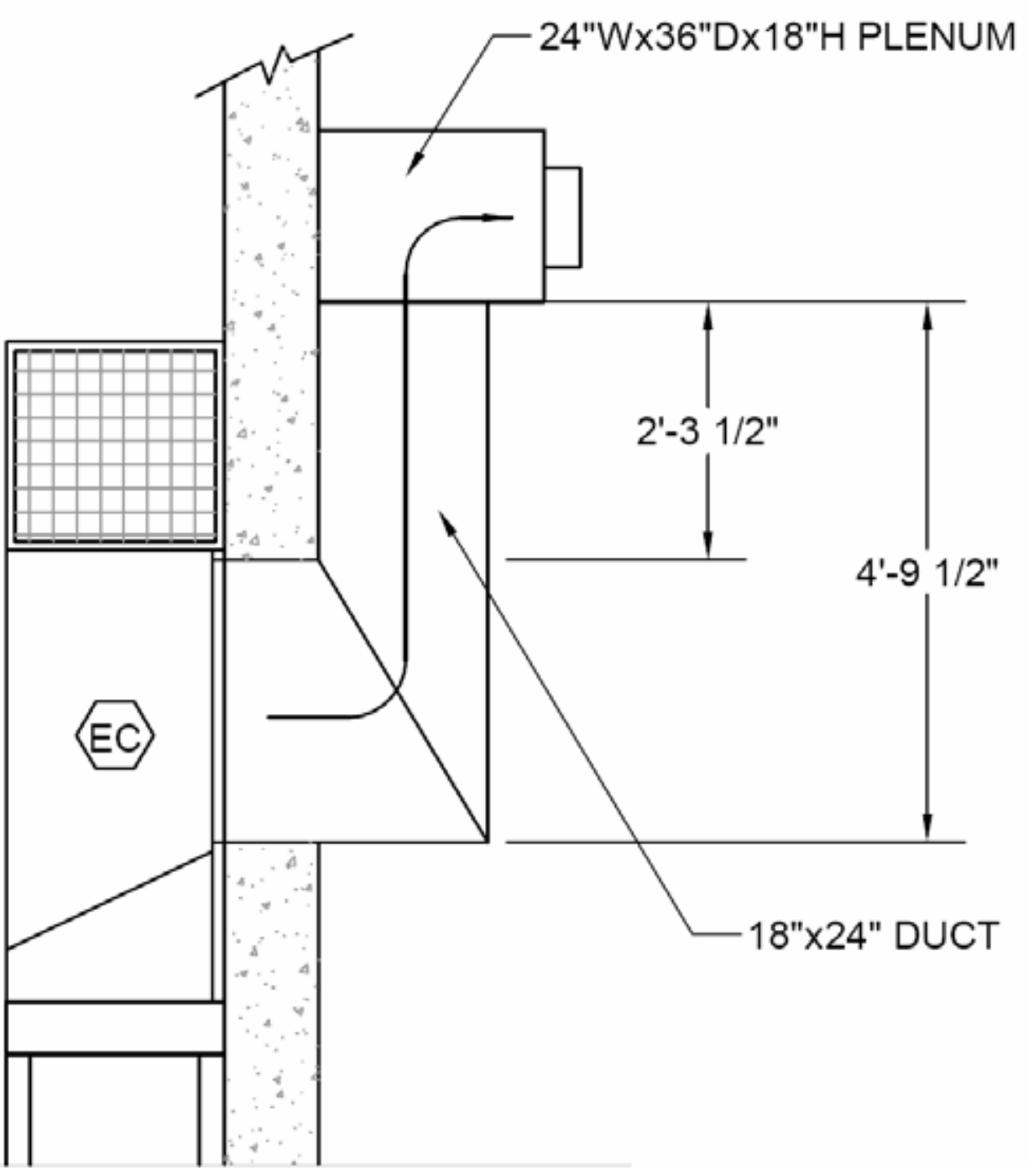

Figure 13. Supply plenum layout for Wagon OASys indirect/direct evaporative cooler 
At the lowest flow rate provided by the OASys, air velocities of roughly 50 FPM are realized that are nearly impossible to measure with a pressure-based sensor, such as the pitot tube traverse probes that were initially installed at the Wagon home. A hot-wire heat-transfer type airflow station was installed in order to make more accurate measurement of supply airflow rates across the manufacturer's specified airflow operating range (150 to 1,500 CFM). Because of the minimal ducting and lack of proper airflow development length (as illustrated in Figure 12) associated with the air-distribution system at the Wagon home, the outputs of both airflow sensors (Pitot tubes plus pressure transducer and the hot-wire airflow station) will be mapped against a fan-assisted flow hood to establish supply-air flow rates as accurately as possible. Datalogger programs will be revised to reflect the sensor output to fan-assisted flow-hood airflow maps in order to cover the range of continuously variable airflow rates that the OASys unit is capable of providing.

NREL will perform the mapping of the sensor outputs vs. know fan-flow rates during a site visit in the summer of 2006. Part of the difficulty in measuring the airflow for the OASys unit is that not all of the supply air provided by the OASys fan actually goes into the conditioned space via the supply air plenum. A portion of the fan airflow is exhausted to the outdoors via the indirect section of the cooler (Figure 1). The amount of airflow exhausted via the indirect section is affected by the static pressure on the supply side and changes with the continuously variable fan speed that the user selects. Capacity for the unit will be reported in two ways. The capacity relative to outdoor conditions will be determined by the change in enthalpy of the supply and outdoor-air conditions and the supply-air flowrate. Capacity relative to indoor conditions will be determined by the change in enthalpy of the supply and indoor conditions and the supply air flowrate. Measured values from the OASys specific sensors shown in Table 5 will be used in the calculations of cooling-system capacity for outdoor air or indoor air conditions (additional sensors within the home are part of the DEG datalogging system and are not detailed here). Cooling-system capacity coupled with the electrical energy measurements for the unit will allow use to calculate an EER for the unit. Measurements of supply air and indoor temperature and RH will allow us to calculate wet bulb effectiveness for the OASys.

\subsubsection{OASys Performance Data Results from Magna}

During a recent site visit, an airflow sensor was added to the long-term monitoring system installed at Magna Unit 1. With this additional data, the performance of the OASys unit under actual weather conditions can be determined. Although data collection is ongoing, only the data from August 18, 2005, until September 19, 2005, is analyzed here. During this time frame, 15minute data was collected including outdoor temperature, outdoor $\mathrm{RH}$, indoor temperatures (basement, first floor, and second floor), indoor RH (basement, first floor, and second floor), OASys energy consumption (Wh), OASys supply-duct pressure (Pa, used to calculate flow rate in the supply duct), supply-duct temperature, supply-duct RH, and makeup water-flow rate (gal/min).

During the 1-month data-analysis period, outdoor conditions varied considerably. Outdoor temperatures ranged from a maximum of $94^{\circ} \mathrm{F}$ to a minimum of $38^{\circ} \mathrm{F}$ and averaged $68^{\circ} \mathrm{F}$ during the data-analysis period. Relative humidity varied from a maximum of $82 \%$ to a minimum of $26 \%$ and averaged $48 \%$ during the data-analysis period. Figure 14 plots the outdoor conditions at Magna, Utah, during the data-analysis period. 


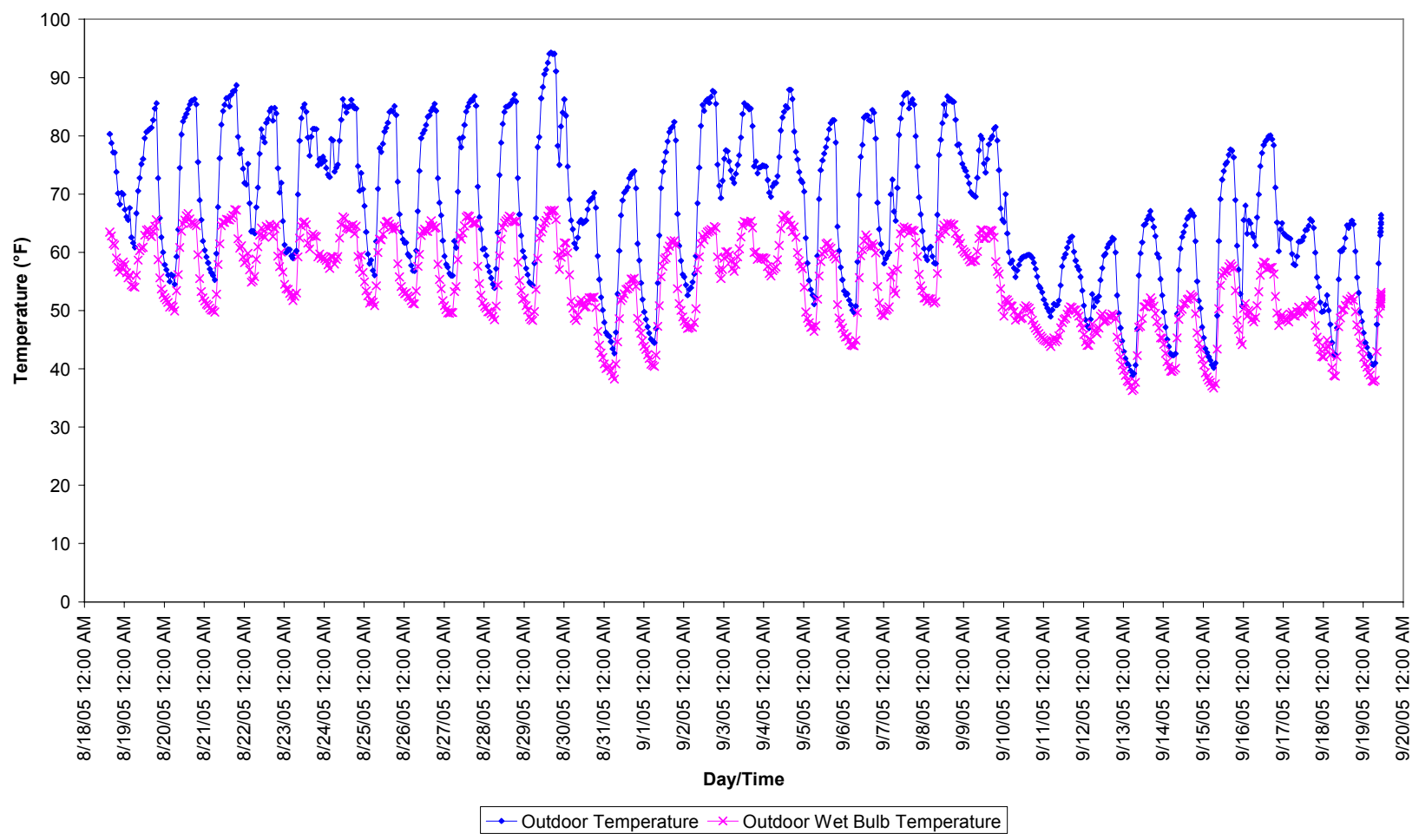

Figure 14. Outdoor conditions for Magna data-collection period

Inside the home, temperatures varied from a maximum of $79^{\circ} \mathrm{F}$ (second-story bedroom) to a minimum of $55^{\circ} \mathrm{F}$ (first floor) and averaged $68^{\circ} \mathrm{F}$ (all floors). Relative humidity varied from a maximum of $75 \%$ (first floor) to a minimum of $26 \%$ (first floor) and averaged $51 \%$ (all floors). 


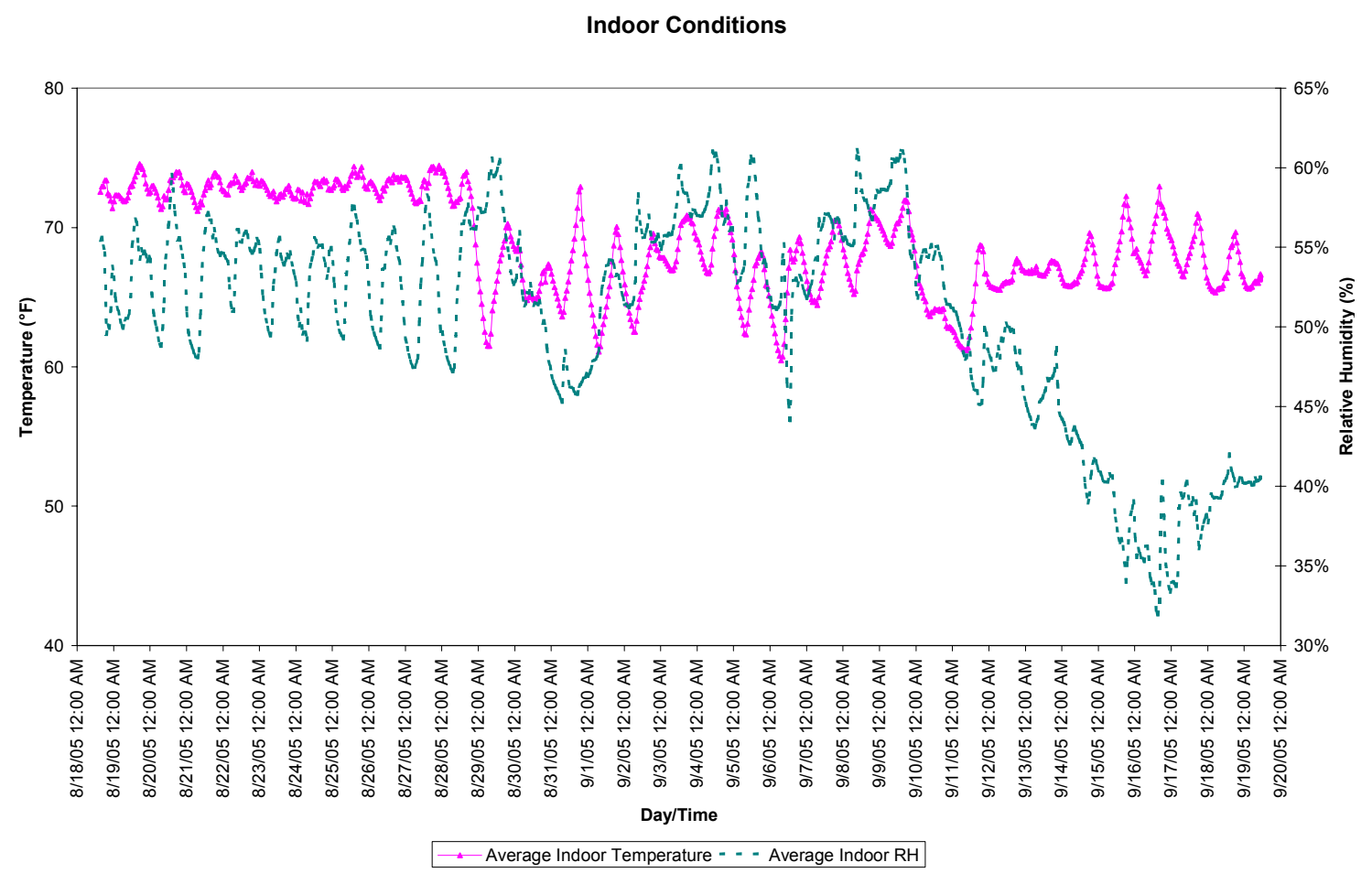

Figure 15. Indoor conditions for Magna data-collection period

Figure 15 shows that the OASys unit appears to keep the house comfortable even on days with outdoor temperatures as high as $95^{\circ} \mathrm{F}$.

The performance of the OASys unit during the data-analysis period shows a maximum EER of 153 , wet-bulb effectiveness of $136 \%$, cooling capacity of $29 \mathrm{kBtu} / \mathrm{hr}$ ( 2.4 tons), supply-air flow rate of 1,522 CFM, and energy consumption of $406 \mathrm{Wh}^{5}$ These maximum performance values measured at the site do not agree with NREL laboratory measurements that place the wet-bulb effectiveness for the OASys are between 103\% and 110\%. Currently, we believe that the outdoor temperature and RH sensor at Magna are giving false readings of outdoor conditions. Because of the malfunctioning outdoor temperature and RH sensor, these maximum values are overstating the performance of the OASys indirect/direct evaporative cooler at Magna. Figure 16 compares the site wet bulb temperature to the wet bulb temperature at Salt Lake City Airport.

\footnotetext{
${ }^{5}$ Maximum data values described here may not be coincident and are based on hourly data time steps; cooling capacity and EER values are relative to outdoor air conditions.
} 


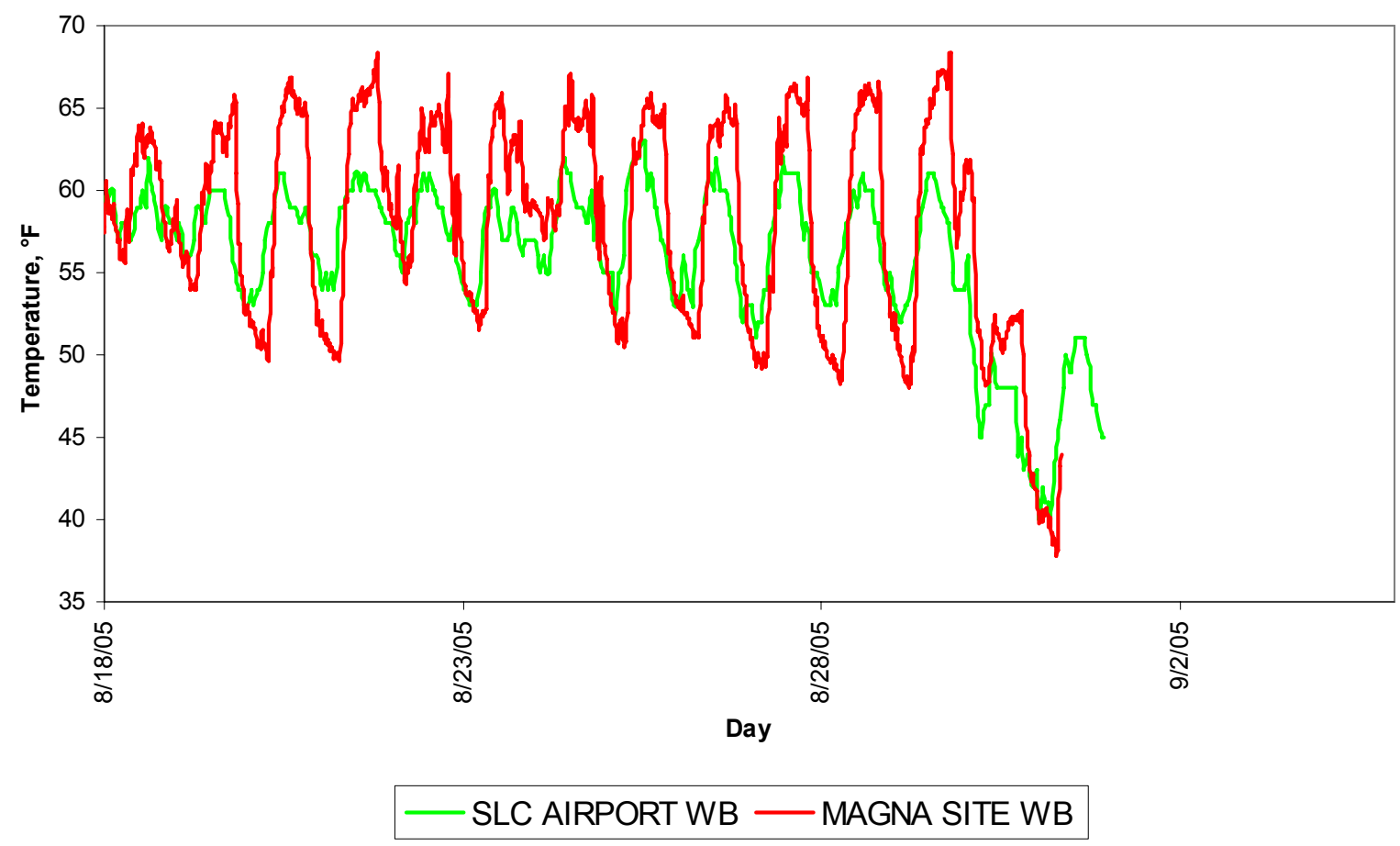

Figure 16. Outdoor wet-bulb temperature comparison for Magna data-collection period

During the data-collection period, the site wet bulb was found to be as much as $26^{\circ} \mathrm{F}$ higher and $10^{\circ} \mathrm{F}$ lower than wet-bulb temperatures measured at the airport. The Magna home site is roughly 15 miles from the Salt Lake City Airport, some of the difference in wet-bulb temperatures could be related to differences in microclimate. Another site visit is planned for the spring of 2006 to replace this sensor. Monitoring of this system will continue through the summer of 2006 with the hope that the field performance of the unit will compare more favorably to the measured performance in the lab. Figure 17 shows the EER of the OASys unit relative to exhaust air conditions ${ }^{6}$ with and without the furnace air-handler $(\mathrm{AH})$ fan considered. The prototype home at Magna, Utah, directs exhaust air through up ducts in the second floor ceiling into a shallow plenum below the attic insulation, referred to as the Dynamic Ceiling. Attic insulation is suspended above the shallow plenum with a wire-mesh screen that allows the exhaust air to flow through the attic insulation for an additional cooling effect. SWA staff is evaluating the Dynamic Ceiling concept at Magna Unit 1.

\footnotetext{
${ }^{6}$ All performance results presented relative to exhaust air conditions may not be representative of the actual performance of the OASys unit; the measurement of exhaust air temperature and RH is made at one up-duct location and may not characterize all of the exhaust air leaving the home. Performance results compared to outdoor conditions are not presented because of the malfunctioning outdoor sensors.
} 


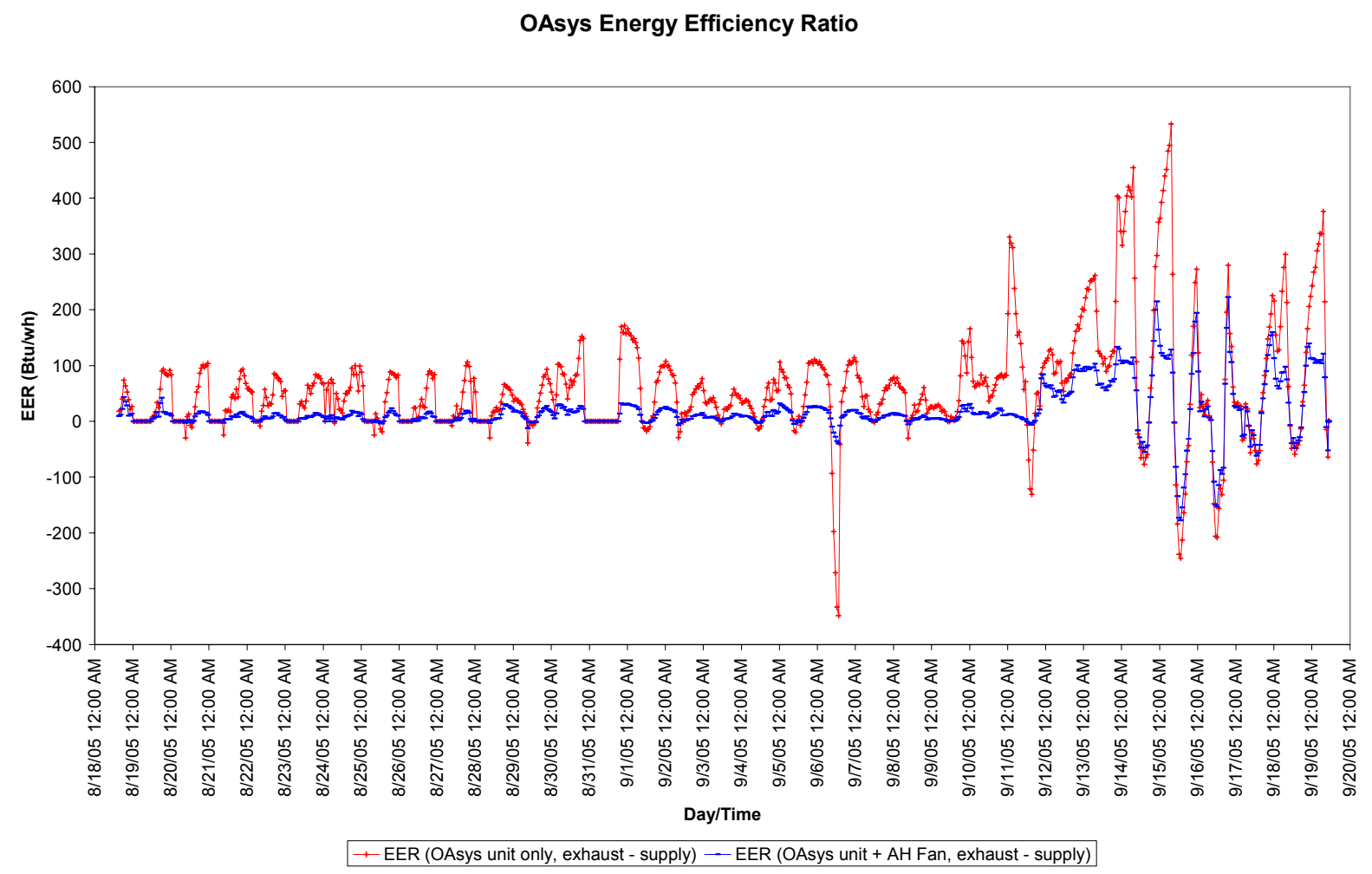

Figure 17. The EER values for OASys and OASys plus furnace AH fan

The intent of comparing the exhaust-air conditions to the supply-air conditions to establish EER and cooling capacity is to show performance data in a way that it may be compared to the performance metrics for direct-expansion refrigerant-based cooling systems. However, exhaust air does not always leave the home through intentional openings, such as up ducts. Therefore measurements of exhaust air temperature and $\mathrm{RH}$ is not representative of all the exhaust air leaving the home. In addition, the monitoring system for this home does not make exhaust-air temperature and $\mathrm{RH}$ measurements at each up duct. The monitoring system is limited to a single measurement of the exhaust-air conditions at one up duct; this is also problematic and may not represent the conditions at other up ducts.

During the site visit in early August 2005, we noted that the furnace air-handler fan was running continuously in fan-only mode. While this improves the uniformity of comfort conditions in the home, there is an energy-related penalty, as shown in Figure 18. The maximum energy consumed during the data-collection period by the OASys unit and the furnace air-handler fan is $840 \mathrm{Wh}-$ double that of the OASys unit by itself. 


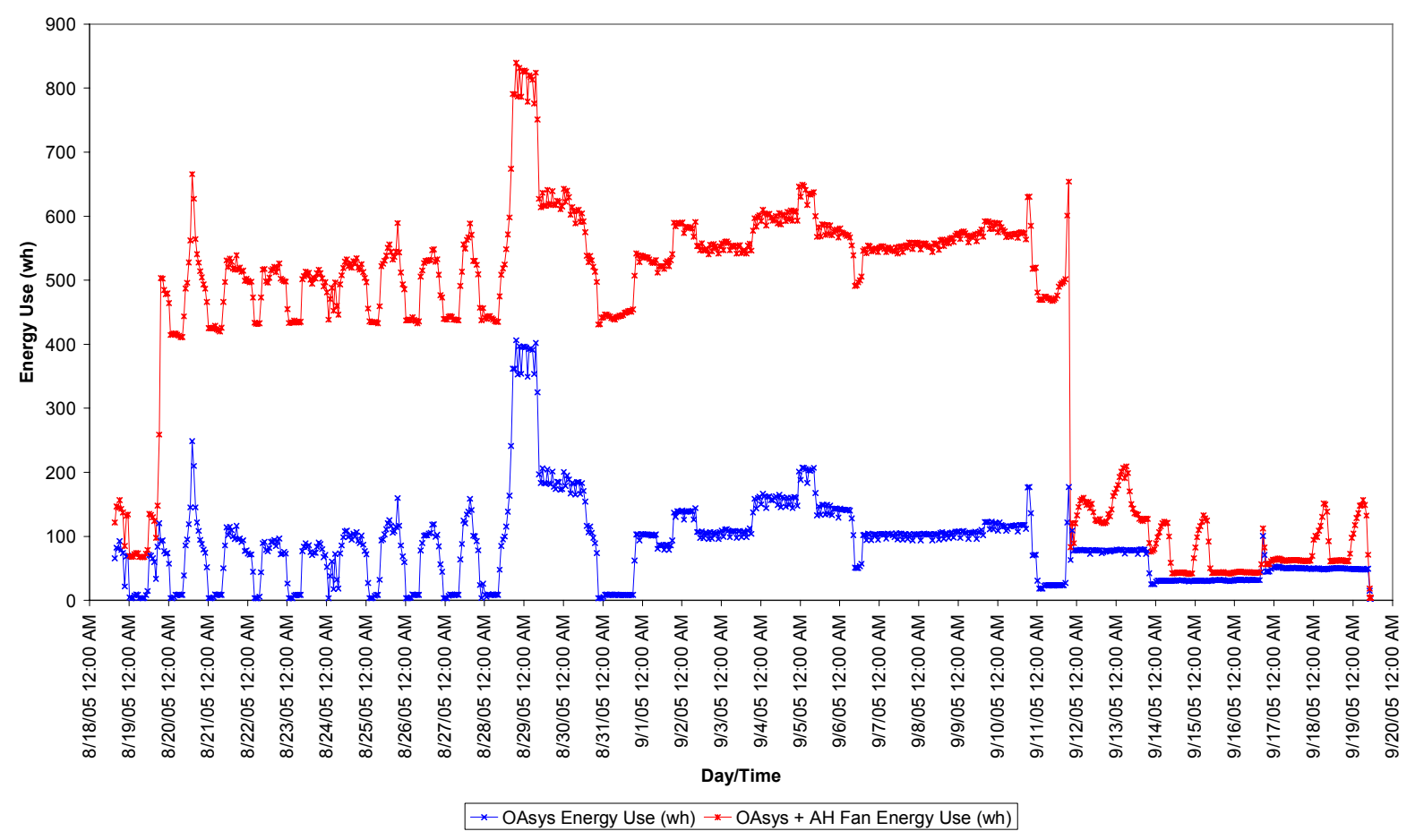

Figure 18. Energy use for OASys and OASys plus furnace AH fan

Wet-bulb effectiveness is commonly used to evaluate how closely an evaporative-cooling system approaches the outdoor (or entering) air wet-bulb temperature. Figure 19 plots wet-bulb effectiveness of the OASys unit for the data-collection period. Peak values are around $120 \%$ $130 \%$ wet-bulb effectiveness, which is somewhat higher than the more accurate measurements of $103 \%$ to $112 \%$ taken in the NREL laboratory. This is likely the result of the impaired outdoor temperature and $\mathrm{RH}$ sensor.

Because the OASys system is an indirect/direct type evaporative system, the whole-unit wet-bulb effectiveness can be greater than $100 \%$. Instrumentation was not placed such that the wet-bulb effectiveness of the indirect and direct sections could be evaluated separately. Instead, the permanent instrumentation on the OASys unit was placed such that whole-unit wet-bulb effectiveness could be evaluated. Note that negative effectiveness values occur. These occurred when the building heating system was on, and the OASys automatically provided cool outside air in ventilation mode. Because of the location of sensors in the supply duct, a slight heating of the air as a result of fan heat or heat addition to the supply duct may have raised the supply-air temperature slightly above the inlet-air temperature, causing the effectiveness to become negative when the OASys unit operates in ventilation mode. Because air is not significantly heated or cooled in this mode, the inlet and outlet air temperatures are very close to each other, so that slight errors in the temperature readings can also cause the effectiveness to be negative. 


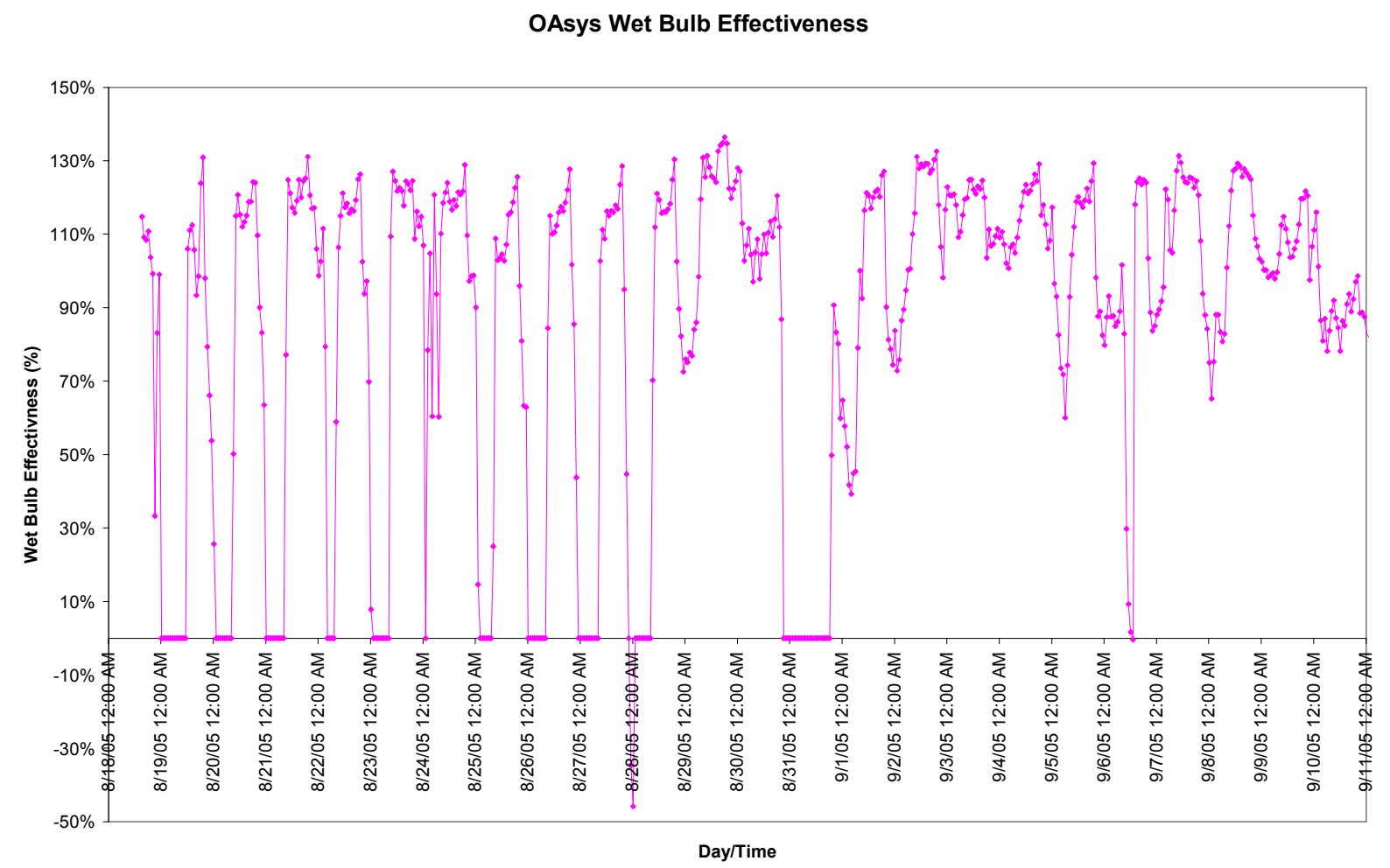

Figure 19. Wet-bulb effectiveness for the OASys unit at Magna

The cooling delivered by the OASys unit for the data analysis period is shown in Figure 20. The graph shows that the OASys unit is capable of capacities that are somewhat larger than the rated capacity of the unit at the manufacturer's test condition (see Appendix A for manufacturer's specifications). During the data-analysis period, the unit saw a maximum capacity of slightly more than 2 tons. This result may be influenced by the difficulty in accurately measuring the exhaust air conditions described previously. 


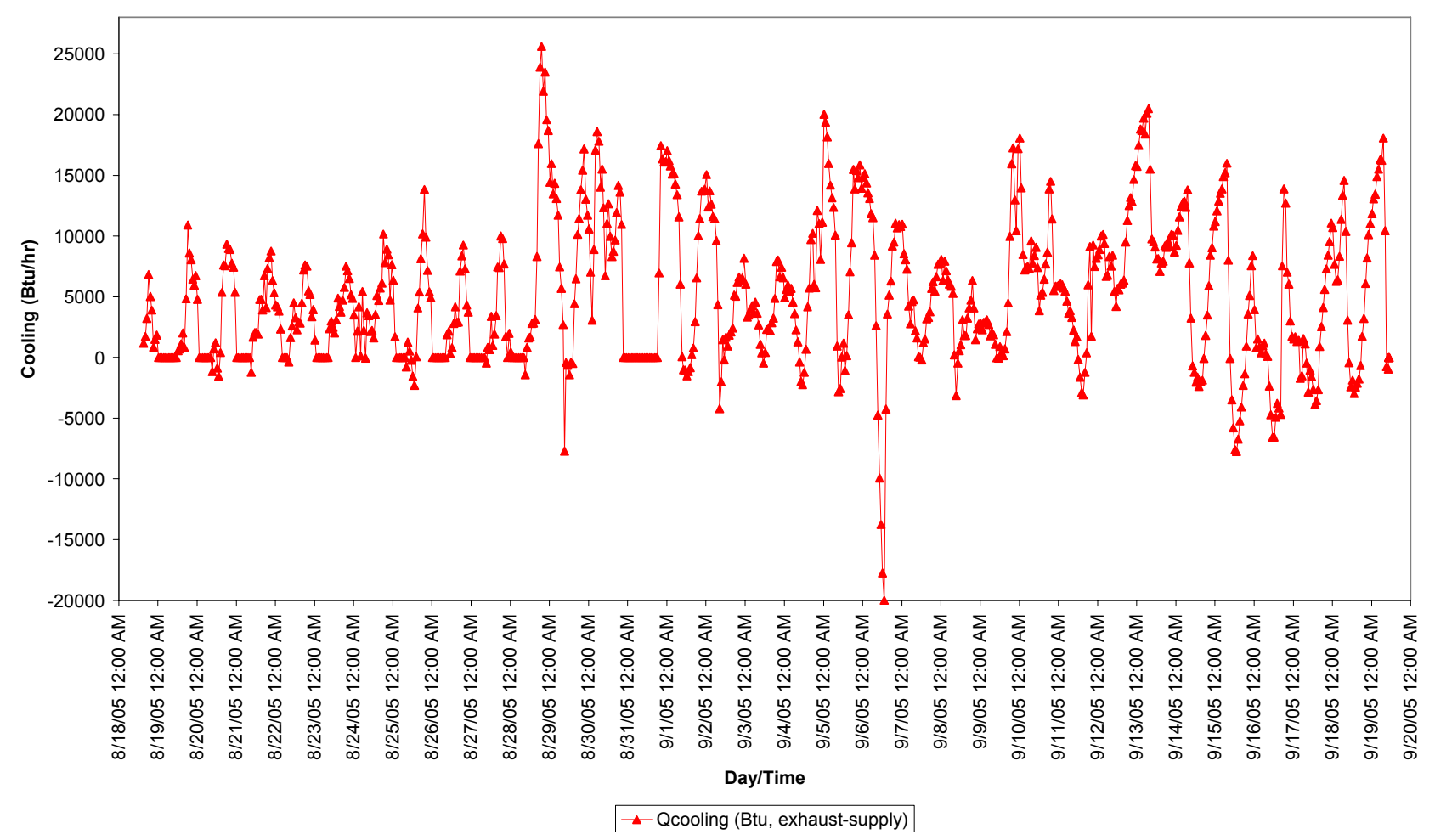

Figure 20. Cooling delivered by the OASys unit at Magna

Figures 17 through 20 all show negative values for the latter part of the data-collection period (9/12/05 - 9/19/05, negative EER and cooling delivered). Figure 21 shows the indoor, outdoor, and supply-air temperatures, along with the energy and water consumed by the OASys unit from $9 / 12 / 05$ to $9 / 19 / 05$. It shows the supply-air temperature tracking the outdoor air temperature when the unit is consuming no water during ventilation mode.

Figure 22 shows the energy consumed by the OASys unit and the energy consumed by the OASys unit plus the furnace AH fan.

From the Figure 22, it is clear that in the late evening of 9/11 the air-handler fan was taken out of "fan only" mode, which was helping to circulate the evaporatively cooled air in the home. At this point, the air-handler fan appears to cycle on periodically (this is shown wherever the two data series in Figure 22 deviate), which suggests that the furnace is responding to a heating load on the home. (The OASys and furnace have separate thermostats and can be operated simultaneously.) 
OASys Operation 9/12/05 - 9/19/05

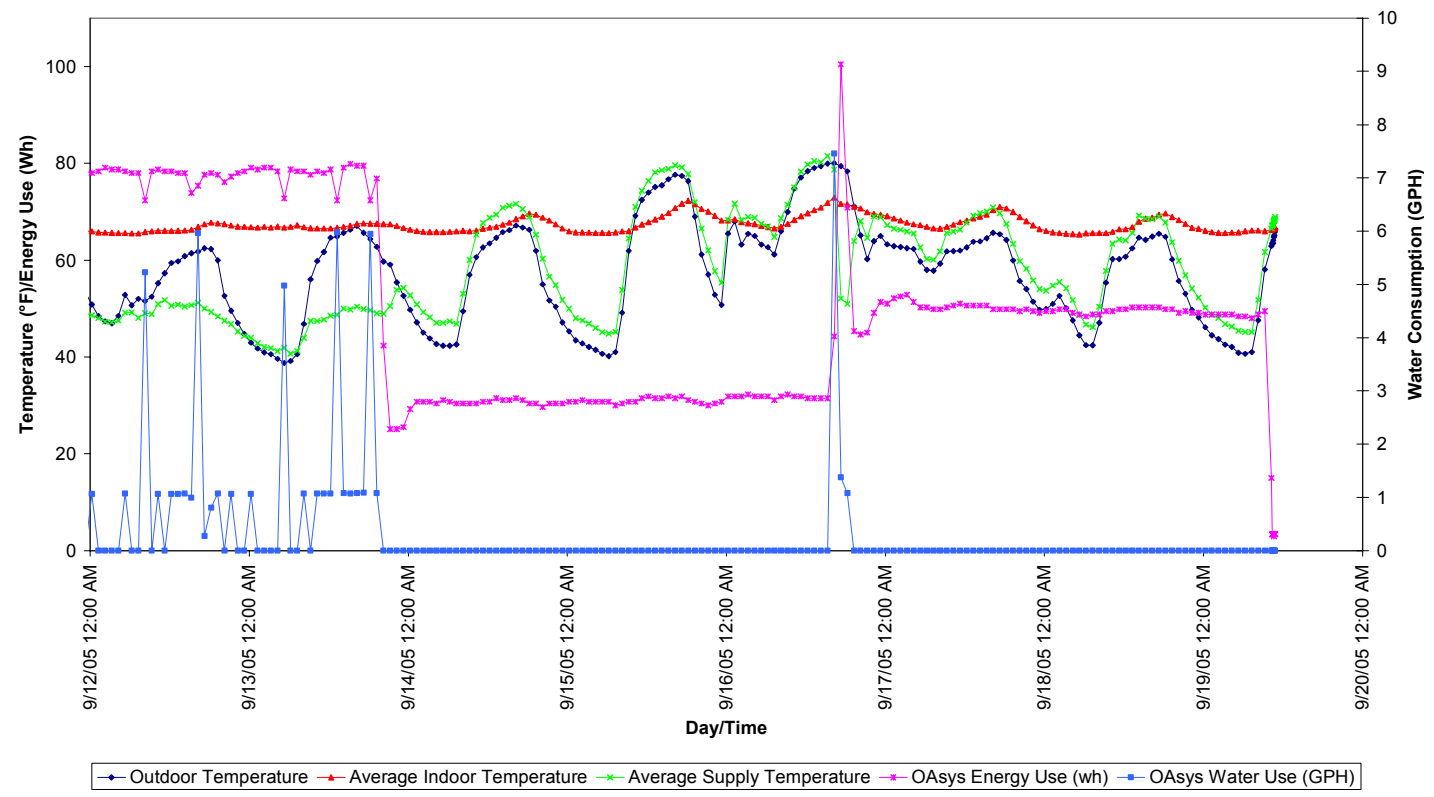

Figure 21. Performance during cool outdoor air temperatures

OASys Energy Use 9/11/05 - 9/19/05

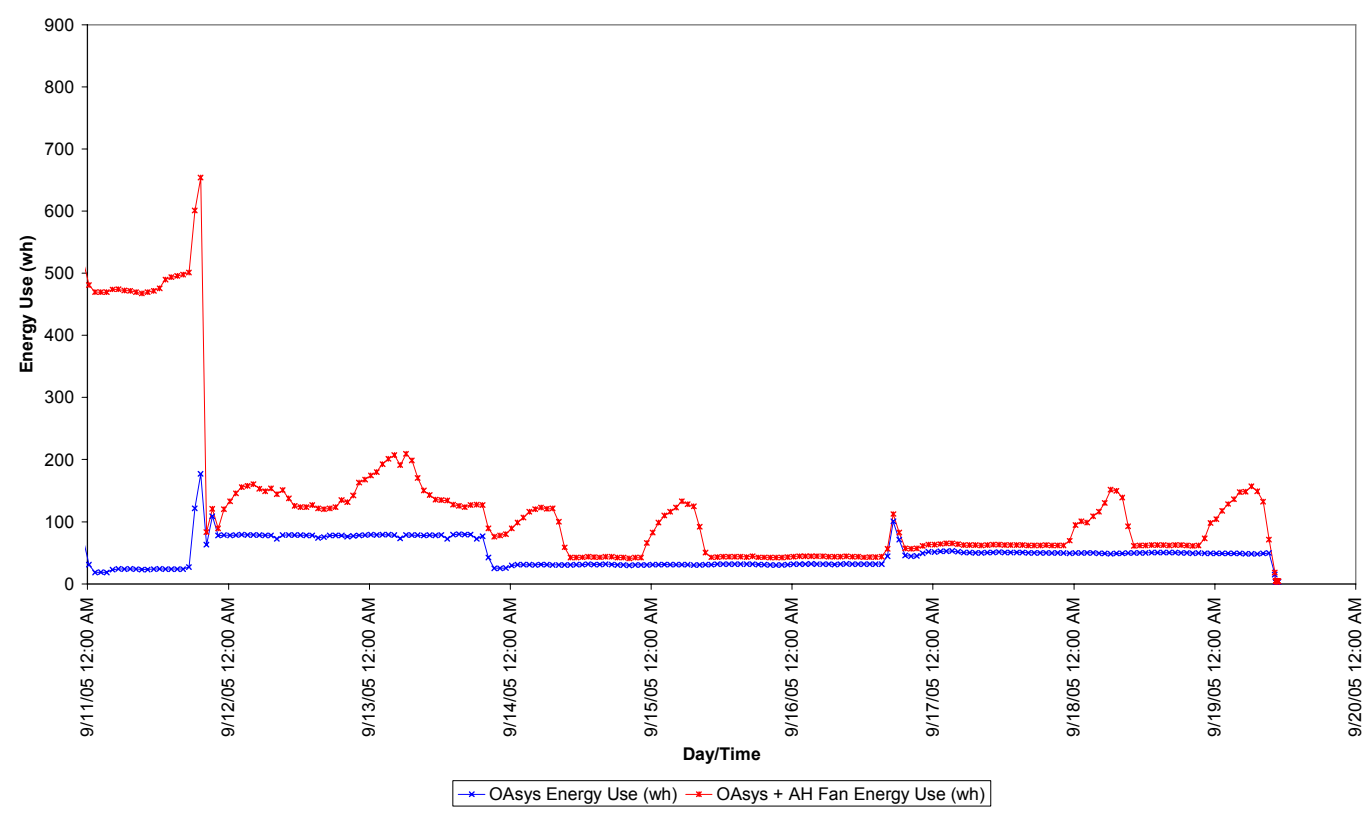

Figure 22. Energy consumed by the OASys unit and furnace AH fan for early September 
It appears that the OASys unit was running in ventilation mode during this timeframe when outdoor temperatures were cool, in order to cool the house, and was thus fighting the heating system. A follow-up visit or conversation with the homeowners may be necessary to better understand the interaction between the OASys and the heating system. It is not entirely clear that this mode of operation is unintended. Fresh-air ventilation can be provided with the OASys unit year round; however, ventilation during the winter months will add to the heating load.

\subsection{Freus Monitoring}

There is no permanent instrumentation of the Freus unit on Unit \#2 in Magna, Utah. One home in Borrego Springs, California, has a Freus unit that NREL intends to monitor in detail for longterm performance with the goal of answering the performance questions at the beginning of this section.

\subsubsection{Monitoring Plans for Borrego Springs Freus Unit}

At the DiGiorgio home, there are two separate data-collection systems. DEG has installed a datalogger that will be responsible for monitoring indoor temperature and $\mathrm{RH}$ at two locations within the house, attic and roof surface temperatures, floor slab circulation pump energy, PV energy collected, and house total energy use. When normal compressor cooling is not called for, the evaporative condenser will be used as a cooling tower; water from the sump of the Freus will be circulated to cool the concrete floor slab. The DEG datalogger will be configured to monitor the cooling delivered via the floor slab. NREL has intends to install permanent instrumentation to monitor the performance of the Freus system, including air-handler fan energy, condenser fan energy, compressor energy, total energy for the condensing unit, the cooling delivered to the conditioned space, the evaporative pump energy consumption by subtraction, and the water consumption of the outdoor unit.

We will also monitor ambient temperature and humidity conditions in the vicinity of the condenser, condenser air-intake temperature and RH, condenser exhaust-air temperature and RH, outdoor-air damper status, and condenser fan status. A one-time measurement of condenser fan flow rate will be performed. A list of measurements for which NREL for is contained in Table 6. These measurements should allow us to calculate the EER, cooling capacity, water consumption, and electrical energy consumption for the Freus in its normal cooling mode under a variety of weather conditions. When combined with the DEG data, we should be able to determine EER, cooling capacity, water consumption, and electrical energy consumption for the Freus in its floor slab-cooling mode.

In addition to performance monitoring, there are also concerns about the impact of water quality on outdoor coil performance. Additional monitoring points may be added to measure the pressure drop across the demister for a long-term look at scaling issues. Details regarding additional sensors are still under discussion at NREL.

The approach for measuring some of the variables shown in Table 6 is fairly straightforward as the sensors are connected directly to a Campbell CR10X datalogger (www.campbellsci.com/index.cfm) provided by NREL, for long-term data collection. Sensors listed in Table 6 were provided and installed by NREL. 
Table 6. Instrumentation for Freus Unit

\begin{tabular}{|c|c|c|c|c|c|c|c|}
\hline Data Required & Measurement & Sensor Type & Sensor Part \# & Sensor Accuracy & Installed Location & Quantity & More Info \\
\hline \multirow{2}{*}{$\begin{array}{l}\text { AH fan Energy } \\
\text { consumption }\end{array}$} & \multirow{2}{*}{$\begin{array}{l}\text { Continuously } \\
\text { monitored Watt- } \\
\text { hour Totalization } \\
\text { meter }\end{array}$} & $\begin{array}{l}\text { True RMS AC watt-hour } \\
\text { transducer with pulse } \\
\text { output }\end{array}$ & WNA-1P-240-P & $\begin{array}{l}0.45 \% \text { of reading }+ \\
0.05 \% \text { of full scale } \\
\text { through } 25 \text { th } \\
\text { harmonic }\end{array}$ & $\begin{array}{l}\text { Installed within to } \\
\text { circuit-breaker panel }\end{array}$ & 1 & \multirow{2}{*}{ www.ccontrolsys.com } \\
\hline & & Split-core CT (15 amp) & CTS-0750-015 & $\begin{array}{l}\text { Accuracy } \pm 1 \% \\
\text { from } 10 \% \text { to } 130 \% \\
\text { of rated current }\end{array}$ & $\begin{array}{l}\text { Installed on A- and } \\
\text { B-phase hot leads at } \\
\text { AH fan circuit } \\
\text { breaker }\end{array}$ & 2 & \\
\hline $\begin{array}{l}\text { Condensing unit } \\
\text { total energy } \\
\text { consumption }\end{array}$ & $\begin{array}{l}\text { Continuously } \\
\text { monitored Watt- } \\
\text { hour Totalization } \\
\text { meter }\end{array}$ & $\begin{array}{l}\text { True RMS AC watt-hour } \\
\text { transducer with pulse } \\
\text { output }\end{array}$ & WNA-1P-240-P & $\begin{array}{l}0.45 \% \text { of reading }+ \\
0.05 \% \text { of full scale } \\
\text { through } 25 \text { th } \\
\text { harmonic }\end{array}$ & $\begin{array}{l}\text { Small electrical box } \\
\text { installed on Freus } \\
\text { unit }\end{array}$ & 1 & www.ccontrolsys.com \\
\hline \multirow{2}{*}{$\begin{array}{l}\text { Condenser fan } \\
\text { energy } \\
\text { consumption }\end{array}$} & \multirow{2}{*}{$\begin{array}{l}\text { Continuously } \\
\text { monitored Watt- } \\
\text { hour Totalization } \\
\text { meter }\end{array}$} & $\begin{array}{l}\text { True RMS AC watt-hour } \\
\text { transducer with pulse } \\
\text { output }\end{array}$ & WNA-1P-240-P & $\begin{array}{l}0.45 \% \text { of reading }+ \\
0.05 \% \text { of full scale } \\
\text { through } 25 \text { th } \\
\text { harmonic }\end{array}$ & $\begin{array}{l}\text { Small electrical box } \\
\text { installed on Freus } \\
\text { unit }\end{array}$ & 1 & \multirow[b]{2}{*}{ www.ccontrolsys.com } \\
\hline & & Split-core CT (15 amp) & CTS-0750-015 & $\begin{array}{l}\text { Accuracy } \pm 1 \% \\
\text { from } 10 \% \text { to } 130 \% \\
\text { of rated current }\end{array}$ & $\begin{array}{l}\text { Installed on hot } \\
\text { leads to condenser } \\
\text { fan within } \\
\text { condensing-unit } \\
\text { case }\end{array}$ & 1 & \\
\hline
\end{tabular}


Table 6 (continued). Instrumentation for Freus Unit

\begin{tabular}{|c|c|c|c|c|c|c|c|}
\hline Data Required & Measurement & Sensor Type & Sensor Part \# & Sensor Accuracy & Installed Location & Quantity & More Info \\
\hline \multirow{2}{*}{$\begin{array}{l}\text { Compressor } \\
\text { energy } \\
\text { consumption }\end{array}$} & \multirow{2}{*}{$\begin{array}{l}\text { Continuously } \\
\text { monitored Watt-hour } \\
\text { Totalization meter }\end{array}$} & $\begin{array}{l}\text { True RMS AC } \\
\text { watt-hour } \\
\text { transducer with } \\
\text { pulse output }\end{array}$ & WNA-1P-240-P & $\begin{array}{l}0.45 \% \text { of reading } \\
+0.05 \% \text { of full } \\
\text { scale through } \\
25 \text { th harmonic }\end{array}$ & $\begin{array}{l}\text { Small electrical box } \\
\text { installed on Freus unit }\end{array}$ & 1 & \multirow{2}{*}{ www.ccontrolsys.com } \\
\hline & & $\begin{array}{l}\text { Split-core CT (15 } \\
\text { amp) }\end{array}$ & CTS-0750-015 & $\begin{array}{l}\text { Accuracy } \pm 1 \% \\
\text { from } 10 \% \text { to } \\
130 \% \text { of rated } \\
\text { current }\end{array}$ & $\begin{array}{l}\text { Installed on hot leads } \\
\text { to compressor within } \\
\text { condensing unit case }\end{array}$ & 2 & \\
\hline $\begin{array}{l}\text { Evaporative } \\
\text { system pump } \\
\text { energy } \\
\text { consumption }\end{array}$ & \multicolumn{7}{|c|}{ Not measured - data obtained by subtracting the compressor and condenser fan energy from the condensing unit total energy } \\
\hline $\begin{array}{l}\text { Evaporative } \\
\text { sump system } \\
\text { water inlet flow } \\
\text { rate }\end{array}$ & $\begin{array}{l}\text { Continuously } \\
\text { monitored water flow } \\
\text { rate }\end{array}$ & $\begin{array}{l}\text { Paddle wheel } \\
\text { flowmeter with pulse } \\
\text { output }\end{array}$ & FTB-4105A-P & $\begin{array}{l} \pm 1 \% \text { of reading for } \\
0.3-9 L P M, 8000 \\
\text { pulses/L, } 1 / 2 \text {-in. NPT }\end{array}$ & $\begin{array}{l}\text { At water inlet for float } \\
\text { valve on Freus cabinet }\end{array}$ & 1 & www.omega.com \\
\hline \multirow{2}{*}{$\begin{array}{l}\text { Condenser fan } \\
\text { flow rate }\end{array}$} & \multirow{2}{*}{$\begin{array}{l}\text { One-time pressure } \\
\text { matching and flow } \\
\text { measurement of } \\
\text { condenser-fan } \\
\text { operation with blower- } \\
\text { door fan }\end{array}$} & Calibrated fan & & $\begin{array}{l}+/ 3 \% \\
\text { (using DG-700 or } \\
\text { DG-3) }\end{array}$ & $\begin{array}{l}\text { Temporary install on } \\
\text { site-built box above } \\
\text { condenser fan outlet }\end{array}$ & 1 & $\begin{array}{l}\frac{\text { www.energyconservator }}{\text { y.com/download/bdbroc }} \\
\underline{\text { hure.pdf }}\end{array}$ \\
\hline & & $\begin{array}{l}\text { Pressure and Flow } \\
\text { gauge }\end{array}$ & $\begin{array}{l}\text { DG-700 or } \\
\text { |DG-3 pressure } \\
\text { and flow gauge }\end{array}$ & $\begin{array}{l} \pm 1 \% \text { of reading } \\
\text { from }-1,250 \text { to } \\
+1,250 \text { Pascals, or } \\
-5 \text { to }+5 \text { inwc }\end{array}$ & $\begin{array}{l}\text { Handheld for one-time } \\
\text { measurement }\end{array}$ & \multirow[t]{2}{*}{1} & $\begin{array}{l}\frac{\text { www.energyconservator }}{\text { y.com/download/dg700b }} \\
\underline{\text { rochure.pdf }}\end{array}$ \\
\hline $\begin{array}{l}\text { Condenser fan } \\
\text { operation }\end{array}$ & $\begin{array}{l}\text { Use milivolt output } \\
\text { from DC-CT to } \\
\text { indicate fan operation } \\
\text { and infer fan flow over } \\
\text { time (assume that } \\
\text { condenser fan flow is } \\
\text { constant at given } \\
\text { power level) }\end{array}$ & $\begin{array}{l}\text { DC current } \\
\text { transducer }\end{array}$ & & & $\begin{array}{l}\text { Installed on hot lead to } \\
\text { condenser fan within } \\
\text { condensing unit case }\end{array}$ & & \\
\hline
\end{tabular}


Table 6 (continued). Instrumentation for Freus Unit

\begin{tabular}{|c|c|c|c|c|c|c|c|}
\hline $\begin{array}{l}\text { Data } \\
\text { Required }\end{array}$ & Measurement & Sensor Type & Sensor Part \# & Sensor Accuracy & Installed Location & Quantity & More Info \\
\hline \multirow{2}{*}{$\begin{array}{l}\text { Condenser fan } \\
\text { exhaust-air } \\
\text { absolute } \\
\text { humidity }\end{array}$} & $\begin{array}{l}\text { Continuously } \\
\text { monitored exhaust- } \\
\text { air dry-bulb } \\
\text { temperature }\end{array}$ & $\begin{array}{l}\text { Resistance temperature } \\
\text { device (thermistor) }\end{array}$ & \multirow{2}{*}{ Vaisala HMP-45A } & $\begin{array}{l} \pm 0.36^{\circ} \mathrm{F} @ 68^{\circ} \mathrm{F}, \text { see } \\
\text { online specs for full } \\
\text { accuracy specs }\end{array}$ & \multirow{2}{*}{$\begin{array}{l}\text { Installed in sampling } \\
\text { tube with vacuum } \\
\text { pump on condenser- } \\
\text { fan exhaust grill }\end{array}$} & \multirow{2}{*}{1} & \multirow{2}{*}{ www.vaisala.com } \\
\hline & $\begin{array}{l}\text { Continuously } \\
\text { monitored exhaust- } \\
\text { air RH }\end{array}$ & $\begin{array}{l}\text { Variable-capacitance- } \\
\text { type RH sensor }\end{array}$ & & $\begin{array}{l}0-90 \% \mathrm{RH}= \pm 2 \%, 90 \%- \\
100 \% \pm 3 \% @ 68^{\circ} \mathrm{F}, \text { see } \\
\text { online specs for full } \\
\text { accuracy specs }\end{array}$ & & & \\
\hline $\begin{array}{l}\text { Condenser fan } \\
\text { exhaust-air } \\
\text { dry-bulb } \\
\text { temperature }\end{array}$ & $\begin{array}{l}\text { Continuously } \\
\text { monitored outdoor-air } \\
\text { dry-bulb temperature }\end{array}$ & $\begin{array}{l}\text { Twisted, shielded, } \\
\text { stranded, special limits } \\
\text { of error type-T } \\
\text { thermocouple, } \\
\text { Copper/Copper- } \\
\text { Constantan-Nickel }\end{array}$ & $\begin{array}{l}\text { TT-T-24S-TWSH- } \\
\text { SLE-1000 } \\
(1,000-f t \text { spool })\end{array}$ & $0.5^{\circ} \mathrm{C}$ or $0.4 \%$ & $\begin{array}{l}\text { Six thermocouples } \\
\text { installed in parallel on } \\
\text { condenser-fan } \\
\text { exhaust grill adjacent } \\
\text { to sampling tube }\end{array}$ & 6 & www.omega.com \\
\hline \multirow{2}{*}{$\begin{array}{l}\text { Condenser fan } \\
\text { intake-air } \\
\text { absolute } \\
\text { humidity }\end{array}$} & $\begin{array}{l}\text { Continuously } \\
\text { monitored exhaust- } \\
\text { air dry-bulb } \\
\text { temperature }\end{array}$ & $\begin{array}{l}\text { Resistance temperature } \\
\text { device (thermistor) }\end{array}$ & \multirow{2}{*}{ Vaisala HMP-45A } & $\begin{array}{l} \pm 0.36^{\circ} \mathrm{F} @ 68^{\circ} \mathrm{F}, \text { see } \\
\text { online specs for full } \\
\text { accuracy specs }\end{array}$ & \multirow{2}{*}{$\begin{array}{l}\text { Installed in custom } \\
\text { shield behind } \\
\text { condenser air intake } \\
\text { grill }\end{array}$} & \multirow{2}{*}{1} & \multirow{2}{*}{ www.vaisala.com } \\
\hline & $\begin{array}{l}\text { Continuously } \\
\text { monitored exhaust- } \\
\text { air RH }\end{array}$ & $\begin{array}{l}\text { Variable-capacitance- } \\
\text { type RH sensor }\end{array}$ & & $\begin{array}{l}0-90 \% \text { RH }= \pm 2 \%, 90 \%- \\
100 \% \pm 3 \% @ 68^{\circ} \mathrm{F}, \text { see } \\
\text { online specs for full } \\
\text { accuracy specs }\end{array}$ & & & \\
\hline $\begin{array}{l}\text { Condenser fan } \\
\text { Intake-air dry- } \\
\text { bulb } \\
\text { temperature }\end{array}$ & $\begin{array}{l}\text { Continuously } \\
\text { monitored outdoor-air } \\
\text { dry-bulb temperature }\end{array}$ & $\begin{array}{l}\text { Twisted, shielded, } \\
\text { stranded, special limits } \\
\text { of error type-T } \\
\text { thermocouple, } \\
\text { Copper/Copper- } \\
\text { Constantan-Nickel }\end{array}$ & $\begin{array}{l}\text { TT-T-24S-TWSH- } \\
\text { SLE-1000 } \\
(1,000-f t \text { spool })\end{array}$ & $0.5^{\circ} \mathrm{C}$ or $0.4 \%$ & $\begin{array}{l}\text { Six thermocouples } \\
\text { installed in parallel } \\
\text { behind condenser air } \\
\text { intake grill }\end{array}$ & 6 & www.omega.com \\
\hline
\end{tabular}


Table 6 (continued). Instrumentation for Freus Unit

\begin{tabular}{|c|c|c|c|c|c|c|c|}
\hline Data Required & Measurement & Sensor Type & Sensor Part \# & Sensor Accuracy & Installed Location & Quantity & More Info \\
\hline \multirow[b]{2}{*}{$\mathrm{AH}$ fan-flow rate } & \multirow{2}{*}{$\begin{array}{l}\text { Continuously } \\
\text { monitored return-duct } \\
\text { pressure differential }\end{array}$} & Pitot tube traverse & $\begin{array}{l}\text { VOLU-probe } 3 \\
\text { removable pitot } \\
\text { airflow traverse } \\
\text { probe }\end{array}$ & $2 \%$ of actual flow & $\begin{array}{l}\text { Directly downstream } \\
\text { of } \mathrm{AH} \text { filter on } \\
\text { return/outdoor air } \\
\text { intake }\end{array}$ & 1 & \\
\hline & & Pressure transducer & $\begin{array}{l}\text { Veltron } 2500 \\
\text { Plus } 0-0.05 \text {-in. } \\
\text { wc span }\end{array}$ & $\begin{array}{l}0.25 \% \text { of natural span, } \\
\text { including non-linearity, } \\
\text { hysteresis, } \\
\text { dead band, and non- } \\
\text { repeatability. }\end{array}$ & $\begin{array}{l}\text { Mounted on side of } \\
\text { supply plenum }\end{array}$ & 1 & $\underline{\text { www.airmonitor.com }}$ \\
\hline $\begin{array}{l}\text { Return-air } \\
\text { temperature and } \\
\text { RH }\end{array}$ & $\begin{array}{l}\text { Continuously } \\
\text { monitored return-air } \\
\text { dry-bulb temperature } \\
\text { Continuously } \\
\text { monitored return-air } \\
\mathrm{RH}\end{array}$ & $\begin{array}{l}\text { Resistance } \\
\text { temperature device } \\
\text { (thermistor) } \\
\text { Variable- } \\
\text { capacitance-type } \\
\text { RH sensor }\end{array}$ & $\begin{array}{l}\text { Vaisala } \\
\text { HMD60Y }\end{array}$ & $\begin{array}{l} \pm 0.2^{\circ} \mathrm{F} @ 68^{\circ} \mathrm{F}, \text { see } \\
\text { online specs for full } \\
\text { accuracy specs } \\
0-100 \% \mathrm{RH}= \pm 2 \% @ \\
68^{\circ} \mathrm{F}, \text { see online specs } \\
\text { for full accuracy specs }\end{array}$ & $\begin{array}{l}\text { Return/outdoor air } \\
\text { intake duct upstream } \\
\text { of } \mathrm{AH} \text { filter }\end{array}$ & 1 & www.vaisala.com \\
\hline $\begin{array}{l}\text { Supply-air } \\
\text { temperature and } \\
\text { RH }\end{array}$ & $\begin{array}{l}\text { Continuously } \\
\text { monitored supply-air } \\
\text { dry-bulb temperature } \\
\text { Continuously } \\
\text { monitored supply-Air } \\
\text { RH }\end{array}$ & $\begin{array}{l}\text { Resistance } \\
\text { temperature device } \\
\text { (thermistor) } \\
\text { Variable- } \\
\text { capacitance-type } \\
\text { RH sensor }\end{array}$ & $\begin{array}{l}\text { Vaisala } \\
\text { HMD60Y }\end{array}$ & $\begin{array}{l} \pm 0.2^{\circ} \mathrm{F} @ 68^{\circ} \mathrm{F}, \text { see } \\
\text { online specs for full } \\
\text { accuracy specs } \\
0-100 \% \mathrm{RH}= \pm 2 \% @ \\
68^{\circ} \mathrm{F}, \text { see online specs } \\
\text { for full accuracy specs }\end{array}$ & $\begin{array}{l}\text { Supply duct, placed at } \\
\text { each supply-air main } \\
\text { trunk off supply } \\
\text { plenum }\end{array}$ & 3 & $\underline{\text { www.vaisala.com }}$ \\
\hline
\end{tabular}


Table 6 (continued). Instrumentation for Freus Unit

\begin{tabular}{|c|c|c|c|c|c|c|c|}
\hline Data Required & Measurement & Sensor Type & Sensor Part \# & Sensor Accuracy & Installed Location & Quantity & More Info \\
\hline $\begin{array}{l}\text { AH fan speed } \\
\text { (fan flow rate) }\end{array}$ & $\begin{array}{l}\text { Continuously } \\
\text { monitored fan RPM }\end{array}$ & $\begin{array}{l}\text { Pulse output } \\
\text { from GE fan } \\
\text { motor }\end{array}$ & NA & NA & $\begin{array}{l}\text { Sensor leads at GE fan } \\
\text { motor }\end{array}$ & & \\
\hline \multirow{2}{*}{$\begin{array}{l}\text { Condensing-unit } \\
\text { ambient-air } \\
\text { absolute } \\
\text { humidity }\end{array}$} & $\begin{array}{l}\text { Continuously } \\
\text { monitored outdoor- } \\
\text { air dry-bulb } \\
\text { temperature }\end{array}$ & $\begin{array}{l}\text { Resistance } \\
\text { temperature } \\
\text { device } \\
\text { (thermistor) }\end{array}$ & \multirow{2}{*}{ Vaisala HMP-50 } & $\begin{array}{l} \pm 1.1^{\circ} \mathrm{F} @ 68^{\circ} \mathrm{F} \\
\text { see online specs } \\
\text { for full accuracy } \\
\text { specs }\end{array}$ & \multirow{2}{*}{$\begin{array}{l}\text { Mounted on fence } \\
\text { surrounding condensing } \\
\text { unit, shielded, naturally } \\
\text { aspirated }\end{array}$} & \multirow{2}{*}{1} & \multirow{2}{*}{$\underline{\text { www.vaisala.com }}$} \\
\hline & $\begin{array}{l}\text { Continuously } \\
\text { monitored outdoor- } \\
\text { air RH }\end{array}$ & $\begin{array}{l}\text { Variable- } \\
\text { capacitance-type } \\
\text { RH sensor }\end{array}$ & & $\begin{array}{l}0-90 \% \text { RH }= \pm 3 \% \\
90-98 \% \pm 5 \%, \text { see } \\
\text { online specs for } \\
\text { full accuracy specs }\end{array}$ & & & \\
\hline $\begin{array}{l}\text { Condensing -nit } \\
\text { ambient-air dry- } \\
\text { bulb temperature }\end{array}$ & $\begin{array}{l}\text { Continuously } \\
\text { monitored outdoor - } \\
\text { air dry-bulb } \\
\text { temperature }\end{array}$ & $\begin{array}{l}\text { Twisted, } \\
\text { shielded, } \\
\text { stranded, special } \\
\text { limits of error } \\
\text { type-T } \\
\text { thermocouple, } \\
\text { Copper/Copper- } \\
\text { Constantan- } \\
\text { Nickel }\end{array}$ & $\begin{array}{l}\text { TT-T-24S- } \\
\text { TWSH-SLE- } \\
1000 \\
(1000-\text { ft spool) }\end{array}$ & $0.5^{\circ} \mathrm{C}$ or $0.4 \%$ & $\begin{array}{l}\text { Mounted on fence } \\
\text { surrounding condensing } \\
\text { unit, shielded, forced } \\
\text { aspiration }\end{array}$ & 2 & www.omega.com \\
\hline
\end{tabular}


Data is logged in 15-minute intervals and is a combination of 15-minute averages or totalizations depending on the measurement. Measuring the airflow provided by the Nightbreeze ${ }^{7}$ air-handler unit is proving to be difficult because of its ability to provide ventilation air at a flow rate of approximately $200 \mathrm{CFM}$. The return duct where the airflow sensors are located has a square cross section of 20x21 in. and is pictured in Figure 23.

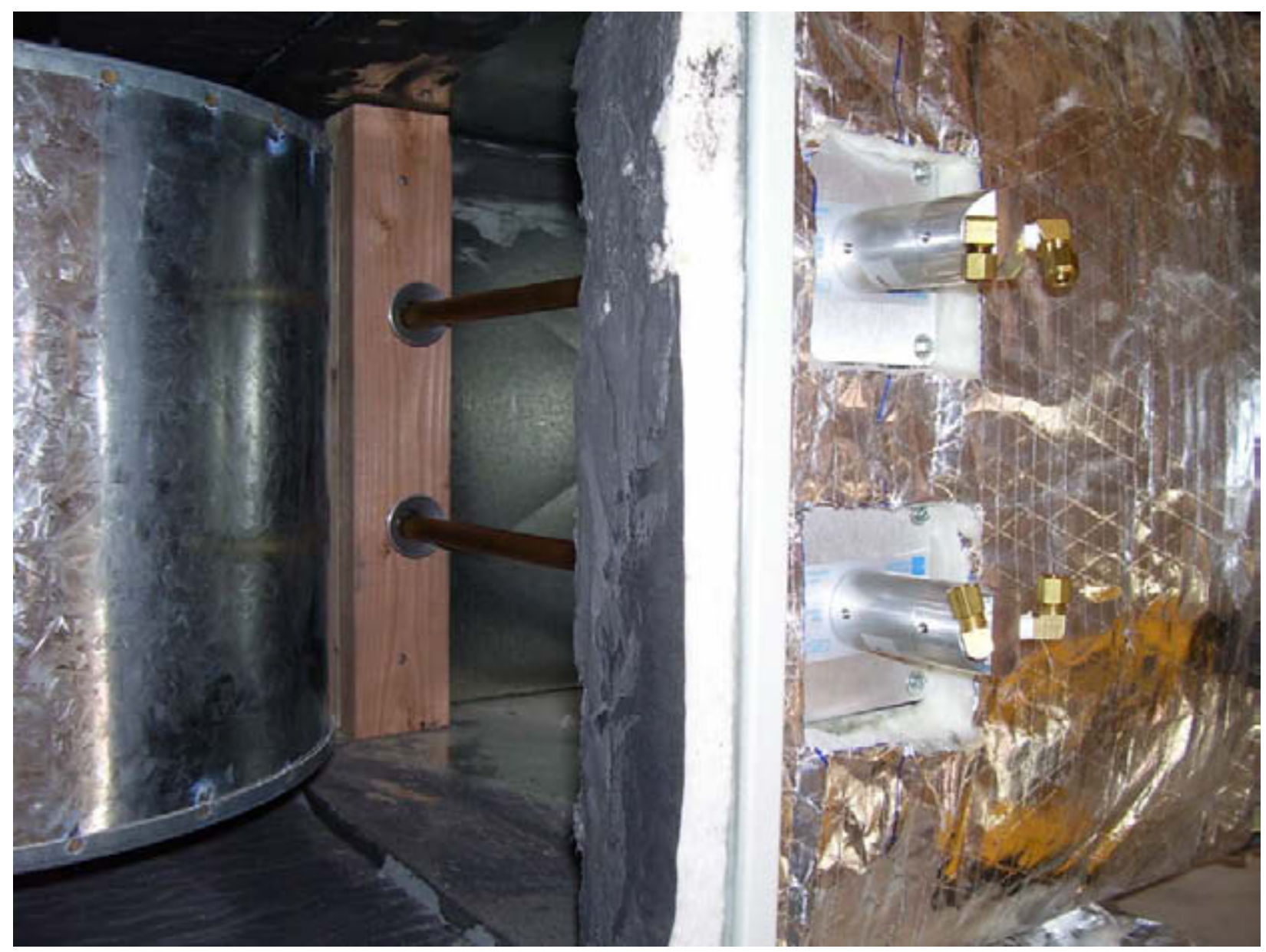

Figure 23. Pitot tube traverse airflow sensors installed at the return duct for the DiGiorgio home

Unfortunately, the installed return duct dimensions were not inline with the specified duct dimension, and the airflow sensors were ordered according to design specification for the return duct system. When the time came for the installation, the sensors were too short. The addition of the $2 \times 4$ blocks above allowed the sensors to be installed; however, the accuracy of the sensors

\footnotetext{
${ }^{7}$ The Nightbreeze AH is a product of DEG that incorporates an outdoor air damper for a night ventilation cooling ability as well as an outdoor air ventilation capability, for more on Nightbreeze see www.davisenergy.com/nb_page.html.
} 
is now very questionable as a result of the change in cross-sectional area for the duct. In addition, at the lowest flow rate provided by the Nightbreeze, air velocities of roughly 70 FPM are realized, which is nearly impossible to measure with a pressure-based sensor such as the pitot tube traverse probes that were initially installed at the DiGiorgio home. Engineers at DEG and NREL discussed alternatives to make the airflow measurement at DiGiorgio and considered ordering the correct-length Pitot type sensors. However, that option was discarded because of the lack of adequate airflow development length, as illustrated in Figure 24 and close proximity to the air handler fan as shown in Figure 23.

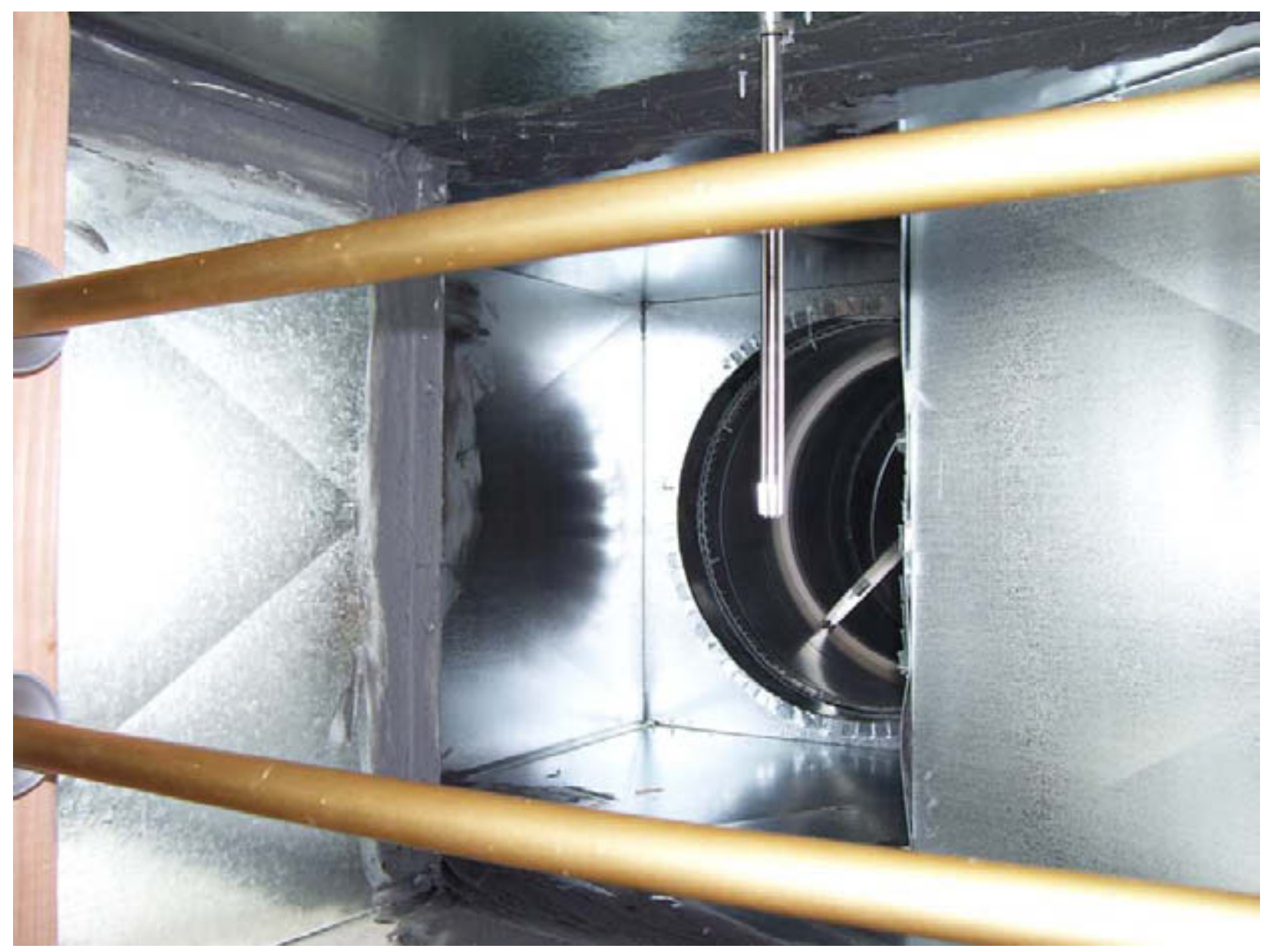

Figure 24. Illustration of the non-uniform return duct and close proximity of Pitot tube traverse airflow sensors to outdoor air damper and return register assembly.

Because of the duct arrangement at the DiGiorgio home, this location was identified as the only possible location where airflow sensors could be installed. The primary advantage to this location was that the AH filter was to be installed directly in front of the airflow sensors (installation of the filter was not complete at the time this photo was taken) and would act as an airflow straightener. In order to measure the airflow continuously across the manufacturer's specified airflow operating range (200-2000 CFM), we decided that fan RPM will be directly measured from the fan motor pulse output and will be mapped against a fan-assisted flow hood 
to establish supply air flow rates as a function of fan RPM. Datalogger programs will be revised to reflect the RPM signal from the fan motor in order to cover the range of continuously variable airflow rates that the Nightbreeze unit is capable of providing. NREL will perform the mapping of the fan RPM vs. known fan flow rates during a site visit in the summer of 2006. Capacity for the unit running in air-conditioning mode will be determined by the change in enthalpy of the supply- and return-air conditions and the supply-air flow rate. Measured values from the Table 6 will be used in the calculations of enthalpy and cooling-system capacity. Cooling-system capacity coupled with the electrical energy measurements for the unit will allow use to calculate an EER for the unit.

Establishing outdoor dry-bulb temperatures is accomplished with two type-T thermocouples installed in a custom-built forced-aspiration radiation shield. The absolute humidity of outdoor air is established by using a Vaisala HMP-50 temperature and RH sensor installed in a naturally aspirated plate-style radiation shield. Temperature and $\mathrm{RH}$ data from this sensor are used to determine the absolute humidity of air, which is logged as part of the datalogger program, the installation is shown in Figure 25.

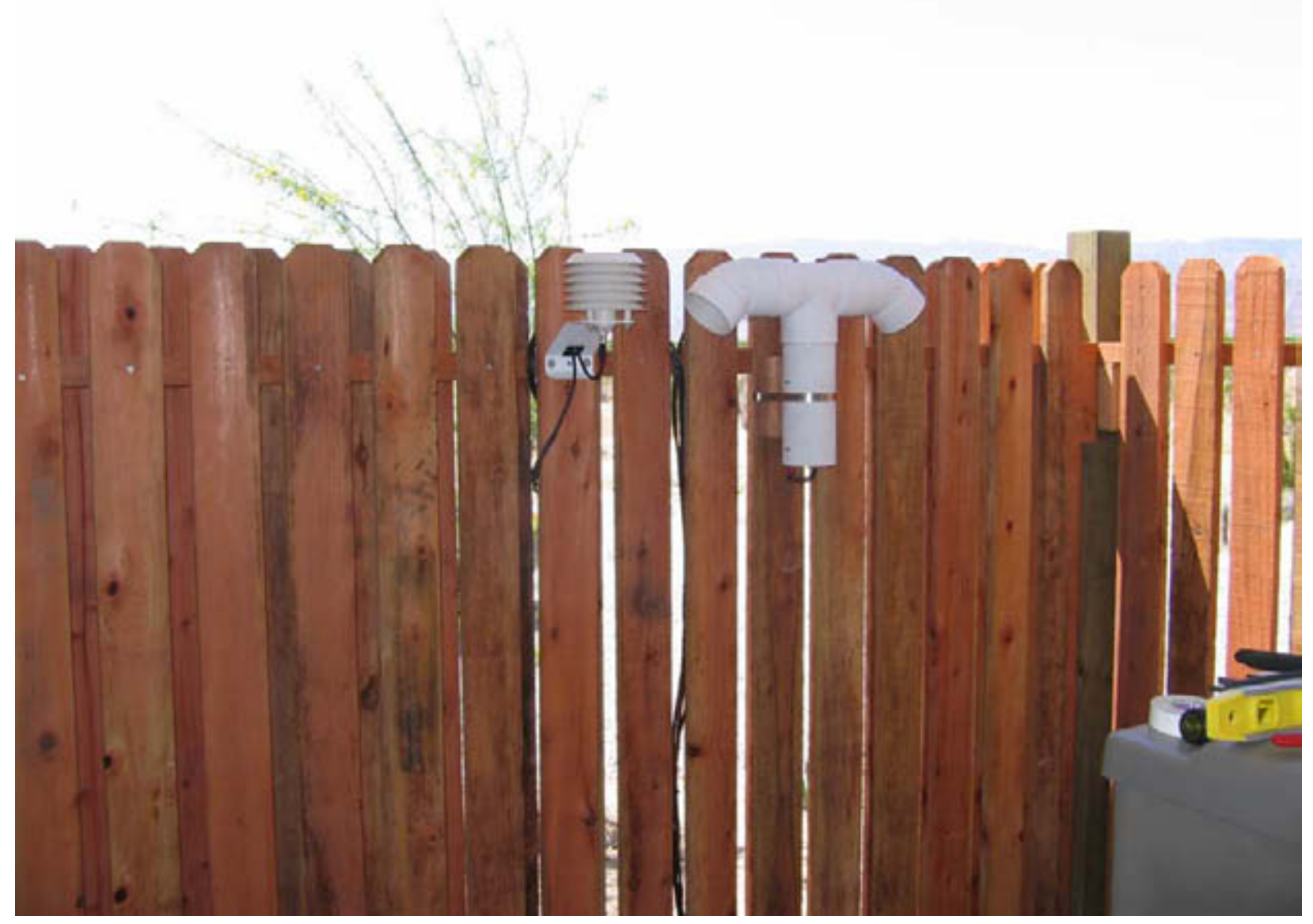

Figure 25. Vaisala temperature and RH sensors (left in plate shield) and custom forcedaspiration radiation shield with thermocouples (right, white PVC) installed at fence surrounding Freus condensing unit 
The performance of the evaporative-cooled Freus condensing unit is not well known. In order to establish the performance of the condenser, NREL staff is attempting to measure the heat rejected by the condensing unit via airside measurements. For the condenser fan intake and exhaust air conditions, dry-bulb temperatures are measured with type-T thermocouples and absolute humidity is calculated from Vaisala HMP-45A temperature and RH sensors. At the intake and exhaust grills for the condenser support, six thermocouples are attached in parallel for the dry-bulb measurements. At the condenser inlet, the Vaisala temperature and RH sensor is installed in a custom shield (designed to prevent water from the sump from damaging the sensor) located behind the condenser intake grill. At the condenser exhaust grill a second Vaisala HMP45A sensor is used in conjunction with a sampling tube laid on top of the exhaust grill. Exhaust air is sampled through multiple holes drilled into the tube and is pulled past the Vaisala sensor by a vacuum pump that is mounted on the electrical box that contains the watt-hour transducers for the absolute humidity calculations. Figures 26 and 27 show the arrangement of the sensors on Freus condensing unit.

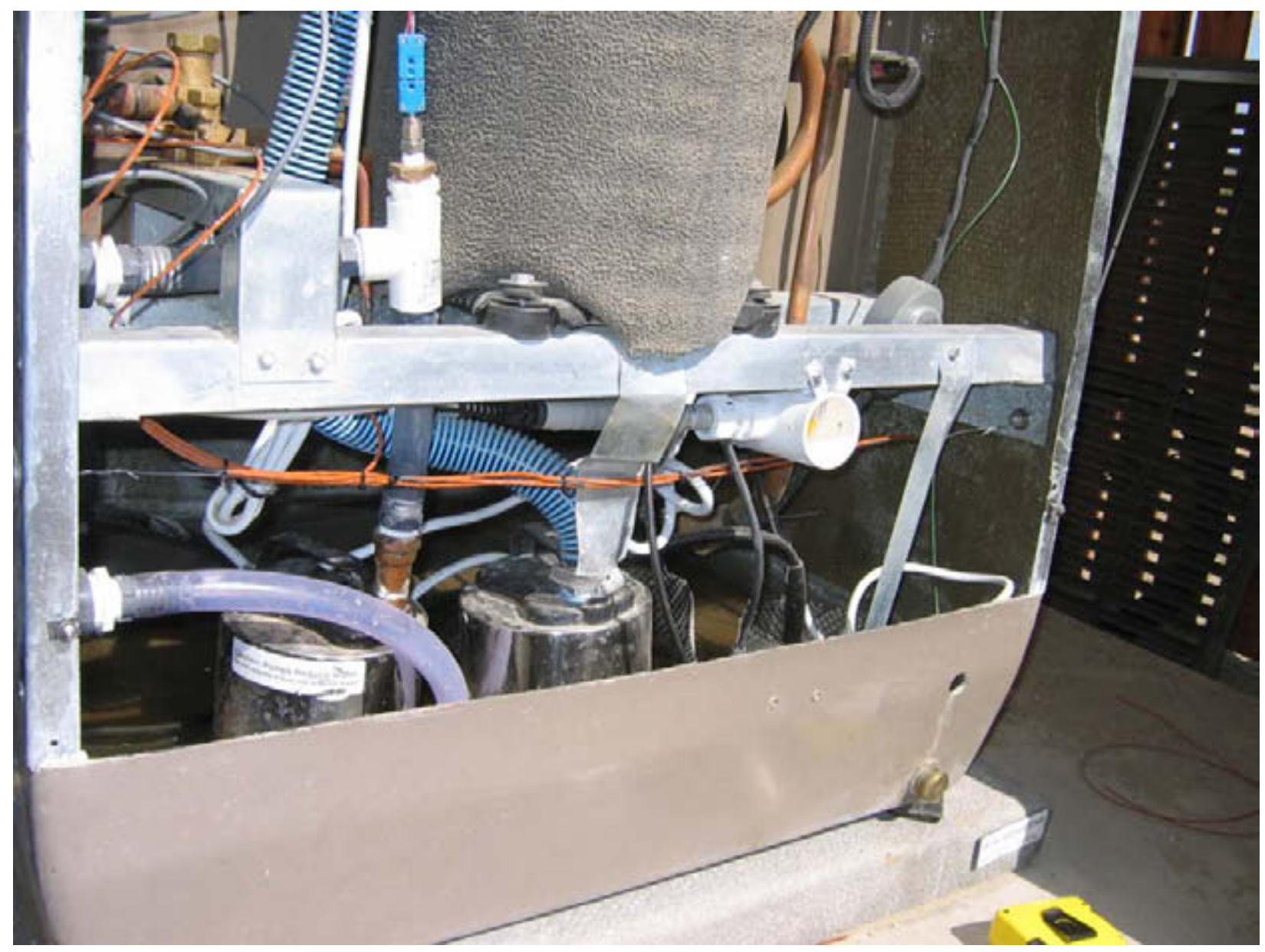

Figure 26. Thermocouple (brown wire) and Vaisala temperature and RH sensors (white PVC shield + gray sensor) installed at Freus air intake, grill removed 


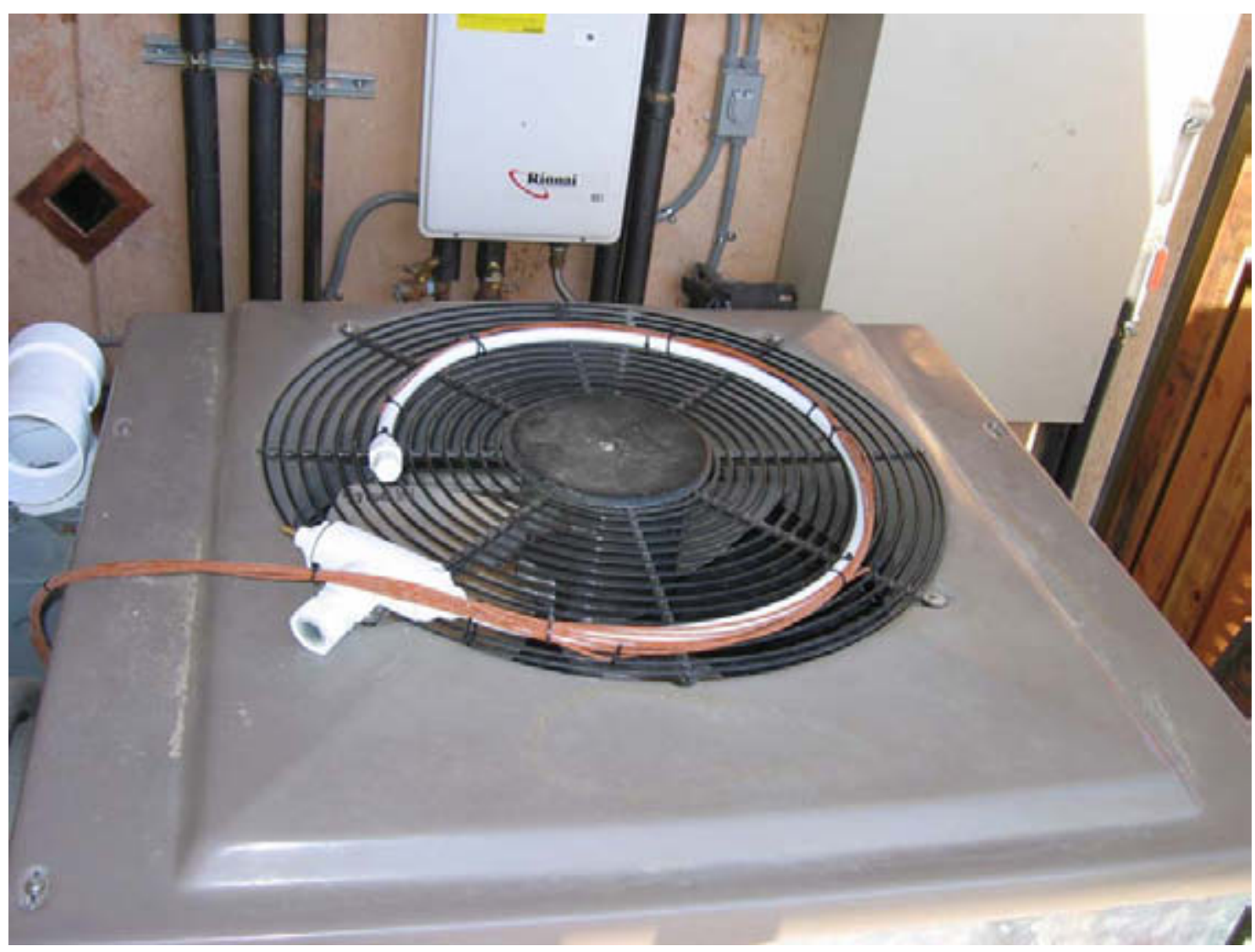

Figure 27. Thermocouple (brown wire) and sampling tube (white PVC shield plus white tube) installed at Freus exhaust grill. Vacuum pump housing shown on left (White PVC pipe fitting)

Airflow rate for the Freus condensing unit was established by using a fan-assisted flow-hood arrangement that utilized a blower-door fan. Because the condenser fan is a single-speed unit, a one-time measurement of the condenser fan flow rate was judged to be appropriate given the difficulties in making a continuous measurement of the fan flow rate. Figure 28 shows the installation of the fan-assisted flow hood. 


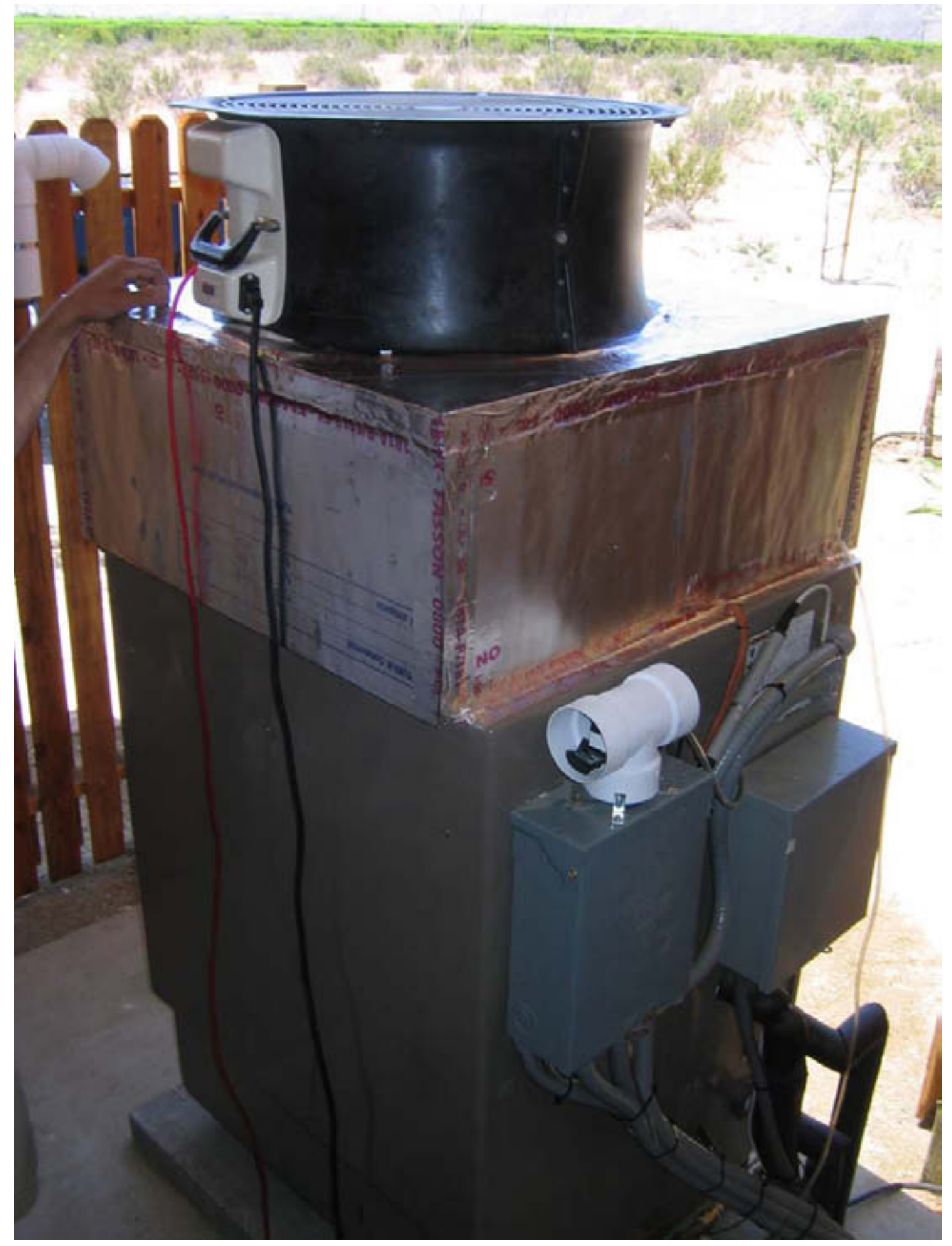

Figure 28. Fan-assisted flow hood installed on the Freus unit 
A blower-door fan was used to determine the condenser fan flow rate by adjusting the blowerdoor fan RPM until the measured pressure difference across the foil-faced foam-board box was zeroed using the manometer gauge typically used with a blower door while the condenser fan was running. When the pressure difference inside the foil-faced foam-board box compared to ambient went to zero, the flow rate coincident with pressure measured at the pressure tap on the blower-door fan was established from manufacturer's literature for the blower-door fan according to the flow ring installed on the blower-door fan. The use of the blower-door fan to make this measurement very closely resembles using a duct-blaster fan as a "powered capture hood" as described in Chapter 13 of the duct blaster manual (www.energyconservatory.com/download/dbmanual.pdf).

However, a duct blaster was not used in this application because a duct blaster fan is not capable of achieving the flow rate necessary to zero the pressure difference across the foam-board box. This method showed the condenser fan flow rate to be 1490 CFM. The energy use of the condenser fan and compressor are sub-metered for the Freus in an effort to develop a component model of the Freus evaporatively cooled condenser for use with whole-buildings simulation tools. Currently no such model exists in typical residential annual hourly whole-building simulation tools.

\subsubsection{Freus Performance Data Results from Magna}

Real-time measurements of the Freus system were taken by SWA/CARB with a portable data logger on September 29, 2004. There are no plans to add permanent instrumentation to this house because it is currently occupied and adding instrumentation would be too disruptive to the occupants. At the time, ambient conditions were mild with an outside air temperature of about $70^{\circ} \mathrm{F}$. The measured EER of the Freus was only 6.6 , which was much lower than expected. It was concluded in a February 4, 2005, report by SWA/CARB that there must have been an installation problem with the indoor evaporation coil. SWA and NREL staff returned to take additional test data in August 2005.

As a result of a second site visit to the homes at Magna, Utah, in early August 2005, the Freus unit was found to be undercharged. A local HVAC technician added $6.5 \mathrm{lbs}$ of R-22 refrigerant after pulling a vacuum on the system and repairing a kink in the refrigerant line. Freus engineers were consulted and had the expectation that a properly charged unit would see about $6^{\circ} \mathrm{F}-10^{\circ} \mathrm{F}$ of sub-cooling and $8^{\circ} \mathrm{F}-15^{\circ} \mathrm{F}$ of superheat. After the refrigerant was added, about $6^{\circ} \mathrm{F}-7^{\circ} \mathrm{F}$ of subcooling and $10^{\circ} \mathrm{F}$ of superheat were achieved. Line pressures were about $160 \mathrm{psi}$ on the highpressure side and 78 psi on the low-pressure side.

Field measurements of the air-handler fan flow rates were made with a Trueflow plate. ${ }^{8}$ Temperature and RH were evaluated with Humerel temperature and RH sensors. Energyconsumption measurements were performed with a handheld GREENLEE power meter. Airhandler fan flows were adjusted by altering the jumper configuration on the furnace circuit board.

\footnotetext{
${ }^{8}$ www.energyconservatory.com/products/products6.htm
} 
Initial data collected on the Freus unit at Magna showed that making repairs and adding the refrigerant greatly improved performance. Figure 29 shows the capacity obtained at two different fan speeds. Table 7 shows the results of specific measurements taken at two different fan speeds at an outdoor condition of $90^{\circ} \mathrm{F}$ dry bulb $/ 69^{\circ} \mathrm{F}$ wet bulb and a return-air condition of $81.3^{\circ} \mathrm{F}$ dry bulb $/ 66.3^{\circ} \mathrm{F}$ wet bulb. It lists the various power levels that were measured with a GREENLEE ${ }^{9}$ CMP-200 Power Clamp (true RMS reading), the corresponding power factors (PF), the capacities, and the energy efficiency ratio. The EER was measured as 13.3 at the low flow rate (400 CFM per ton) and 13.7 at the high flow rate (500 CFM per ton). Freus has not been able to provide us with an EER rating with the particular 3-ton evaporator coil used at Magna. However, the average EER rating for a range of 2-ton coils was 14.1 from the manufacturer's data. This rating was for an outdoor condition of $95^{\circ} \mathrm{F}$ dry bulb $/ 75^{\circ} \mathrm{F}$ wet bulb and an indoor condition of $80^{\circ} \mathrm{F}$ dry bulb $/ 67^{\circ} \mathrm{F}$ wet bulb.

The indoor conditions for the Magna measurement were very close to the specification conditions. The outdoor conditions were a little more favorable than the specification conditions. Because of this and because Unit \#2 uses a 3-ton evaporator coil instead of a 2-ton coil, one would expect the measured EER to be somewhat higher than the specification, whereas it is actually a little lower. At Borrego Springs, we should have specification data appropriate to the indoor coil and will be able to make a fairer comparison between measurement and specification.

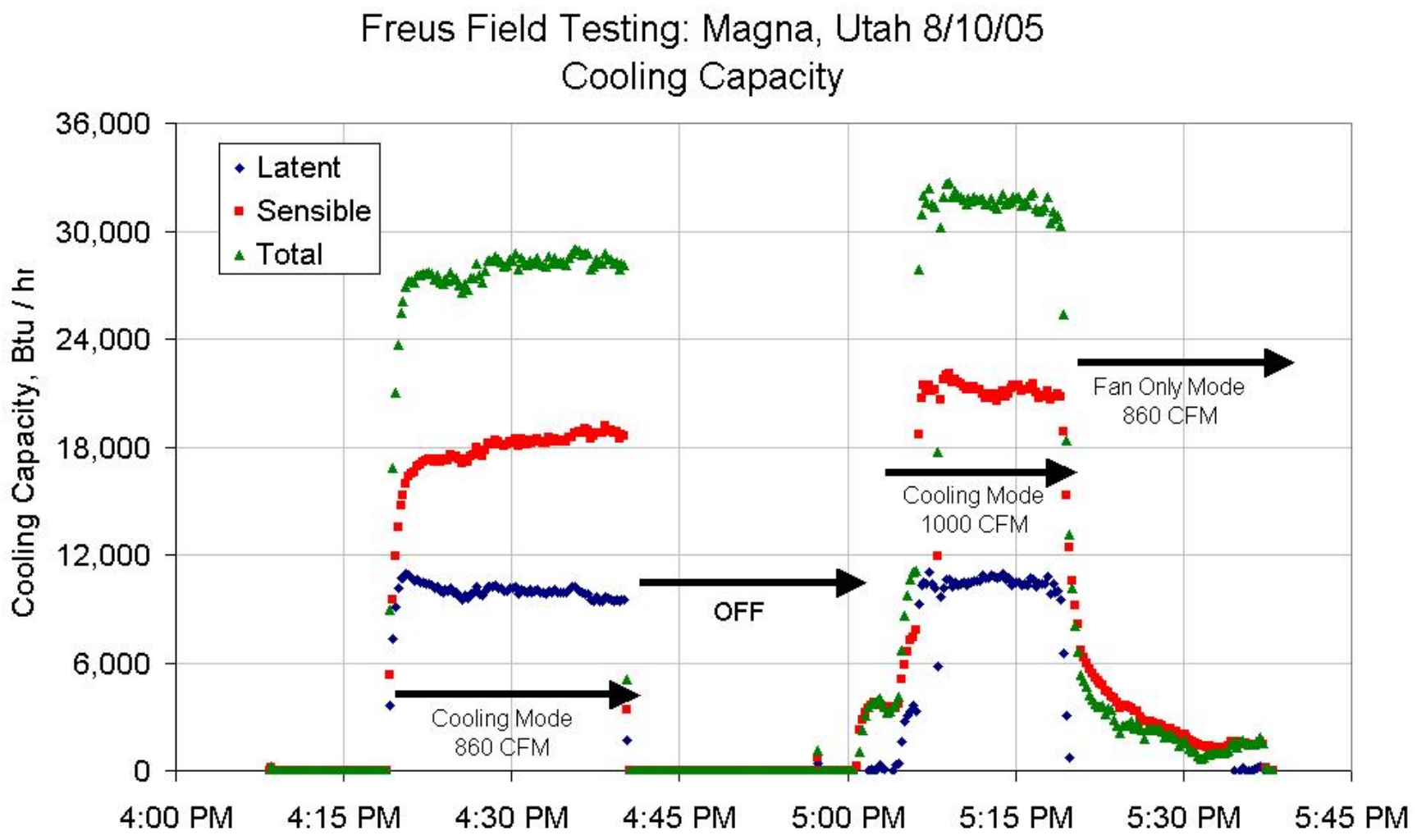

Figure 29. Measurements taken at Magna, Utah, showing the sensible, latent, and total cooling capacities of the Freus unit at two different fans speeds on August 10, 2005

${ }^{9}$ www.greenlee.com 

Table 7. Measurement Results for Freus Unit at Magna
after Refrigerant was Added

\begin{tabular}{cccccccc}
\hline Fan Mode & $\begin{array}{c}\text { Freus } \\
\text { Watts }\end{array}$ & $\begin{array}{c}\text { Freus } \\
\text { PF }\end{array}$ & $\begin{array}{c}\text { Fan } \\
\text { Watts }\end{array}$ & $\begin{array}{c}\text { Fan } \\
\text { PF }\end{array}$ & $\begin{array}{c}\text { Total } \\
\text { Watts }\end{array}$ & $\begin{array}{c}\text { Capacity } \\
\text { (Btu/hr) }\end{array}$ & EER \\
\hline 400 CFM per ton & 1,850 & 1.00 & 290 & 0.62 & 2,140 & 28372 & 13.3 \\
500 CFM per ton & 1,870 & 1.00 & 450 & 0.63 & 2,320 & 31739 & 13.7 \\
\hline
\end{tabular}

\subsection{Summary and Conclusions}

Field measurements of the overall performance of the Freus and OASys cooling systems at Magna indicate that they are performing close to expectations. Monitoring plans have been developed for the forthcoming Borrego Springs installations that will allow us to take more detailed data on these systems. DOE-2 annual simulations for a number of cities showed that the Freus provides a significant improvement over a conventional DX system in dry climates and does not have any negative impact on indoor comfort conditions. The OASys and conventional evaporative cooler provide more significant reductions in cooling energy use. However, both the OASys and, especially, the direct evaporative cooler can compromise indoor comfort conditions during humid periods. For such situations they may require a parallel DX unit to maintain comfort and this would incur additional capital cost. The OASys will provide reasonable indoor comfort for a wider range of locations than the direct evaporative cooler.

\subsection{References}

Eastment, M., E. Hancock, and C. Kutscher. 2005. "Projected Costs and Benefits of New Residential Evaporative Cooling Systems," Golden, CO: National Renewable Energy Laboratory.

\footnotetext{
${ }^{10} 90^{\circ} \mathrm{F}_{\mathrm{DB}} / 69^{\circ} \mathrm{F}_{\mathrm{WB}}$ outdoor, $81.3^{\circ} \mathrm{F}_{\mathrm{DB}} / 66.3^{\circ} \mathrm{F}_{\mathrm{WB}}$ return air, one-time power measurements with GREENLEE CMP200 Power Clamp (True RMS)
} 


\section{Appendix A. OASys Technical Specifications}

Electronic Features

Thermostat

Control System

multi-function electronic

proprietary firmware

3/4-hp variable-speed GE ECM2.3

Cooling Capacity, Btu/h ${ }^{11}$

Unducted Installation $\quad 20,700$

Ducted Installation $\quad 19,300$

$\begin{array}{lll}\text { Airflow Features } & \text { Unducted } & \begin{array}{l}\text { Ducted }^{\mathbf{1 2}} \\ \text { Supply maximum }\end{array} \\ \text { Exhaust maximum }^{13} & 550 & 1350 \\ & 550 & 850\end{array}$

\section{Electrical Characteristics}

Voltage

$115 / 1$

Power, max $\quad 1.2 \mathrm{~kW}$

Unit FLA $\quad 10.5$ Amps

Evaporative Media

Direct cooling stage

Munter's CELdek ${ }_{\circledast} 5090$

Indirect cooling stage Speakman polymer parallel plate

\section{Dimensions and weight}

$\mathrm{W} \times \mathrm{D} \times \mathrm{H}$, inches

Unit weight

Operating weight

$\begin{array}{ll}\text { Cased } & \text { Uncased } \\ 29 \times 24 \times 78 & 27 \times 22 \times 66 \\ 190 \mathrm{lbs} & 120 \mathrm{lbs} \\ 240 \mathrm{lbs} & 170 \mathrm{lbs}\end{array}$

\section{Water consumption}

Reservoir size

5 gallons

Rate of evaporation

6-11 gallons per hour

Rated at Sacramento design conditions

120.2 inches external static pressure

13 airflow restrictions imposed by ducts, grilles, or inadequate venting of air from the house causes an increase in exhaust air and reduction in supply air

\section{Configuration Types}

Uncased:

Wall mount

Cased: Roof mount, portable

\section{Connections \\ Thermostat \\ Water fill \\ RJ45 \\ $1 / 2$-in. NPT \\ Drain \\ barbed hose \\ Electrical \\ 115-V AC terminals}

Photovoltaic integration

$300-V$ DC to motor blends seamlessly with 115-V AC

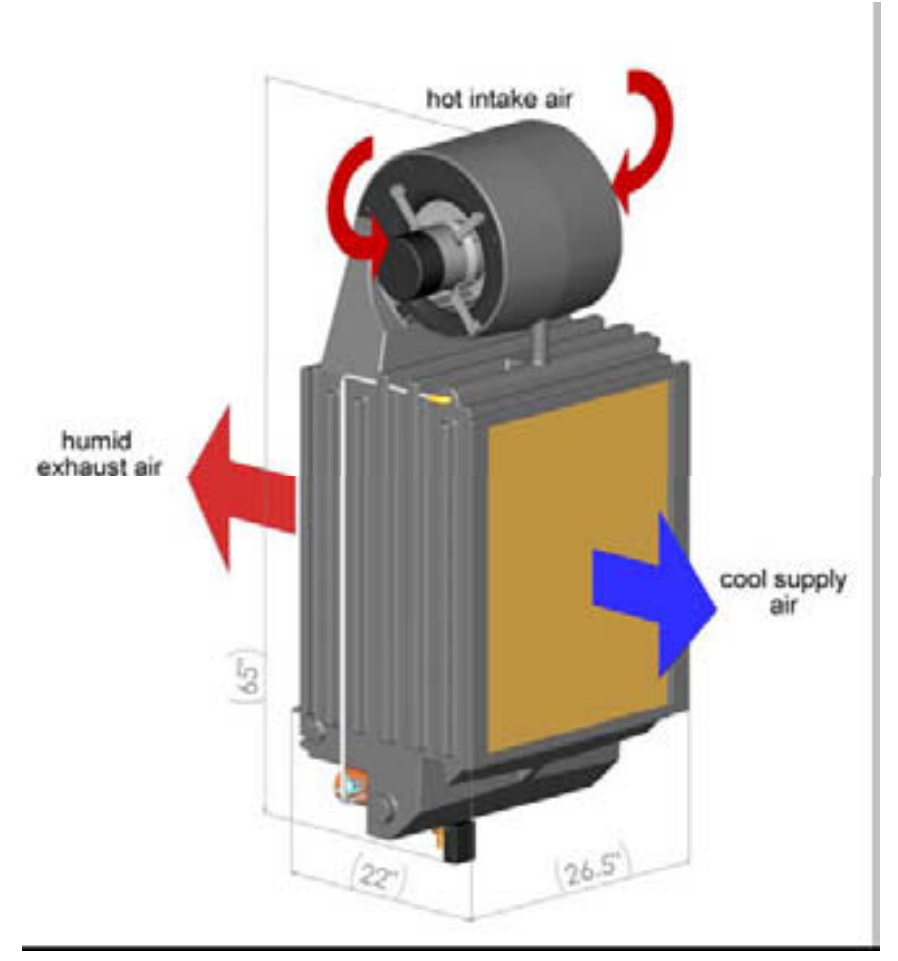


OASys Components at a glance

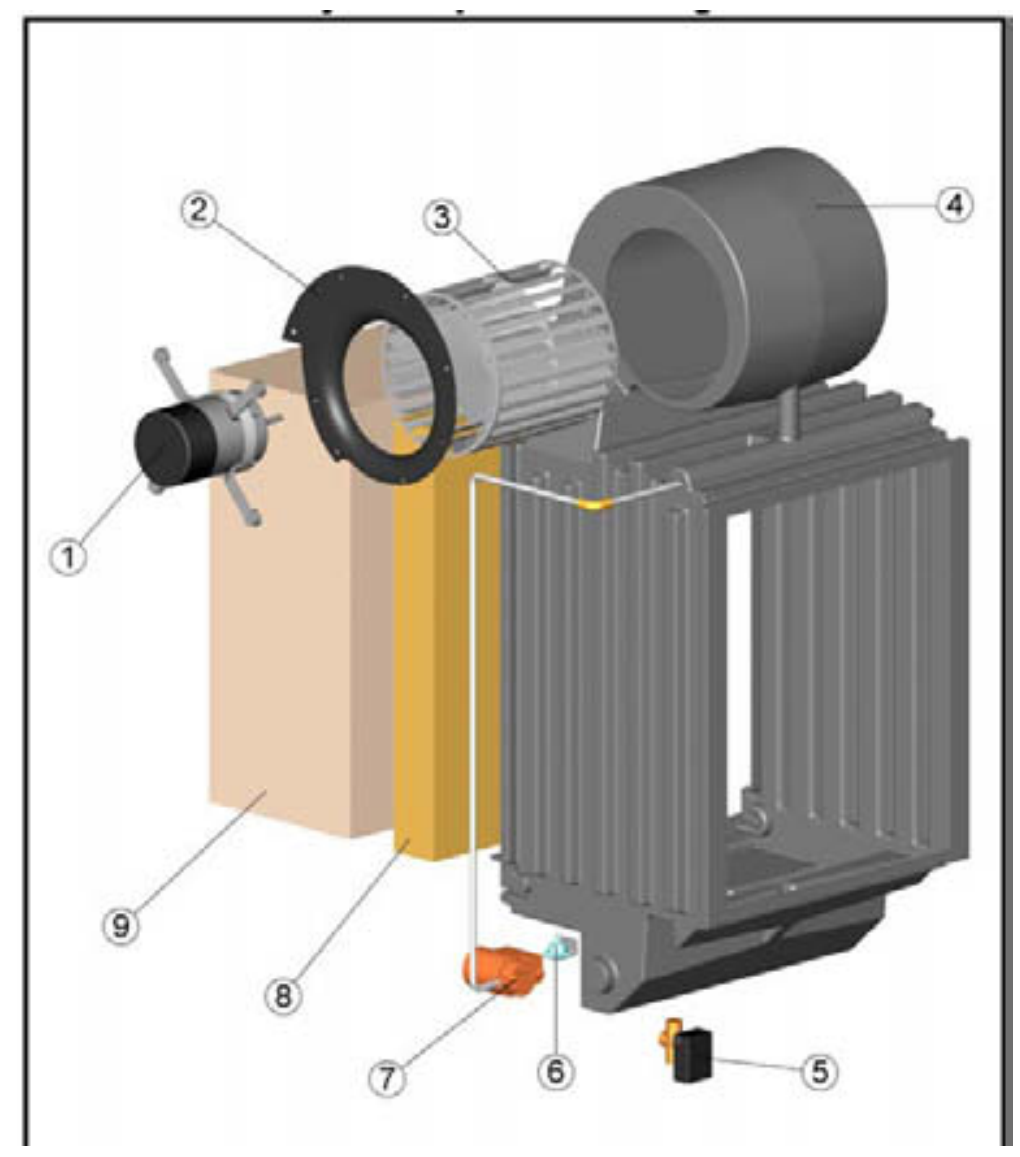

1. $3 / 4$-hp GE ECM2.3 Electronically Commutated Motor

2. Venturi mounting plate

3. Morrison 11-11 squirrel-cage blower wheel

4. Polyethylene rotationally molded cabinet

5. Drain valve

6. Fill valve

7. Taco 003 water circulator

8. Munter's CELdek $\circledast 5090$ direct cooling stage

9. Speakman indirect cooling stage 


\section{OASys Performance Characteristics}

\begin{tabular}{|c|c|c|c|c|c|}
\hline \multirow{2}{*}{ Installation Type } & \multicolumn{3}{|c|}{ Unducted } & \multicolumn{2}{|c|}{ Ducted } \\
\hline & $\begin{array}{l}\text { High } \\
\text { Speed }\end{array}$ & $\begin{array}{c}\text { Medium } \\
\text { Speed }\end{array}$ & $\begin{array}{l}\text { Low } \\
\text { Speed }\end{array}$ & $\begin{array}{l}\text { High } \\
\text { Speed }\end{array}$ & $\begin{array}{l}\text { Low } \\
\text { Speed }\end{array}$ \\
\hline Fan Power, Watts & 498 & 266 & 58 & 445 & 110 \\
\hline Total Power, Watts & 521 & 289 & 81 & 468 & 133 \\
\hline Supply cfm & 1551 & 1251 & 750 & 1250 & 750 \\
\hline $\begin{array}{l}\text { Secondary cfm (indirect } \\
\text { section exhaust) }\end{array}$ & 622 & 478 & 250 & 800 & 490 \\
\hline Entering Air Dry Bulb, ${ }^{\circ} \mathrm{F}$ & 104.7 & 103.7 & 104.3 & 103.1 & 106.5 \\
\hline Entering Air Wet Bulb, ${ }^{\circ} \mathrm{F}$ & 70.8 & 71.1 & 73.0 & 73.3 & 74.3 \\
\hline Between stage Dry Bulb, ${ }^{\circ} \mathrm{F}$ & 87.0 & 85.0 & 84.5 & 80.5 & 82.9 \\
\hline Leaving Air Dry Bulb, ${ }^{\circ} \mathrm{F}$ & 67.8 & 67.8 & 68.8 & 68.7 & 69.1 \\
\hline Leaving Air Wet Bulb, ${ }^{\circ} \mathrm{F}$ & 65.0 & 65.3 & 67.2 & 66.6 & 67.5 \\
\hline Indirect Effectiveness, \% & 52.2 & 57.2 & 63.3 & 75.7 & 73.3 \\
\hline Direct Effectiveness, \% & 87.1 & 87.4 & 91.0 & 84.8 & 89.6 \\
\hline Total Effectiveness, \% & 108.9 & 110.1 & 113.6 & 115.3 & 116.2 \\
\hline Capacity, Btu/hr* & 20,660 & 17,155 & 11,128 & 19,257 & 11,770 \\
\hline Capacity, tons* & 1.72 & 1.43 & 0.93 & 1.60 & 0.98 \\
\hline EER* $^{*}$ & 40 & 59 & 136 & 41 & 88 \\
\hline
\end{tabular}

* Capacity and EER are calculated using design conditions for Sacramento: $101^{\circ} \mathrm{F} \mathrm{db} / 70^{\circ} \mathrm{F}$ wb and an indoor temperature of $80^{\circ} \mathrm{F}$. 
For more information, contact

Covington Stanwick

Speakman CRS

P.O. Box 191

Wilmington, Delaware 19899 USA

Ph: 301.643 .4115

Fax: 302.765 .0286 


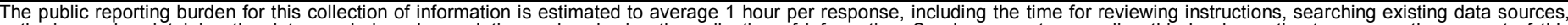

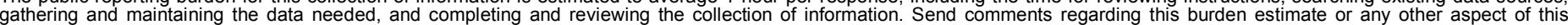

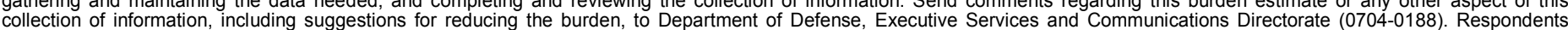

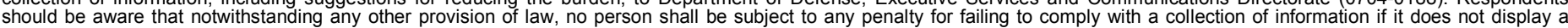

chould be aware that notwithstandin

PLEASE DO NOT RETURN YOUR FORM TO THE ABOVE ORGANIZATION.

\begin{tabular}{l|l|l|} 
1. REPORT DATE $(D D-M M-Y Y Y Y)$ & 2. REPORT TYPE & 3. DATES COVERED (FrOm - TO)
\end{tabular}

October 2006

Technical Report

4. TITLE AND SUBTITLE
Projected Benefits of New Residential Evaporative Cooling

Systems: Progress Report \#2

5a. CONTRACT NUMBER

DE-AC36-99-GO10337

5b. GRANT NUMBER

5c. PROGRAM ELEMENT NUMBER

5d. PROJECT NUMBER

NREL/TP-550-39342

5e. TASK NUMBER

BET6.8004

5f. WORK UNIT NUMBER
7. PERFORMING ORGANIZATION NAME(S) AND ADDRESS(ES)

National Renewable Energy Laboratory

1617 Cole Blvd.

Golden, CO 80401-3393

9. SPONSORING/MONITORING AGENCY NAME(S) AND ADDRESS(ES)
8. PERFORMING ORGANIZATION REPORT NUMBER

NREL/TP-550-39342

10. SPONSOR/MONITOR'S ACRONYM(S) NREL

11. SPONSORING/MONITORING AGENCY REPORT NUMBER

12. DISTRIBUTION AVAILABILITY STATEMENT

National Technical Information Service

U.S. Department of Commerce

5285 Port Royal Road

Springfield, VA 22161

13. SUPPLEMENTARY NOTES

14. ABSTRACT (Maximum 200 Words)

The use of conventional evaporative cooling has rapidly declined in the United States despite the fact that it has high potential for energy savings in dry climates. Evaporative systems are very competitive in terms of first cost and provide significant reductions in operating energy use, as well as peak-load reduction benefits. Significant market barriers still remain and can be addressed through improved systems integration. This report investigates the first of these approaches, exploring innovative components. The U.S. Department of Energy (DOE) Building America research teams are investigating the use of two promising new pieces of residential cooling equipment that employ evaporative cooling as a part of their system design. The OASys unit, which is a combination of direct and indirect evaporative cooling stages developed by Davis Energy Group (DEG) and manufactured by Speakman CRS, is used to ultimately provide outside air to the living space. The outdoor air provided is indirectly and directly evaporatively cooled in two stages to a condition that can be below the wet-bulb (wb) temperature of the outside air, thus outperforming a conventional single-stage direct evaporative cooler.

\section{SUBJECT TERMS}

Building America; U.S. Department of Energy; evaporative cooling; energy savings; residential buildings; peak-load reduction; residential cooling equipment

\begin{tabular}{|c|c|c|c|c|}
\hline \multicolumn{3}{|c|}{ 16. SECURITY CLASSIFICATION OF: } & \multirow{2}{*}{$\begin{array}{l}\text { 17. LIMITATION } \\
\text { OF ABSTRACT } \\
\text { UL }\end{array}$} & \multirow{2}{*}{$\begin{array}{ll}\text { 18. } & \text { NUMBER } \\
\text { OF PAGES }\end{array}$} \\
\hline $\begin{array}{l}\text { a. REPORT } \\
\text { Unclassified }\end{array}$ & $\begin{array}{l}\text { b. ABSTRACT } \\
\text { Unclassified }\end{array}$ & $\begin{array}{l}\text { c. THIS PAGE } \\
\text { Unclassified }\end{array}$ & & \\
\hline
\end{tabular}

19a. NAME OF RESPONSIBLE PERSON

19b. TELEPHONE NUMBER (Include area code) 


\section{A Strong Energy Portfolio for a Strong America}

Energy efficiency and clean, renewable energy will mean a stronger economy, a cleaner environment, and greater energy independence for America. Working with a wide array of state, community, industry, and university partners, the U.S. Department of Energy's Office of Energy Efficiency and Renewable Energy invests in a diverse portfolio of energy technologies.

\section{Research and Development of Buildings}

Our nation's buildings consume more energy than any other sector of the U.S. economy, including transportation and industry. Fortunately, the opportunities to reduce building energy useand the associated environmental impacts—are significant.

DOE's Building Technologies Program works to improve the energy efficiency of our nation's buildings through innovative new technologies and better building practices. The program focuses on two key areas:

\section{- Emerging Technologies} Research and development of the next generation of energy-efficient components, materials, and equipment

- Technology Integration Integration of new technologies with innovative building methods to optimize building performance and savings

For more information contact: EERE Information Center 1-877-EERE-INF (1-877-337-3463) www.eere.energy.gov

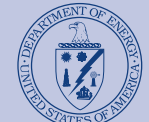

U.S. Department of Energy Energy Efficiency and Renewable Energy

An electronic copy of this publication is available on the Building America Web site at www.buildingamerica.gov

\section{Visit our Web sites at:}

\section{www.buildingamerica.gov}

www.pathnet.org

www.energystar.gov

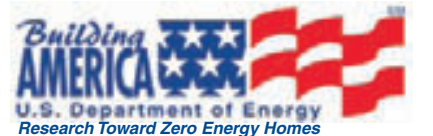

Research Toward Zero Energy Homes

Building America Program

George S. James • New Construction • 202-586-9472• fax: 202-586-8134• e-mail: George.James@ee.doe.gov Terry Logee • Existing Homes • 202-586-1689 • fax: 202-586-4617• e-mail: terry.logee@ee.doe.gov Lew Pratsch • Integrated Onsite Power • 202-586-1512 • fax: 202-586-8185• e-mail: Lew.Pratsch@hq.doe.gov Building America Program • Office of Building Technologies, EE-2J • U.S. Department of Energy • 1000 Independence Avenue, S.W. • Washington, D.C. 20585-0121・ www.buildingamerica.gov

Building Industry Research Alliance (BIRA)

Robert Hammon • ConSol • 7407 Tam 0'Shanter Drive \#200 • Stockton, CA 95210-3370 • 209-473-5000 • fax: 209-474-0817• e-mail: Rob@consol.ws•www.bira.ws

\section{Building Science Consortium (BSC)}

Betsy Pettit • Building Science Consortium (BSC) • 70 Main Street • Westford, MA $01886 \bullet 978-589-5100 \bullet$ fax: 978-589-5103• e-mail: Betsy@buildingscience.com • www.buildingscience.com

Consortium for Advanced Residential Buildings (CARB)

Steven Winter • Steven Winter Associates, Inc. • 50 Washington Street • Norwalk, CT $06854 \bullet 203-857-0200 \bullet$ fax: 203-852-0741 • e-mail: swinter@swinter.com•www.carb-swa.com

\section{Davis Energy Group}

David Springer • Davis Energy Group • 123 C Street • Davis, CA 95616 • 530-753-1100 • fax: 530-753-4125 • e-mail: springer@davisenergy.com • deg@davisenergy.com・www.davisenergy.com/index.html

\section{IBACOS Consortium}

Brad Oberg •IBACOS Consortium • 2214 Liberty Avenue • Pittsburgh, PA $15222 \bullet 412-765-3664 \bullet$ fax: 412-765-3738 • e-mail: boberg@ibacos.com • www.ibacos.com

Industrialized Housing Partnership (IHP)

Subrato Chandra • Florida Solar Energy Center • 1679 Clearlake Road • Cocoa, FL 32922 • 321-638-1412 • fax: 321-638-1439 • e-mail: subrato@fsec.ucf.edu•www.baihp.org

National Association of Home Builders (NAHB) Research Center

Tom Kenney • National Association of Home Builders (NAHB) Research Center • 400 Prince George's Boulevard • Upper Marlboro, MD 20774 • 301-430-6246 • fax: 301-430-6180 • toll-free: 800-638-8556• www.nahbrc.org/

\section{National Renewable Energy Laboratory}

Ren Anderson • 1617 Cole Boulevard, MS-2722 • Golden, C0 80401 • 303-384-7433 • fax: 303-384-7540 •

e-mail: ren_anderson@nrel.gov • www.nrel.gov

Tim Merrigan • 1617 Cole Boulevard, MS-2722 • Golden, C0 80401 • 303-384-7349 • fax: 303-384-7540 • e-mail: tim_merrigan@nrel.gov•www.nrel.gov

\section{Oak Ridge National Laboratory}

Pat M. Love • P.0. Box $2008 \bullet$ One Bethel Valley Road • Oak Ridge, TN $37831 \bullet 865-574-4346 \bullet$ fax: 865-574-9331 • e-mail: lovepm@ornl.gov・www.ornl.gov

Produced for the U.S. Department of Energy (DOE) by the National Renewable Energy Laboratory, a DOE national laboratory. October 2006 • NREL/TP-550-39342

Printed with a renewable-source ink on paper containing at least $50 \%$ wastepaper, including $10 \%$ postconsumer waste. 